Labor in the Boardroom

Simon Jäger, Benjamin Schoefer, and Jörg Heining

NBER Working Paper No. 26519

November 2019, Revised August 2020

JEL No. G3,K31,J0,J3,J53,J54,M12,M5

\begin{abstract}
We estimate the wage effects of shared governance, or codetermination, in the form of a mandate of one third of corporate board seats going to worker representatives. We study a reformin Germany that abruptly abolished this mandate for stock corporations incorporated after August 1994, while it locked the mandate for the slightly older cohorts. Our research design compares firm cohorts incorporated before the reform and after; in a robustness check we additionally draw on the analogous difference in unaffected firm types (LLCs). We find no effects of board-level codetermination on wages and the wage structure, even in firms with particularly flexible wages. The degree of rent sharing and the labor share are also unaffected. We reject that disinvestment could have offset wage effects through the canonical hold-up channel, as shared governance, if anything, increases capital formation.
\end{abstract}

Simon Jäger

Department of Economics

MIT

50 Memorial Drive

Cambridge, MA 02142

and NBER

sjaeger@mit.edu

Benjamin Schoefer

Department of Economics

University of California at Berkeley

530 Evans Hall \#3880

Berkeley, CA 94720-3880

schoefer@berkeley.edu
Jörg Heining

Institute for Employment Research (IAB)

Joerg.Heining@iab.de 


\title{
Labor in the Boardroom*
}

\section{Simon Jäger \\ MIT and NBER}

\author{
Benjamin Schoefer \\ UC Berkeley
}

August 25, 2020

\section{Jörg Heining \\ $\mathrm{IAB}$}

\begin{abstract}
We estimate the wage effects of shared governance, or codetermination, in the form of a mandate of one third of corporate board seats going to worker representatives. We study a reform in Germany that abruptly abolished this mandate for stock corporations incorporated after August 1994, while it locked the mandate for the slightly older cohorts. Our research design compares firm cohorts incorporated before the reform and after; in a robustness check we additionally draw on the analogous difference in unaffected firm types (LLCs). We find no effects of board-level codetermination on wages and the wage structure, even in firms with particularly flexible wages. The degree of rent sharing and the labor share are also unaffected. We reject that disinvestment could have offset wage effects through the canonical hold-up channel, as shared governance, if anything, increases capital formation.
\end{abstract}

\footnotetext{
*sjaeger@mit.edu, schoefer@berkeley.edu, joerg.heining@iab.de. We thank the editor Lawrence Katz, and four anonymous reviewers. We thank Daron Acemoglu, John Addison, Josh Angrist, David Autor, David Card, Jonathan Cohn, Robert Gibbons, Lawrence Katz, Patrick Kline, Bentley MacLeod, Jim Poterba, Fabiano Schivardi, Antoinette Schoar, Andrei Shleifer, Sebastian Siegloch, David Sraer, Jean Tirole, Margarita Tsoutsoura, and John Van Reenen for useful discussions, as well as audiences at the AEA/LERA Meetings, CEPR/LSE Annual Labour Symposium, Columbia University, Columbia Micro Macro Labor Conference, CRC Berlin Workshop on the Future of Labor, CREST, CSEF Conference on Finance, Labor, and Inequality, EIEF, INSEAD, IZA, LSE, MIT Organizational Econ Lunch, NBER Corporate Finance Meeting, NBER Summer Institute Labor Studies, SOLE-EALE Meeting, Stanford Labor Seminar, Stanford SIEPR Workshop, Stockholm University, UC Berkeley, UCLA, UC Santa Cruz , UMass Amherst, UBC, U Mannheim, and U Montreal. For sharing their legal expertise, we thank Andreas Engert, Thomas Hoffmann, Marcus Lutter, Sebastian Sick, and Holger Spamann. Karl Aspelund, Nikhil Basavappa, Jonathan Cohen, Dominik Jurek, René Livas, Nelson Mesker, Enrique Perez, Martina Uccioli, and Dalton Zhang provided outstanding research assistance. We thank the MIT Sloan Good Companies, Good Jobs Initiative, the UC Berkeley Institute for Research on Labor and Employment, and the Washington Center for Equitable Growth for financial support. By focusing on wage outcomes in the administrative IAB data, this paper differs from a previous version that studied a broader set of financial outcomes in a larger and longer, multi-source Bureau van Dijk sample of firms rather than the IAB sample of firms (see Footnote 31.
} 


\section{Introduction}

A fundamental question of industrial relations concerns how the institutional form of organization of labor affects wage setting. With shared governance, or codetermination, workers participate in the decision-making of their employer, for example through representation on company boards. By contrast, in more adversarial labor relations systems such as in the United States, workers are largely barred from participation in corporate decision-making. Against the backdrop of rising wage inequality and decline in the labor share, several observers and policy-makers have called for an introduction or expansion of worker board representation as a way to boost worker bargaining power. 1 Whether minority board representation actually boosts worker bargaining power remains an open question. Even if it does, it may lead to agency problems, stifle investment, and thus ultimately lower wages (Jensen and Meckling, 1979). An ideal experiment to study the consequences of shared governance for wages would randomly assign the institution to some firms but prohibit it in others.

We provide quasi-experimental evidence on the effects of this form of shared governance by studying a 1994 reform in Germany that sharply abolished worker-elected directors in certain firms, and permanently preserved the mandate in others. Before the law change, all stock corporations (Aktiengesellschaften and Kommanditgesellschaften auf Aktien) had to apportion at least one third of their supervisory board seats to worker representatives. These worker board representatives are primarily non-managerial workers, proposed and directly elected by the non-managerial workforce. In two-tier board settings such as Germany's, the supervisory board appoints, monitors, dismisses, and sets the compensation for the executive board. It is also directly involved in important decisions, such as large investments or outsourcing. Anecdotally, many decisions in the supervisory board are taken unanimously, with consensus between shareholder and worker representatives (Gold, 2011; Steger, 2011). In the German industrial relations system, board representation coexists with two other institutions of worker representation. First, unions represent workers in collective bargaining negotiations, determining wage floors and hours, usually at the sector-region level. Second, works councils provide shop-floor representation and a

\footnotetext{
${ }^{1}$ Several legislative proposals in the United States Senate would mandate German-style board codetermination. For example, the Reward Work Act and the Accountable Capitalism Act would mandate 1/3 or 40\%, respectively, of directors of larger corporations to be elected by the workforce. In the United Kingdom, the government-commissioned Bullock Report called for worker representation on corporate boards (Report of the Committee of Inquiry on Industrial Democracy, 1977). More recently, the Labour Party proposed to mandate one-third codetermination in firms with more than 250 employees (Reuters, 09/23/2018). In an MIT Report on the "Work of the Future", Autor, Mindell, and Reynolds (2019) identify "restoring the role of workers as stakeholders, alongside owners and stockholders, in corporate decision-making" as critical to shaping the future of work. In his analysis of capital and ideology, Piketty (2020) argues for an expansion of codetermination rights.
} 
separate form of codetermination, e.g., regarding working conditions or layoff decisions. In many cases, board representatives also serve on works councils. Our paper includes a test for interactions of board representation with these two institutions.

The 1994 reform abruptly abolished worker-elected directors in new stock corporations (unless firm size crossed a high threshold of 500 employees). Importantly, the cohort-based reform locked in shared governance in the incumbent firm cohorts incorporated before the reform. The sharp law change permits us to identify the effect of shared governance by comparing stock corporations incorporated just before and after the August 1994 cutoff. We implement this design by combining firm-, establishment-, and worker-level data: (i) administrative matched employee-establishment data covering the universe of social security records merged with (ii) financial and production data for public and private firms based on Bureau van Dijk (BvD) data, (iii) a comprehensive data set of incorporations and exits, (iv) data on board composition for listed firms and (v) an establishment survey.

Our main specifications compare stock corporations incorporated in a two-year window around the reform. To assess the validity of the design, we (i) rule out manipulation of incorporation dates, (ii) rule out composition shifts at entry, (iii) argue that the grandfathering is binding (and note the Federal Constitutional Court has upheld the grandfathering ruling against shareholder law suits), (iv) rule out selective attrition in the form of firm exit, (v) estimate a series of robustness specifications varying the bandwidth between six months and five years, (vi) estimate the effects of placebo reforms. (vii) In additional specifications, we net out a broad class of cohort or age effects with a second difference among peer cohorts among unaffected corporation types (Gesellschaften mit beschränkter Haftung $(\mathrm{GmbH})$, which we will refer to as limited liability companies (LLCs)).2]

Our main finding is that firms that are assigned shared governance do not pay measurably higher wages than their peers without the mandate. We estimate small positive effects on composition-adjusted wage policies at the firm (Abowd, Kramarz, and Margolis, 1999), with point estimates between $0.4 \%$ and $2.3 \%$, and confidence intervals ruling out pay premia effects above $4 \%$ in simple difference specifications. We find similar point estimates but wider confidence intervals in RD specifications. We do not find effects on the wage structure inside the firm and measures of within-firm pay inequality. We also find no evidence for increases in the labor share: if anything, we find (insignificant) decreases of the labor share by about 0.03 (SE 0.03 , control mean: 0.73 ).

We provide three additional analyses to understand the absence of wage effects. First, we reject the possibility that wages did not increase on net because the bargaining power increase was offset by a tantamount decrease in the size of the firm's pie to be shared, by,

${ }^{2}$ German GmbHs are broadly comparable to private limited companies in the United Kingdom or LLCs in the United States. They differ from US LLCs in that they are formally corporations and in that their shares cannot be traded on a stock exchange. 
much like a distortionary profit tax, depressing capital formation following the influential hold-up view (Jensen and Meckling, 1979; Grout, 1984). In the data, we find that firms with shared governance produce, if anything, higher output, with an extra value added per worker (labor productivity) of 2 to $8 \%$. Specifically rejecting the hold-up mechanism, shared governance leads to larger fixed capital stocks and higher capital-labor ratios 3 Hence, the estimates reject the disinvestment predicted by the hold-up and agency cost views. We also find no evidence for reductions in revenue or employment.

Second, we directly estimate and compare rent-sharing elasticities in firms with and without this form of shared governance. We document similar elasticities of wages to firm-level value added per worker, of about 0.07 in our sample. This finding indicates that worker representation does not appear to raise worker bargaining power over wages.

Third, we conduct a series of institutional and theory-driven heterogeneity analyses, sorting firms into industries. First, we investigate the possibility that shop-floor works councils, which exist in many German firms, may duplicate (or amplify) some functions of board-level representation in our research design. We do not find substantial heterogeneity along this dimension either; if anything, we find larger wage effects in industries where works councils are more prevalent. Our research design does speak to the potential independent wage effects of plant-level works councils. Second, even in high-rent firms (high labor productivity, high firm AKM effects, or low turnover), shared governance does not lead to wage increases. Third, even for industries with low coverage of collective bargaining agreements and large revealed wage dispersion, wage effects remain absent. The lack of heterogeneity in wage effects also suggests that our findings may extend beyond institutional settings similar to Germany.

A priori, one-third board representation could have affected wages through various concrete channels in addition to raising worker bargaining power (Jensen and Meckling, 1979: Grout, 1984). For example, worker representatives could have pushed for the selection of labor-friendly managers (Bertrand and Schoar, 2003) or changed pay equity norms (Western and Rosenfeld, 2011). They could have affected firms' decision to accede to or opt out of collective bargaining agreements (CBA), decisions in which supervisory boards can be involved (see Schnabel and Wagner, 1996, for a survey on CBA coverage and worker representation). The full information rights of the board members could have improved workers' and works councils' wage negotiation outcomes (Addison, Teixeira, and Zwick, 2010), for example as even worker board representatives who also serve on the

${ }^{3}$ Our evidence against hold-up effects is consistent with (Machin and Wadhwani, 1991: Addison et al., 2007: Card, Devicienti, and Maida, 2014), even though some studies document negative investment effects of unionization (e.g., Connolly, Hirsch, and Hirschey, 1986; Hirsch, 2004). In the context of codetermination via works councils, Addison et al. (2007) finds no association with lower investment. Rapp et al. (2019) find positive effects of board representation based on a propensity score matching strategy among listed firms. 
works council report an information advantage by virtue of their board membership (see interviews with German representatives in Gold, Kluge, and Conchon, 2010) 4 By facilitating cooperation, by institutionalizing communication, or through repeated interactions between labor and capital, shared governance could have helped overcome hold-up and raise productivity and, in turn, wages through rent sharing (Malcomson, 1983: Crawford, 1988; Freeman and Medoff, 1985; Freeman and Lazear. 1995). In practice, most supervisory board decisions are unanimous (Gold, 2011; Steger, 2011), leaving room for real authority even absent formal majority rights (Aghion and Tirole, 1997). We discuss potential institutional explanations for the empirical absence of wage effects in the conclusion.

Consistent with the absence of wage increases and of negative effects on firm performance, we find no evidence for higher or lower profitability, in contrast to some evidence for negative profit effects of firm-level unionization in adversarial settings (see, e.g., Lee and Mas, 2012). We caveat that our data do not contain dividend payouts, as most of the stock corporations are not publicly traded. Similarly, firm owners do not appear to strategically avoid the institution by delaying incorporating or shifting corporate form, all consistent with owners reporting that one-third representation does not substantially affect incorporation choices (Albach et al., 1988).

Our quasi-experimental research design complements studies comparing firms with and without codetermination using size cutoffs on non-wage outcomes. Gorton and Schmid (2004), Kim, Maug, and Schneider (2018) and Redeker (2019) study large, publicly traded corporations at the 2,000 employee threshold, which delineates one-third and quasi-parity employee representation (in the latter group, shareholder representatives still break ties). Compared to these studies, our variation has no worker-elected directors in the control group. Our cohort-based variation also circumvents endogenous contemporaneous employment as an assignment variable, which is transitory exactly around the threshold. Instead, our variation draws on persistent regimes, sharply assigned by incorporation date. By contrast, Svejnar (1981) analyzes the effect of the introduction of parity codetermination in 1951 in the iron, steel and mining sector compared to unaffected industries, finding a $6 \%$ wage effect on sector-level average wages on the basis of industry wage tabulations; FitzRoy and Kraft (1993) study the effect of the 1976 introduction of quasiparity representation and find small effects on labor costs per employee. Our study of board-level representation (see Scholz and Vitols, 2019, for a review) complements studies of plant-level works councils (e.g., Addison, Schnabel, and Wagner, 2001; Addison, 2009).

In Section 2, we describe the institutional context and the reform. Section 3 presents our data sets. Section 4 assesses the validity of the design by measuring avoidance, exit, and

${ }^{4}$ This mechanism may be especially relevant when CBA opening clauses allow for local wage negotiation (Brändle, Heinbach, and Maier. 2011: Dustmann et al., 2014), or among firms not part of a CBA so that works councils are directly involved in wage setting $(\$ 87$, Betriebsverfassungsgesetz). 
entry effects. Our main findings on wage setting are reported in Section 5. Heterogeneity analyses guided by a bargaining model are presented in Section 6. Section 7 concludes.

\section{Institutional Context and the 1994 Reform}

We describe shared corporate governance in Germany, and the 1994 abolition of board-level representation in most new stock corporations. We also review wage setting institutions.

\subsection{Shared Corporate Governance in Germany}

Corporate Governance in Germany Like many other European countries, Germany has a two-tier board system, an executive and a supervisory board, illustrated in Figure 1. The executive board is the managing body and responsible for day-to-day business. The supervisory board - composed of representatives for shareholders and, in many cases, workers - is responsible for the selection, monitoring, auditing, compensation structuring, and dismissal of the executive board ( $\$ \S 84,87$ and $111 A k t G$ ). The German Corporate Governance Code advises that the supervisory board be involved in all decisions of fundamental importance to the company, e.g., strategic planning and larger financial decisions. For instance, corporate charters frequently prescribe thresholds above which investments need to be directly approved by the supervisory board. The supervisory board is also often involved in large decisions that are directly relevant to wage setting, such as whether the company joins an employer association or not (and thereby accedes to collective bargaining agreements). Anecdotally, votes on the supervisory board are often unanimous even with worker representatives (Gold, 2011; Steger, 2011).

Shared Governance: Works Councils Two institutions allow for worker representation in employers' decision-making: shop-floor codetermination through works councils and board-level codetermination on the supervisory board. Works councils (for recent studies, see Addison, Schnabel, and Wagner, 2001; Addison, 2009) are a shop-floor representation institution and have extensive consultation, information, and codetermination rights in areas such as work hours, occupational safety, and organizational or staffing changes, and can directly negotiate with the employer, including over salaries. This institution goes back to the early 1900s. The role of works councils is regulated in the Establishments Constitution Act (BetrVG). In establishments with more than five employees, workers have the right to organize in a works council; multi-establishment firms that have plantlevel works councils additionally coordinate via a firm-level variant. In Section 6.5, we will investigate whether codetermination through board representation interacts with the 
prevalence of works councils; yet, our design cannot provide estimates of the independent effect of works councils on wages.

Shared Governance: Board Representation The variation we study concerns mandates for firm-level codetermination on the supervisory board, an institution introduced in the early years of the Federal Republic of Germany (see Scholz and Vitols, 2019, for another review) $5^{5}$ Importantly for our study, the codetermination mandates differ by legal form and incorporation date (and also employee count). The board seats allocated to worker representatives range from zero to full parity.

In 1951, the first landmark act mandated supervisory board parity in the mining, coal, and steel sectors for firms with more than 1,000 employees.

In 1952, the second landmark act introduced the one-third mandate for corporations. This mandate exempted state-owned firms and firms with fewer than 500 (today: 501) employees unless they are stock corporations not $100 \%$ owned by one family.

In the 1960s, the union movement began pushing for further expansion of worker representation, and the social-liberal coalition passed the 1976 codetermination law (MitbestG), which mandated quasi-parity in non-mining/steel sectors for firms with more than 2,000 employees: workers elect $50 \%$ of the seats (quasi-parity), but the chairperson, who is generally a shareholder representative, can break ties.

Worker board representatives are elected by the firm's non-managerial workforce in general, secret, equal and usually direct elections, organized through the works council. 6 Worker board representatives typically also serve on the works council. Once elected, the worker representatives are co-equal directors with the shareholder representatives. All (or, for larger firms, the majority) of the worker representatives on the supervisory board must be employees of the firm. For larger firms with larger boards, the union can nominate additional external candidates ( $\S 7$ Mitbest $G, \S 4$ DrittelbG). Though not required by law, a large share of worker-elected directors are union members (Addison, 2009). Unions and associated organizations also offer training programs for worker representatives on supervisory boards.

As a result of these laws, in firms with 501 to 2,000 employees, workers elect one third of the seats no matter the legal form. We will find that fewer than $10 \%$ of firms cross the 500 threshold in our analysis sample. All other firms cannot have worker board representatives below this 500 threshold.

${ }^{5}$ The historical context was favorable for shared governance because, while industry leaders had collaborated with the National Socialist regime, the workers' movement was less tainted. Shared governance was also viewed as an acceptable compromise to many firm owners in light of nationalization episodes in the United Kingdom (McGaughey, 2017).

${ }^{6}$ In firms with more than 2,000 employees, the managerial workforce also participates in the elections and sends at least one representative ( $\S 15$ Mitbest $G)$. 
Starting 1952, there was a single exception to the exemption from board representation even for the vast majority of firms below 501 employees: stock corporations were mandated to have one-third representation no matter their size, even though, we show, the vast majority of stock corporations are below this threshold. We exploit the sudden abolition of this mandate for newly incorporated stock corporations described below. Hence, the variation we study is between mandates for zero or one-third worker-elected directors among stock corporations. Figure 1 illustrates corporate governance with one-third (Panel (a)) or no worker participation (Panel (b)).

\subsection{Abolition of Shared Governance in New Stock Corporations}

Since 1952, stock corporations had been required to have at least one-third worker representation on the supervisory board regardless of size. A 1994 reform of the Stock Corporation Act (Aktiengesetz) and the Works Constitution Act (Betriebsverfassungsgesetz) abruptly abolished this requirement for newly incorporated stock corporations while preserving it in existing ones.7 The law was a result of a last-minute political compromise and did not affect LLCs or other features of shared governance. The goal pursued by abolishing codetermination in stock corporations was to harmonize the rules for stock corporations with those of LLCs. Figure 2 Panel (a) illustrates the reform-induced changes in the mandate as a function of a firm's incorporation date. These differences in the mandate by incorporation date continue to the present.

Abolition in Stock Corporations Founded after August 10th, 1994 The reform abolished the one-third mandate only for new stock corporations: those incorporated on or after August 10, 1994. As a consequence of the reform, new stock corporations smaller than 501 employees cannot have any worker-elected board members, as the corporate law leaves no room for choice (see, e.g., Raiser, Veil, and Jacobs, 2015, § 1 Rn. 26, § 23 (5), and § 96 AktG) ${ }_{8}^{8}$ Figure 1 Panel (b) illustrates corporate governance in these corporations without the mandate. Upon having 501 employees, both cohorts face the same one-third mandate. 9

\footnotetext{
${ }^{7}$ See BGBl. I 1994 p. 1961. Today, the grandfathering rule with the 1994 cutoff is part of the OneThird Participation Act (Drittelbeteiligungsgesetz), which in 2004 subsumed the relevant parts of the Works Constitution Act.

${ }^{8}$ In principle, LLCs could add additional worker representatives exceeding the fractions mandated by law, although anecdotal evidence suggests that this is not common. In any case, rules for LLCs were not changed by the 1994 reform.

${ }^{9}$ For the vast majority of firms, the 500 employment cutoff is not binding. Among stock corporations incorporated after the reform, fewer than $7 \%$ of firms reach the 500 employee threshold using IAB employment data (and fewer than $1 \%$ among the LLCs).
} 


\section{Political Compromise: Grandfathering of Codetermination in Existing Firm Cohorts}

Importantly, the law locked in the one-third worker representation mandate in already founded stock corporations. This cohort-specific grandfathering rule arose as a lastminute political compromise in late May 1994, between the conservative-liberal governing coalition, between Christian Democrats (CDU/CSU) and Free Democrats (FDP), and the center-left opposition Social Democrats (SPD), who held a majority in the upper chamber (Bundesrat). The conservative-liberal government had proposed to abolish shared governance in all stock corporations (up to 500 employees), including existing ones, to harmonize rules between stock corporations and LLCs and to deregulate and simplify the corporate and codetermination law. By contrast, the opposition had been in favor of maintaining shared governance for all stock corporations - new and old. A key rationale for the cohortbased compromise was that existing companies were believed to have already learned to operate under the mandate. Upon reaching the political compromise, the law was then promptly passed in both chambers in the subsequent weeks, and mandated a cutoff date of August 10, 1994, the day after the law's promulgation. ${ }^{10}$

Rigidity of the Cohort-Based Lock-In Notably, grandfathered stock corporations incorporated just before August 10, 1994 cannot simply escape the shared governance mandate by re-incorporating. Specifically, a change of legal form and temporally connected reincorporation of an old stock corporation as an ostensibly new stock corporation does not invalidate the mandate for board representation of workers.11 1994 grandfathering rule has been challenged in legal cases brought by shareholders of older corporations on the grounds that the arbitrary nature of the cutoff date violates the constitutional principle of equality. However, the courts have upheld the clause, including the Federal Constitutional Court as recently as 2014 (BVerfG, 09.01.2014, Az. 1 BvR 2344/11).

Secondary and Non-Grandfathered Elements of the Reform In addition to shared governance, the 1994 law changed several other rules in the Stock Corporation Act (e.g., use of

${ }^{10}$ The initially proposed bill and compromise committee recommendation are reported in Drucksache 12/6721 and 12/7848 (Deutscher Bundestag, 1994), the minutes of plenary proceedings in Plenarprotokoll 12/233 and 12/237 (Stenographischer Bericht, Deutscher Bundestag, 1994).

${ }^{11}$ See, for example, Raiser, Veil, and Jacobs (2015) § 1 Rn. 5. Re-incorporations as corporations according to European law (SE) also entail a grandfathering rule such that employee representation is preserved, even if the corporation adopts a unitary board structure (§ 21 (6) SEBG). In theory, re-incorporation as LLCs could undo the grandfathering rule (although LLCs can also opt to keep workers on the board). During our sample period, re-incorporation as an LLC requires at least $75 \%$ of shareholder votes (§ 240 (1) UmwG), although additional requirements apply in certain cases $(\S 242$ UmwG). We did not identify cases where stock corporations switched corporate form to an LLC to evade the grandfathering rule. Likewise, the legal practitioners we consulted deemed this scenario unlikely due to, among other reasons, switching costs. On aggregate, such evasion behavior would show up as increased exits, which we do not detect in our survival analysis in Figure 3 Panel (d) described in Section 4. 
profits, general shareholder meetings), all of which applied regardless of the incorporation date and hence had no grandfathering - such that they would affect both cohort groups and hence be netted out in our difference between stock old and young stock corporations. Crucially, only the shared governance setup was grandfathered in for existing corporations. Moreover, the additional features of the 1994 reform were considered secondary to the abolition of shared governance by commentators.12 In principle, such non-grandfathered features could still have effects in our research design if they affected the quantity or composition of post-1994 entrants. In Section 4, we will directly assess these potential confounders, and empirically find that the reform had no detectable effects on these margins. From that perspective, the broader motivation surrounding the reform to spur entrepreneurship among stock corporations is not borne out in the data (and in any case, our research design would net out any common effects on both older and younger stock corporations).

\subsection{Wage Setting in Germany}

The German labor market features considerable scope for firm-level wage setting, such that in principle shared governance could affect the wage setting of the treated firms compared to control firms. Sectoral bargaining, usually at the sector-state level, where unions negotiate wage floors, hours and working conditions with employer associations, leaves substantial scope for firm-specific deviations. Most importantly, covered employers can always deviate upwards (Günstigkeitsprinzip, § 4 (3) TVG). Moreover, collective bargaining coverage has decreased substantially while the prevalence of opening clauses, allowing individual firms and workers to negotiate wages lower than those in the CBA, has risen (Brändle, Heinbach, and Maier, 2011; Dustmann et al., 2014). Hence, worker representatives on the works council (who are typically also board directors in case a firm is subject to board codetermination) are directly involved in wage negotiations among firms that are not part of a collective bargaining agreement (\$87, Betriebsverfassungsgesetz) and in firms taking advantage of a CBA opening clause. Consistent with considerable scope for firm-level wage setting, there is large between-firm dispersion in wage premia even within industries (Card, Heining, and Kline, 2013). Similarly, idiosyncratic shocks to localities or firms, e.g., corporate tax changes or labor supply shocks, affect wages (Fuest, Peichl, and Siegloch, 2018; Jäger and Heining, 2019). In the introduction, we have reviewed concrete channels through which board representation can affect firm-level wages.

In our rent sharing analysis, we estimate the effect of firm-specific productivity on firm-level wages in the German context controlling for industry effects. We further analyze

\footnotetext{
${ }^{12}$ For example, the Frankfurter Allgemeine Zeitung, a newspaper of record in Germany, considered the changes irrelevant except for the codetermination reform ("Nicht nur weiße Salbe", Frankfurter Allgemeine Zeitung, May 27, 1994, p. 13).
} 
potential interdepencies between board-level codetermination and the two other forms of worker involvement in wage setting, through collective bargaining agreements and works councils.

\section{Data and Sample Construction}

Matched Firm-Establishment-Worker Data: Orbis-ADIAB Our main dataset is administrative employer-employee data from IAB merged with Bureau van Dijk Orbis (BvD) firm-level data (Antoni et al., 2018) 13

The matched employer-employee data are based on social security records and cover the universe of jobs subject to social security contributions from 1975 to 2014 . In the matched employer-employee data, we keep full-time workers aged 20-60. The data consist of day-specific spells. We drop spells with less than 1 EUR per day. In each calendar year, we keep one spell per worker, specifically the one with the highest total annual earnings. Our IAB employment measure refers to these worker-firm matches. Our wage concept is the daily wage (total earnings divided by number of days of the spell) of these full-time workers, which we deflate using the 2015 CPI.

The BvD data are balance sheets and income statements based on official company registers, company reports, and information from credit rating agencies. The Orbis-ADIAB version covers 2006 through 2014. The BvD data contains the information about legal form and incorporation of the firm. We deflate all BvD nominal variables with the 2015 CPI.

The matching of IAB and BvD data was conducted via establishment-level record linkage from 2006 to 2014. The match rate for stock corporations is the highest among all legal forms at 70.34\% (Antoni et al., 2018).

Analysis Sample Our sample consists of stock corporations (and, as an additional control group for a difference-in-differences analysis, LLCs) incorporated from 1989 through 1999 - five years around the August 1994 reform cutoff. Our main specification will apply a bandwidth of two years around the reform, and we will explore robustness to the full set of bandwidths within the five-year window, as well as donut hole specifications. For our wage analyses, we draw on data starting the calendar year after a firm's incorporation. We detail the two assignment variables of our design, legal form and incorporation date, as well as further sample restrictions below.

${ }^{13}$ By focusing on wage outcomes in the administrative IAB data, this paper differs from a previous version that studied a broader set of financial outcomes in a larger and longer, multi-source Bureau van Dijk sample of firms rather than the IAB sample of firms. Footnote 31 summarizes the robustness of the main results. 
Incorporation Date We use the exact date of incorporation merged on with an additional data delivery from $\mathrm{BvD}$. We also draw on additional $\mathrm{BvD}$ waves to assign each firm the earliest date reported across all BvD waves. ${ }^{14}$

The standard $\mathrm{BvD}$ incorporation date is the establishment date of its corporate charter (Feststellung der Satzung). The date relevant to the 1994 reform cutoff, however, is the entry into the Commercial Register (Handelsregister), which in the 1990s occurred sometimes up to a few months afterward. We merge on this information from the BvD Dafne data set; for the unmatched firms, we keep the original incorporation date 15 In the 1990s, the register entry was delayed by around two to four months after the charter date, so we replace it if the gap is at most one year, to ensure sharpness of our local design at the policy threshold. ${ }^{16}$ In our empirical design, we address any remaining mismeasurement concerns with robustness checks in the form of donut hole specifications and varying the bandwidths around the reform date.

Legal Form We keep stock corporations (Aktiengesellschaften and Kommanditgesellschaften auf Aktien) and LLCs (Gesellschaft mit beschränkter Haftung), using the BvD legal form variable 17

Further Sample Restrictions We implement additional sample restrictions. First, we exclude firms in industries exempt from codetermination. ${ }^{18}$ We additionally drop a handful of specific firms based on a firm-by-firm review of stock corporations and a string-search

\footnotetext{
${ }^{14}$ We draw on the Amadeus/Orbis June 2020 version of the Wharton Research Data Services (which is a panel data set going back multiple years for each firm). Since the IAB version of the BvD data covers 2006-2014, we additionally obtain historical BvD waves by drawing on the Orbis Historical product and from the LMU-ifo Economics \& Business Data Center (EBDC).

${ }^{15}$ Even in the case of divergence in the merged sample, the register date is always later than the charter $\mathrm{BvD}$ date, suggesting that larger deviations are due to re-incorporations. Importantly, as described in Section 2.2. old stock corporations cannot escape the mandate by re-incorporating as a new stock corporation after 1994, so such cases leave out assignment of firms into treatment and control groups intact. Hence, for any firms for which we cannot merge on the register date, the BvD date remains the relevant binding date and we correctly classify these firms.

${ }^{16}$ We thank Thomas Hoffmann for an email correspondence regarding the typical delay between charter and Commercial Register entry among Vor-AGs and Vor-GmbHs in the 1990s.

${ }^{17}$ The Orbis-IAB data set reports only one legal form per firm. For firms for which we have legal form information pre-2006 (the year the ORBIS-IAB data starts) in our external historical BvD data described in Footnote 14 , we use the earliest reported legal form.

${ }^{18}$ We use the BvD industry code and assign the firm its modal primary industry code in the case of panel variation, and replace missing primary industry information with secondary industry codes. We drop firms without any industry information. Legally, $\S 1$ (2) DrittelbG exempts enterprises that predominantly pursue political, coalitional (labor or employer representation), religious, charitable, educational, scientific or artistic goals as well as media organizations. We drop firms with the following NACE codes: utilities (35-39), rail transport (490-492), media $(5813,60)$, education and scientific activities $(72,85$, excluding driving and flying schools (8553)), and public administration $(84,99)$, charities $(87,88)$, membership organizations (94) and household activities $(97,98)$.
} 
algorithm of both stock corporations and LLCs.19 Second, we drop firms with headquarters in East Germany to drop entrants following of the reunification in 1990 to avoid potentially unrepresentative selection due to, e.g., privatizations of formerly state-owned firms. Third, we drop firm-years with fewer than 10 full-time employees in the IAB data.

Intent-To-Treat Interpretation Our reduced form design will yield intent-to-treat estimates as by its nature it must not condition on time-varying endogenous firm characteristics that affect codetermination rules. First, we do not condition on employment, in particular not restricting the sample to firms with fewer than 501 employees. This share is low even among stock corporations (incorporated after the reform, i.e. a control mean), fewer than $7 \%$ of firms reach the 500 (IAB) employee threshold (and fewer than $1 \%$ among the LLCs). This small share of firms that cross the threshold are simply always-takers (in the sense of having board-level codetermination regardless of the incoporation date). We do not find evidence for changes in the probability of crossing the 501 employee threshold. Second, and relatedly, we do not condition on membership in a corporate group as individual firms may be part of a corporate group that is subject to codetermination. Only $10.7 \%$ of our stock corporation control group are part of such a corporate group and we find no evidence that older stock corporations are more likely to be part of a corporate group sufficiently large (2001 and larger) to automatically trigger codetermination for all group members. Finally, we do not condition on whether firms are fully owned by one family. Legally, fully family-owned stock corporations smaller than 500 employees are exempt from codetermination. We do not apply this test because in a previous version of the paper we estimated (constructing family ownership on the basis of owners' last names in the BvD ownership data) that only $10 \%$ of our control stock corporations fulfill the strict criteria: in contrast to the usual definitions of family firms (at 50\% of direct ownership by a family), the codetermination law requires $100 \%$ of direct and indirect family ownership. Since ownership structure and specifically concentration of large shareholders is a potentially time-varying outcome itself, we do not apply this test. Overall, our results thus have an intent-to-treat, reduced-form interpretation with a group of never-takers (fully family-owned firms) as well as always-takers (firms that grow above 500 employees or are part of a large corporate group with codetermination).

\footnotetext{
${ }^{19}$ We generate this drop list in an external BvD data set described in Footnote 14 and then merge it on the ORBIS-ADIAB data set in an anonymized process. Namely, we drop a small number of firms we identify as associated with Deutsche Telekom, Deutsche Bahn, and Deutsche Post, which were privatized in the mid-1990s, public savings and cooperative banks, holdings, and strings associated with nonprofits ("e.V." and "gemeinn"), as well as subsidiaries of older firms (Lufthansa, Merck, Thyssen, Fielman, Daimler), media companies (using string search), and utilities-related string searches. In a previous version of the paper, we further dropped state-owned firms based on BvD ownership data outside of the ORBIS-IAB data set. Since this test only dropped one stock corporation (after having restricted the sample as described above) and since the ownership information is imperfect, we do not impose this additional restriction.
} 
Winsorization We winsorize all continuous variables at the $1 \%$ level separately by calendar year. Before winsorizing, we set BvD variables to missing if spuriously negative (e.g., fixed assets and value added, but not, e.g., profits).

Entrants \& Exits: Mannheim Enterprise Panel (MUP) We use firm panel data from the Mannheim Enterprise Panel (provided by ZEW, Mannheim, see Bersch et al., 2014) to comprehensively study incorporations and exits from 1991 onward (provided by Creditreform e.V., Germany's largest credit rating agency, based on official registers). We apply the same industry tests as before. Since core outcome variables are not reported in the early years in which we do not have Bureau van Dijk coverage, we do not use the MUP data to study outcomes. Data access is only permitted in the research data center, and we cannot merge this data with our ORBIS-ADIAB data set. These data also do not contain financial or labor market information for the period not covered by our main data sets.

Worker Supervisory Board Representation: Hoppenstedt Aktienführer While our sample of BvD firms does come with some board membership information), it does not differentiate between worker and shareholder representatives. To provide one intervention check that the reform shifts board composition, we draw on the Hoppenstedt Aktienführer covering all listed German firms and covering 1979 to $2015 \sqrt{20}$

IAB Establishment Panel To assess effect heterogeneity by the prevalence of works council as well as the extent to which collective bargaining agreements bind in an industry, we draw on the IAB Establishment Panel (Fischer et al., 2008). The IAB Establishment Panel is an annual survey of 16,000 establishments from all sectors and size categories. We use the waves starting 2008 for industry classifications consistent with the BvD panel, weighting establishments by employment. IAB data protection rules prohibit us from merging this survey with our ORBIS-ADIAB data set.

Summary Statistics Since all variables are potential outcome variables (as treatment is assigned at the date of incorporation), we report control means in each regression column (separately for stock corporations and LLCs incorporated after the reform).

${ }^{20}$ The historical Hoppenstedt Aktienführer data have been digitized through a project by the German Research Foundation (DFG) and were retrieved from https://digi.bib.uni-mannheim.de/aktienfuehrer/ 


\section{No Effects on Avoidance and Firm Exit}

We test for threats to identification, and answer the substantive questions whether firm owners evade shared governance by retiming incorporations or switching corporate form, and whether the institution affects firm exits.

Strategic Delay of Incorporation: McCrary Test Firms might delay incorporation date around the reform cutoff date. Our first check is a visual inspection of the incorporation frequency of stock corporations around the reform cutoff (Figure 3, Panel (a)). This analysis uses our Orbis-ADIAB analysis sample. The figure reveals no evidence of a spike in incorporations after August 10, 1994, nor of a missing mass of incorporations leading up to the reform. In the same figure, we formally implement a McCrary (2008) test of continuity of the density against the alternative of a jump in the density function at the reform cutoff date, for which we find no evidence $\left(0.439\right.$, SE 0.628) ${ }^{21}$

Several institutional features render these two types of substitution unlikely a priori, as discussed in Section 2. The grandfathering was an unexpected political compromise, with no clear advance indication that strategic delay of incorporation would relax the firm's mandate. In addition, the legislative process was finalized within weeks of reaching the compromise and mandated the day after the law's promulgation as a cutoff date.

Composition of New Firms by Legal Form Relatedly, more firms may substitute into the legal form of stock corporation after the reform rather than an LLC. Figure 3 Panel (b) plots the percentage of stock corporations against time of incorporation in a sample of both LLCs and stock corporations. The probability of incorporating as a stock corporation did not change discontinuously around the reform cutoff date.

In addition, we test less locally whether the reform affected substitution in terms of legal form in our sample window. To this end, we regress an indicator for incorporation as a stock corporation on a post-reform indicator, a time trend, and the interaction of the two. We find a small, secular trend towards incorporating as a stock corporation, but we do not detect a level shift or trend change between the pre- and post-reform period (see Figure 3p and Appendix Table A.1). This finding implies that the reform overall, which in part aimed to encourage entrepreneurship in stock corporations, did not appear to have spurred a higher quantity of entrants into this legal form. ${ }^{22}$

\footnotetext{
${ }^{21}$ Appendix Figure A.1 conducts this test in the Mannheim Enterprise Panel, which contains comprehensive data on entrants (rather than survivors in the Orbis-ADIAB data) from 1991 onward.

${ }^{22}$ This finding is also consistent with a survey sampling stock corporations founded between 1994 and 1996 (Schawilye, Gaugler, and Keese, 1999). The reported top reasons for incorporating as a stock corporation rather than an LLC are: (1) image and public relations concerns (high prestige of stock corporations), (2) raising capital, (3) corporate organization, (4) generational change and transfer of ownership.
} 
Selection Test: Industry Composition Our design cannot test for selection by studying observables of firms because these are outcome variables potentially affected by the reform. Instead, we study one perhaps less mutable outcome determined at entry and hence indicative of selection, namely industry composition. We consider a firm's industry (17 industry NACE Level-1 codes) as binary outcome variables. We study simple difference effects between stock corporations incorporated in a two-year window before and after the 1994 reform. We also study the double difference, comparing the difference in industry composition between stock corporations incorporated before and after the reform to that for LLCs (which were not affected by the reform and are a second control group), as well as a regression discontinuity approach; we formally describe these regression specifications below in Section 5. We report results based on the Orbis-ADIAB data for each industry in Figure 3 Panel (c), with detailed regression results in Appendix Table A.2. The reform did not statistically significantly affect the industry composition of firms; the coefficients are jointly insignificant in an F-test $(p=0.384, p=0.396$ and $p=0.828$, respectively, for the three approaches). This test also rules out spurious composition effects from, e.g., business cycles or trends around the reform cutoff. ${ }^{23}$

Attrition: Effects on Firm Survival To rule out selective attrition - and as an outcome variable in its own right - we estimate effects on firm exit. Here, we draw on the comprehensive information on all firm incorporations in Germany from 1991 onward (from the Mannheim Enterprise Panel, while our BvD data consist of survivors' panels from future years). Figure 3 Panel (d) plots the survival probability of stock corporations by incorporation date, grouped within a two-year window before the reform ("Old") and after ("Young"). Across groups, around 50\% of firms exist at age 20. Survival rates are very similar albeit slightly lower among the younger stock corporation cohorts, if anything, suggesting that shared governance raises firms' resilience. However, first, we find that these slight differences completely disappear after age five, as illustrated in Appendix Figure A.2 Panel (a). That is, conditional on firms surviving to year five, survival functions are identical. Second, even in the early years, the survival is not differentially lower or higher for old and young stock corporations when compared to the same cohort difference within LLCs, a placebo group, which was not exposed to the 1994 reform (which only changed

\footnotetext{
${ }^{23}$ We also study composition effects in the universe of entrants, using the Mannheim Enterprise Panel (MUP, see Appendix Figure A.1 Panel (b)). Here, we find no statistically significant effects for 15 of the 17 industries. The two exceptions are a small reduction in communications and a small increase in finance/insurance firms, and the $F$-test indicates significant effects $(p<0.01)$. These mild composition effects in the comprehensive MUP population may not show up in our Orbis-ADIAB analysis sample because of the additional sample restrictions we apply in the latter (at least ten employees, West German location, active in some year from 2006 onward, dropping industries not subject to codetermination). Alternatively, exits may have ironed out initial composition differences in our Orbis-ADIAB time, which starts in 2006.
} 
codetermination rules for stock corporation cohorts). We also plot these lines in Panel (d). As a complement, we report the corresponding difference-in-differences estimates on the exit probability (one minus survival probability) by firm age in Appendix Figure A.2Panel (b). The confidence interval confidently includes zero even 20 years out (similarly for cumulative probability of exiting by bankruptcy, the only subcategory of exit the MUP data separate out). In any case, our analysis will always separately present simple differences between cohorts of stock corporations as well as the difference-in-differences with LLCs, and our results will be robust to either specification. In sum, we do not find evidence for differential attrition from shared governance. This result is also of substantive interest, revealing that shared governance does not appear to affect firm survival.

Validation Test: Realized Shifts in Worker Representation A potential explanation for the absence of avoidance behavior could be that the reform had no bite and, in fact, did not shift the presence of workers on corporate boards. We now verify that the reform did shift worker representation by incorporation date. Figure 2 Panel (b) shows the empirical share of workers on the supervisory board by incorporation date and firm size. We draw on data from the Hoppenstedt Aktienführer, which lists supervisory board members and incorporation year for the subset of listed stock corporations. We restrict the sample to stock corporations founded between 1989 and 1999 for which board composition data is reported. ${ }^{24}$ The left (navy-colored) and right (red) bar pairs represent corporations incorporated during or before 1994, and, respectively, during or after 1995. For firms smaller than 500 employees (in dark shades, for which the reform changed the rules), there is a stark difference: workers hold $29 \%$ of the seats in stock corporations incorporated in or before 1994. In sharp contrast, workers comprise only around 3\% of the seats in stock corporations founded after 1994. The non-zero worker share is likely due to a small amount of measurement error as the employment concepts for codetermination and in the Hoppenstedt data might differ slightly. The lighter shades report analogous outcomes for very large firms, for whom the mandate did not change and for whom the data show no difference in worker representation - both around one third - confirming that the comparison is not driven by shifts in reporting or data quality after 1994.

Employer Attitudes Towards Board-Level Representation We close with a discussion of existing work on employers' and managers' views towards board-level codetermination. A body of work from the varieties of capitalism literature has argued that employers have embraced codetermination as a competitive advantage through its facilitation of coop-

\footnotetext{
${ }^{24}$ Specifically, we only consider firm-year observations with data on the role (chair person, worker representative, etc.) of individual supervisory board members is reported for at least one third of the supervisory board. We rely on data from the 1990s due to a structural break in reporting in 2000.
} 
eration (Hall and Soskice, 2001: Thelen, 1991). Historically, the original introduction of board-level representation in the Weimar Republic was heavily opposed by parts of the workers' movement and the parties of the far left (Winkler. 1998); later, the Social Democrats and the largest unions unsuccessfully opposed the introduction of one-third codetermination in post-war Germany, the institution we study, as they viewed the institution as too favorable to the capital side (McGaughey, 2017). Regarding the more recent past, a metastudy of survey evidence and media statements has documented considerable support for board-level codetermination among individual managers and firms along with more negative views from employer associations (Paster, 2012). ${ }^{25}$ In a survey of firms incorporated before the 1994 reform and thus directly related to our sample, Albach et al. (1988) find that codetermination in the supervisory board is generally not seen as an impediment to incorporation as a stock corporation. Rather, the surveyed firms generally accept shared governance, in particular because of the information and specific knowledge about the firm that worker representatives bring to the board room, and oppose the abolition of shared governance.

\section{Effects on Wages, Wage Policies, and Wage Structure}

We introduce our research design studying the wage effects of shared governance with a detailed analysis of raw wages. We then report results on wages adjusted for worker demographics, on firms' pay premia net of worker selection, and on the wage structure inside the firm.

\subsection{Raw Worker-Level Wages}

Cohort Graphs by Calendar Time Figure 4 Panel (a) nonparametrically plots raw workerlevel log wages separately for treated and control firm cohorts against calendar time. The figure first averages worker-level wages at the firm-year level, and then at the group-year level. The comparison is between stock corporations incorporated in a two-year window before the reform and hence with a shared governance mandate ("Old Stock Corporations," plotted in navy circles with a solid line) and those in a two-year window after ("Young," plotted in red hollow circles with a dashed line). For most of the years, the two lines lie on top of each other, indicating no discernible wage differences. Before 1999 a small positive difference is visible. Around 2009, the older stock corporations see a larger real wage

${ }_{25}$ Paster (2012) argues that employer associations may have an incentive to strategically overstate the concerns of their dissatisfied members. For the context of works councils, Müller and Stegmaier (2020) provide evidence that employer associations may resist expansions of codetermination even though employee participation may entail, on average, positive effects on productivity or profits. 
increase of about $5 \log$ points and thereafter continue to evolve in parallel. This simple plot of raw data is direct nonparametric evidence that shared governance does not appear to substantially raise wages.

The Orbis-ADIAB data set has the fullest coverage between 2006 and 2014, i.e. the years during which the linkage between the $\mathrm{BvD}$ firms and the IAB matched employeremployee data was performed year-by-year. The matched employee-establishment (IAB) component of the merged Orbis-ADIAB data set goes back earlier than the BvD Orbis outcomes, permitting us to study the firms already between their incorporation time and 2006, namely for those establishments subsequently present during the linkage period as described in Section 3. As a result, coverage declines for the earlier years with perhaps some positive selection of surviving establishments, which likely explains why the figure suggests stagnant real wages before 2006. In the figure and throughout our analysis below, we simply keep those early years. First, any such selection does not appear cohort-specific as we confirm with a placebo group below. Second, we did not find differential attrition based on comprehensive data from incorporation onward in Section 4 Third, we will show robustness of wage results to restricting the sample to 2006 and 2014 (the coverage years for BvD outcomes such as value added or fixed assets) in Section 6.

Additional Control Group: LLCs Secular trends in wages by incorporation date but unrelated to shared governance could mask a treatment effect. We rule out this concern by netting out incorporation time effects with a control group of unaffected legal forms (LLCs), plotted in Panel (a) in navy and hollow red triangles ${ }^{26}$ While LLC wages are lower overall, there is no visually detectable difference in the level and evolution of log wages comparing older and younger LLCs.

Cohort Graphs by Date of Incorporation Figure 4 Panel (b) plots averages of firmlevel log wages across all calendar years, but organized in more granular, quarter-ofincorporation cohorts and in a wider sample range of five rather than two years around the reform date. Stock corporations exhibit no clear shift in the wage level on either side of the policy discontinuity, neither locally nor for farther-away observations. The graph also reveals no differential trends, suggesting that a bandwidth choice is unlikely to affect an estimate of the wage effect, as we confirm below. The graph also includes a local linear regression line with a two-year bandwidth and a uniform kernel separately on either side of the policy discontinuity; we discuss the regression discontinuity results below.

We again include LLCs as a control group. Their bins are less dispersed due to the

${ }^{26}$ Section 4 showed that the reform did not shift the frequency of incorporations across legal forms, both on average and across different industries. 
substantially larger sample size. LLCs do not exhibit a trend or trend break around the policy discontinuity either.

Regression Evidence We now formally estimate treatment effect of shared governance. We start with a simple difference regression among stock corporations:

$$
Y_{f t}=\alpha+\gamma^{\text {Diff }} \cdot \mathbb{1}\left(\text { IncDate }_{f}<0\right)+X_{f t}^{\prime} \beta+\epsilon_{f t},
$$

where $Y_{f t}$ denotes the outcome for firm $f$ in year $t$ (as we stack the firm panel data) and

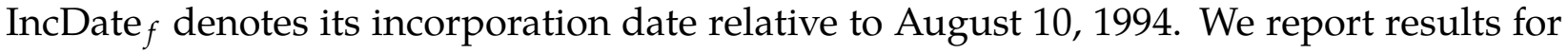
$\hat{\gamma}^{\text {Diff }}$ in Table 1. Panel A, Column (1) including year fixed effects and industry-year fixed effects as control variables $X_{f t}$. The year or industry-year fixed effects also ensure that only observations from years in which we observe both slightly older and younger stock corporations will be used for identification of the treatment effect.

Our main specification uses a two-year window around the reform. Here we find point estimates ranging between 0.025 (SE 0.039) and -0.012 (SE 0.041). The confidence intervals include zero and allow us to reject effects on mean wages larger than 0.10 or lower than -0.09 . The stability of the estimates across specifications with industry-specific and common year fixed effects is consistent with the fact that the reform did not shift industry composition, as we have documented in Section 4.

Figure 4 Panel (c) plots $\hat{\gamma}^{\text {Diff }}$ for bandwidths ranging from 6 to 60 months, with industryyear effects. The point estimates are centered around zero for bandwidths above 12 months (and slightly larger at shorter bandwidths where confidence intervals widen); we cannot reject zero effects in any of these bandwidths.

Mirroring Figure 4 Panels (a) and (b), we now formalize the use of LLCs as an untreated control group in a difference-in-differences specification to net out incorporation time, cohort, or age effects, which may otherwise confound our estimate of the treatment effect:27

$$
Y_{f t}=\alpha+\gamma^{\text {DiD }} \cdot \mathbb{1}\left(\text { IncDate }_{f}<0\right) \cdot \text { StockC }_{f}+\psi \cdot \mathbb{1}\left(\text { IncDate }_{f}<0\right)+\delta \cdot \text { StockC }_{f}+X_{f t}^{\prime} \beta+\epsilon_{f t}
$$

\footnotetext{
${ }^{27}$ Of course, LLCs and stock corporations differ along a number of dimensions (including codetermination rules, see control means in our regression tables as well as the level differences depicted in Figure4 4 Panels (a) and (b)). The identification assumption for the difference-in-differences design is not that stock corporations and LLCs do not differ in levels, but that trends are parallel, i.e. the within-legal-form difference between slightly older versus younger firms would stay constant, were it not for the 1994 reform changing the codetermination mandate in young stock corporations (but leaving these rules unchanged for the three other groups). While we cannot test this assumption in our analysis sample (because of the reform), Appendix Table A.4 does so with placebo reforms, counterfactually assuming the 1994 reform had taken place in 1996 or 1997 instead. The robustness to varying bandwidths also supports this assumption.
} 
where $\psi$ captures incorporation time effects unrelated to shared governance and $\delta$ captures differences between stock corporations and LLCs.

We report estimates of $\hat{\gamma}^{\mathrm{DiD}}$ in Table1. Panel B, Column (1) for the two-year bandwidth. Figure 4 Panel (d) plots estimates for bandwidths from 6 to 60 months. Consistent with the visual evidence in Figure 4 Panels (a) and (b), the point estimates (and standard errors) of the simple difference specifications are robust to including this second control group, at 0.017 (SE 0.039) and 0.003 (SE 0.037).

As a third approach to gauge wage effects, we implement a regression discontinuity specification, which mirrors the difference specification in Equation (1) and additionally controls for linear trends in incorporation time:

$Y_{f t}=\alpha+\gamma^{\mathrm{RD}} \cdot \mathbb{1}\left(\operatorname{IncDate}_{f}<0\right)+\delta \cdot$ IncDate $_{f}+\delta^{-} \cdot$ IncDate $_{f} \cdot \mathbb{1}\left(\right.$ IncDate $\left._{f}<0\right)+X_{f t}^{\prime} \beta+\epsilon_{f t}$

where we use day-specific incorporation date as the running variable IncDate $f$. We report results for $\hat{\gamma}^{\mathrm{RD}}$ in a two-year window of incorporations around the reform date in Table 1. Panel C, Column (1). Figure 4 Panel (b) reports a local linear specifications with a two-year bandwidth, plotting log wages against incorporation dates; Panel (e) reports the robustness of estimates to varying bandwidths. Finally, Panel (f) reports the results of donut hole specifications where we leave out observations in a radius, indicated on the $\mathrm{x}$-axis, around the reform date and extend the observations we include further away to keep a two-year window.

We find larger point estimates of 0.080 (SE 0.082) and 0.062 (SE 0.091) among stock corporations in the two-year window. The standard errors more than double in the RD specification so that the statistical power is lower. For example, the confidence interval for the specification with industry-year effects ranges from -0.114 to 0.234 .

Median Wages and Censoring To gauge the role of outliers in affecting effects on the typical worker, Column (2) of Table 1 reports effects on median rather than mean log wages. Effects remain similar, e.g., -0.013 (SE 0.043) with industry-year effects in Panel A. In Column (3), we investigate effects on the share of censored observations at the firm, i.e. workers with earnings above the social security maximum. The control mean is 0.130 . We find essentially zero effects on this outcome, between -0.004 (SE 0.020) and 0.014 (SE 0.019).

\subsection{Composition Adjustment}

Raw worker-level wage effects could capture or mask changes in worker composition. In Column (4) we therefore also report effects on log wages residualized by basic Mincerian 
controls, namely a cubic polynomial in age specific to three education groups (no training, vocational training, and university-level education). We find that the positive point estimates from raw wages drop to zero, suggesting that the wage effects captured composition effects. Moreover, precision increases. For example, in our specifications with year effects, we find estimates for $\hat{\gamma}^{\text {Diff }}$ of -0.004 (SE 0.028), for $\hat{\gamma}^{\mathrm{DiD}}$ of -0.010 (SE 0.028), and for $\hat{\gamma}^{\mathrm{RD}}$ of 0.012 (SE 0.059). Importantly, the larger point estimates in the RD specifications not controlling for Mincerian controls shrink close to zero when controlling for demographics.

\subsection{Wage Policies: AKM Firm Effects}

To further understand the effect on firms' pay policies net of worker selection, we analyze firm pay premia in specifications with worker and firm effects as in Abowd, Kramarz, and Margolis (1999), thereby controlling for all permanent worker characteristics. We estimate the fixed effects in the full Orbis-ADIAB data set before applying our sample restrictions. 2 We estimate firm level fixed effects in a rolling window of five years. We label each fiveyear window based on its midpoint, so that 1997 denotes the five-year window from 1995 to 1999. In our analysis sample, we assign firms their AKM effects starting three years after their incorporation i.e. when the first full five-year window is available.

We report results visually in Figure 5. We find that pay premia evolve similarly over time among older and younger stock corporations, and similarly for LLCs (Panel (a)). Since the levels of the AKM specifications are not comparable across years, we here normalize the AKM pay premia among older stock corporations to correspond to the average log wage in this firm group within each year (i.e. these AKM effects track the corresponding line in Figure 4 Panel (a)) and adjust the premia in the other groups accordingly. The regression discontinuity plot in Panel (b) reveals quantitatively small and statistically insignificant differences at the discontinuity among stock corporations. For all bandwidth plots, we find small, stable, and precisely estimated effects on pay premia centered around zero.

The regression results in Column (5) of Table 1 mirror the visual analysis in Figure 5. At a two-year bandwidth, we find point estimates between 0.004 (SE 0.016) and 0.023 (SE 0.031 ), ruling out firm pay premia effects above 0.084 in our most conservative specification.

We have also assessed whether worker selection as proxied by average AKM worker fixed effects is affected by shared governance and report results in Column (6) of Table 1. We find no evidence for economically significant worker selection effects with tight confidence intervals including zero in all specifications. $\sqrt{29}$

\footnotetext{
${ }^{28}$ To estimate AKM effects in the full sample, we follow Card, Heining, and Kline (2013) and drop marginal jobs, part-time employment, and wage observations below the 5 th percentile and control for window-specific cubic polynomials in potential experience by education group.

${ }^{29} \mathrm{We}$ have also assessed direct measures of worker skill in Appendix Table A.10 and can rule out large
} 


\subsection{Wage Structure}

We also analyze effects on the firm-level wage structure, as pay compression may mask wage effects (e.g., Saez, Schoefer, and Seim, 2019), and worker representation has been hypothesized to compress wages and reduce inequality inside the firm (e.g., Freeman and Medoff, 1985, p. 82-85), perhaps also through informal norms, as in the case of unions (see, e.g., Western and Rosenfeld, 2011). We report the effects on deciles of wages at the firm level for the two-year bandwidth and with industry-year effects in Figure 6 and Appendix Table A.3. In the simple difference and difference-in-differences specifications, we find similar point estimates close to zero across the deciles ranging between -0.026 (SE 0.061) and 0.024 (SE 0.063). For the RD estimates, the confidence intervals again expand, with larger point estimates for the bottom two wage deciles. (The levels of the point estimates appear positive, but recall that these estimated dropped to zero with basic composition adjustment, so our interest here is on detecting potential heterogeneity rather than interpreting the average level.) Overall, we do not detect that shared governance leads to a compression of the pay structure.

\subsection{Labor Share}

We analyze whether shared governance affects the firm-level labor share, which we calculate as the wage bill share of value added, here drawing on the BvD component of the Orbis-ADIAB data for both variables.30 We report results in Column (7) of Table 1 and find a small negative effect of around -0.03 in most specifications relative to a control mean of 0.757 . With standard errors of about the same magnitude, we can rule out labor share increases of more than 0.03 in the difference and the difference-in-differences designs. Standard errors double in the RD design with point estimates of 0.025 and -0.029 . Overall, our results indicate no substantial increases in the labor share and, if anything, point towards a larger share of compensation going to capital. We will investigate the effects on capital formation, scale, rent sharing, and profitability in the next section.

\section{What Explains the Absence of Wage Effects?}

In this section, we further investigate the absence of wage effects and potential explanations. Drawing on a simple bargaining model, we first illustrate two potentially offsetting mechanisms through which shared governance may affect wages. On the one hand, it may

shifts across skill groups.

${ }^{30}$ Since value added is not filled for all firms, we replicate the IAB wage results for the set of firms with nonmissing value added (per worker) measure in Appendix Table A.6. and find very similar results. 
increase worker bargaining power, thus increasing wages. On the other hand, the positive wage effect may be offset through hold up through which higher worker bargaining power deters capitalists' investment and thus lowers the capital stock and wages. We then empirically shed light on both of these mechanisms. We find, if anything, that board-level codetermination raises capital formation. Next, we show that shared governance has no effects on rent sharing. We conclude with an analysis of effect heterogeneity. We find that board-level codetermination does not raise wages even when collective bargaining coverage or the prevalence of works councils is low, or when surplus is high.

\subsection{Conceptual Framework}

To guide our subsequent analysis and to build intuition, we present a simple model of firm-level wage setting. Even though the institution is distinct from firm-level unions as it is, e.g., more cooperative, a natural starting point is to view shared governance as boosting worker bargaining power, which we do in the context of a canonical union bargaining model (Brown and Ashenfelter, 1986; Abowd and Lemieux, 1993). $N$ is the total size of the labor entity bargaining with the firm at hand. $b$ denotes some reduced-form flow value for those not employed in the firm (unemployment insurance or wages at a reference competitive wage). $L$ is the employment level, which we here set to be fixed at $L=\bar{L}$. Here, we take output $Y=F(L, K)$ as given, which is zero at disagreement (with zero labor). We later relax this assumption in Section 6.2 .

Wage Bargaining Wages $w$ are determined by Nash bargaining, with workers holding bargaining power $\phi$ :

$$
w^{*}=\arg \max _{w}\left\{\phi \log S^{W}(w)+(1-\phi) \log S^{F}(w)\right\},
$$

where $S^{W}=L(w-b)$ is the workforce's surplus: the inside value of the relationship $L w+(N-L) b$ minus the outside option, which is $N b$.

Firm surplus is $S^{F}=Y-w \bar{L}-c^{\prime} K$ at the bargaining stage, where the firm's outside option is repurposing or reselling capital at price $c^{\prime}$. Total surplus is $S=S^{W}+S^{F}=Y-b L-c^{\prime} K$. The Nash bargaining solution allocates surplus shares such that $S^{W}=\phi S$ or $S^{F}=(1-\phi) S$, and therefore the Nash wage $w^{*}$ is outside option $b$ plus share $\phi$ of surplus:

$$
w^{*}=\phi \cdot \frac{Y-b L-c^{\prime} K}{L}+b \text {. }
$$


Wage Effects of Shared Governance The bargaining setup suggests three channels through which shared governance can affect wages:

$$
d w^{*}=\underbrace{d \phi}_{\text {Rent Sharing }} \cdot \frac{Y-b L-c^{\prime} K}{L}+\phi \cdot \underbrace{d\left(\frac{Y}{L}\right)}_{\text {Size of the Pie }}+\underbrace{(1-\phi) \cdot d b-\phi \cdot d\left(c^{\prime} K\right)}_{\text {Implausible: Outside Options }},
$$

where $d x=x^{\mathrm{SG}}-x^{\text {No SG}}$ denotes the difference in variable $x$ between firms with and without shared governance; Equation (6) takes a total derivative and a linear approximation, thereby assuming that the effects are small (consistent with our findings at least for wages).

In the next two sections, we turn to the right hand side and decompose potential wage effects and lack thereof. We study effects on the size of the surplus pie, and specifically the capital disinvestment channel of hold-up models, in Section 6.2. In Section 6.3, we analyze effects on $d \phi$ proxied for by rent-sharing estimates. We evaluate compensating differentials or outside option shifts in Section 6.4. Finally, we also ask whether wage flexibility at the firm level may mask wage effects, in a heterogeneity analysis in Section 6.5. We discuss broader views on the institution in the conclusion.

\subsection{Do Smaller Pies and Hold-Up Effects Mask Wage Effects? $d\left(\frac{Y-b L-c^{\prime} K}{L}\right)$}

One potential mechanism that could explain the absence of wages is that shared governance may reduce the size of the pie, i.e. the surplus to be shared between workers and firms. This could work through a variety of mechanisms. Most prominently, the canonical hold-up view provides a theoretical underpinning predicting this outcome through a disinvestment channel. In that model, anticipating that labor will grab a larger share of the fruits from their investments, capitalists reduce investment in these models. Several authors have argued that unions and other forms of worker representation can be thought of as rent-extracting institutions (see, e.g., Grout, 1984; Lindbeck and Snower, 1989), and that shared governance is one of such institutions (Jensen and Meckling, 1979).

Alternative models of shared governance also have predictions for firm performance and hence wages in bargaining models, or more broadly any model in which firm size of productivity affects wages, such as wage posting models. An alternative bargaining model permits workers to jointly bargain over investment and wages. In Appendix Section C. we show that such a model can predict positive investment effects and break the holdup prediction even in a closely related bargaining model, building on (Manning, 1987). Efficient bargaining too may predict positive rather than negative scale and investment effects (Crawford, 1988). Corporate governance may be affected and differential selection or accountability of managers may lead to changes in firm scale or productivity. Alternatively, 
shared governance may affect productivity directly through information sharing, fostering worker voice, and facilitating training in specific skills (e.g., Freeman, 1980).

Firm Performance: Output and Productivity The surplus measure corresponding to our worker-level wage outcomes is per-worker surplus, so we start with value added divided by BvD-based employment (labor productivity) ${ }^{31}$

We again start by plotting raw data of this outcome, in Figure 7 Panel (a), tracking cohorts of corporations over time, sorting firms into treatment and control groups along the two-year bandwidth around the reform date. Unlike the wage outcomes, this graph starts in 2006 as it builds on the BvD component of the Orbis-ADIAB data set. Labor productivity of stock corporations incorporated before 1994 and hence with shared governance (blue line with solid circles) is above their control group's level in all years, except for two slight dips in the early years. As a placebo comparison, the figure also plots the corresponding cohort graphs for LLCs, where old and young LLCs' labor productivity essentially lies on top of each other throughout (at a lower level).

In Table 2 Column (1), we report the corresponding regression estimates for the treatment effect of board-level codetermination. The table follows the structure of Table 1 for the wage outcomes. The simple difference with year fixed effects reveals positive effects of $2.2 \%$ to $7.5 \%$, for the simple difference between old and young stock corporations as well as with LLCs as a second control group, and with year and year-industry fixed effects. The standard errors are $11-12 \%$, so the wide confidence intervals include zero.

Since the sample drops when we study value added per worker compared to the IAB-based wage outcomes in Table 1. we show that these wage results are robust to restricting the sample to the firm-year observations with non-missing value added per worker information, in Appendix Table A.6. Additionally, we report effects of placebo reforms in 1996 and 1997 on value added per worker (and on all other outcomes shown in Table 2) in Appendix Table A.4. Appendix Figure A.3 shows the corresponding RD plots, with RD regression results in Appendix Table A.7 Column (1) (and similarly for the other BvD outcomes of Table 2 discussed below). Here, confidence intervals double, such that the large negative point estimates also accommodate positive effects of around $25 \%$.

In Column (2), we also study log value added (i.e. not divided by employment), to measure the total size of the pie and because firm scale is a marker of productivity in many models (e.g., Lucas, 1978). For this much more dispersed outcome, confidence intervals

${ }^{31}$ A previous version of this paper focused on the financial BvD outcomes, and therefore drew on a larger and longer multi-source BvD sample described in Footnote 14 . The current version instead focuses on the IAB outcomes, and studies an additional, smaller, set of BvD outcomes in the smaller and shorter OrbisADIAB sample of BvD firms. The main results for capital and value added have remained robust to this alternative sample; the capital share and outsourcing effects are closer zero in the Orbis-ADIAB sample. 
double (standard errors expand to from 0.11 to 0.23 ). Point estimates are zero except for the large negative simple difference with industry-year fixed effects; this specification however converges towards zero in the difference-in-differences specification.

As less demanding measures than value added, we also present log revenue per worker and log revenue in Columns (3) and (4) of Table 2, a BvD outcome filled for considerably more firms. Point estimates are positive throughout, 0.058 to 0.177 for $\log$ revenue per worker (SEs of 0.140 to 0.154 ) and 0.159 to 0.296 for log revenue (SEs of around 0.26).

Lastly, in Columns (5) and (6), we study log employment (BvD and IAB variables respectively) as another measure of firm scale but also as the $\mathrm{BvD}$ employment measure normalizes our per-worker outcomes. The BvD variable includes those abroad; the IAB one captures employment subject to German social security and thus more relevant for codetermination thresholds (see Annuß, 2019, DrittelbG § 3, Rn. 2). We find statistically insignificant, positive effects, ranging from 0.005 to $0.092 \%$ (SEs of 0.154-0.160) for BvD employment, and 0.045-0.065 (SEs of 0.136 to 0.153 ) for IAB employment. We also find no effects on the skill structure and outsourcing as shown in Appendix Table A.10 ${ }^{32}$

We conclude that shared governance does not appear to reduce the size of the firm's pie, either in total or on a per-worker basis. While effects are noisily estimated, if anything, shared governance appears to raise surplus and firm scale proxies.

Capital Formation: Testing the Hold-Up Hypothesis We now study the effect of shared governance on capital. An influential argument against shared governance is that granting workers control rights will raise their bargaining power and wages, and thereby discourage capital formation (Grout, 1984). Prominently, Jensen and Meckling (1979) lay out the disinvestment effects of codetermination as follows:

[T] he workers will begin 'eating it up' [the firm] by transforming the assets of the firm into consumption or personal assets. [...] It will become difficult for the firm to obtain capital in the private capital markets. [...] The result of this process will be a significant reduction in the country's capital stock, increased unemployment, reduced labor income, and an overall reduction in output and welfare.

Formally, the firm invests anticipating wage rule (5), in which share $\phi$ of the marginal product of capital goes to wages, acting like a distortionary profit tax (as in Grout, 1984), 33

\footnotetext{
${ }^{32}$ We find negative point estimates throughout for the share of low-skilled workers without vocational training. We further study effects on the share of workers in outsourceable occupations (food, cleaning, security and logistics) and similarly find no evidence for firms reducing employment in these categories. We also report positive, insignificant effects on the BvD-based value-added/revenue ratio as an inverse measure of outsourcing.

${ }^{33}$ Consider a simplified two-stage setting, in which capital $K$ is purchased in stage 1 at price $c$, becomes productive in stage 2 , then fully depreciates. There is no discounting between periods. The firm chooses $K$
} 
The BvD data report capital stocks but not capital expenditures ("investment"). We start with fixed assets, which comprise tangible assets, such as buildings and equipment, and intangible assets, such as patents or trademarks. The point estimates for log fixed assets, reported in Column (7) of Table 2, are large and positive, around 0.431 to 0.546 , and relatively stable across specifications, with large standard errors of $0.317-0.352$, such that confidence intervals include zero. We further study tangible fixed assets in Column (8), documenting large positive but again insignificant effects ranging from 0.270 to 0.490 (SEs of 0.196-0.224).

Since these scale outcomes are potentially skewed, we additionally normalize them by BvD employment, as with value added. That is, we estimate effects on the capitallabor ratio. Effects on log fixed assets per worker, reported in Column (9) are of similar magnitude ranging between 0.443 and 0.587 , but are now more precisely estimated with standard errors dropping to $0.250-0.273$; as a result, the positive effects are statistically significant at the $5 \%(10 \%)$ level for the specifications with industry-year effects (year effects). Column (10) reports effects on log tangible assets per worker, for which normalizing by employment leaves point estimates similar but reduces standard errors as well.

These non-negative capital effects imply that either shared governance does not depress capital formation through hold-up. Or, the hold-up mechanism is overturned by counteracting forces that crowd in investment. Our analysis of effects on rent sharing will allow us to shed further light on the former mechanism.nc

As we drop some firms for this analysis using BvD outcomes (relative to our analysis of wages), Appendix Table A.5 shows that the wage results from Table 1 are robust to restricting the sample to firm-year observations with non-missing fixed asset information. Again, Appendix Table A.4 reports results from placebo reforms in 1996 and 1997. We also ballpark that the large implied capital effects can be considered consistent with the moderate value added effects in a Cobb-Douglas constant-returns production framework. ${ }^{34}$

maximizing expected profits, $\pi(w, \bar{L}, K)=F(K, \bar{L})-w \bar{L}-c K$, by equalizing the marginal cost of purchasing it, $c$, with its marginal benefit (output net of wage effects): $F_{K}\left(\bar{L}, K^{*}\right)=c+\bar{L} \frac{\partial w^{*}}{\partial K}=c+\phi\left(F_{K}\left(\bar{L}, K^{*}\right)-c^{\prime}\right)=$ $c+\left(c-c^{\prime}\right)\left[\frac{\phi}{1-\phi}\right]$. Capital investment involves two considerations. First, the marginal unit of capital raises output by $F_{K}$, but comes at cost $c$. Second - the core of the hold-up mechanism - workers grab share $\phi$ of surplus in stage 2. At that stage, capital has value $c^{\prime} \leq c$. Underinvestment $\left(F_{k}>c\right)$ emerges as long as wage bargaining power $\phi>0$ and capital is at least partially sunk $\left(c^{\prime}<c\right)$. As a result, shared governance may exacerbate hold-up, and reduce investment to the extent that it boosts worker bargaining power $\phi$ in wage negotiations: $\frac{d K^{*}}{d \phi}=\frac{1}{F_{K K}\left(\bar{L}, K^{*}\right)}\left(c-c^{\prime}\right) \frac{1}{(1-\phi)^{2}}<0$, the capital/labor ratio, and hence per-worker surplus. Appendix Section $C$ shows that these predictions extend to the case with endogenous labor.

${ }^{34}$ Consistent with the increase in capital intensity, we also documented a negative but insignificant decline in the labor income share in Table 1 Column (7), although, for example with Cobb-Douglas the capital income shared can remain constant even if capital intensity increases such as in response to factor price shifts. Regarding the labor productivity effects, the capital share in our sample is 0.272 on average (one minus control mean of labor share in Table 1 Column (7)), which in a Cobb-Douglas constant-returns production function represents the elasticity of value added per worker to the capital-labor ratio (holding 
Assessment of Hold-Up Theory Shared governance does not appear to induce firms to become smaller or less productive. The data specifically reject the prominent disinvestment prediction of the hold-up and agency cost views of shared governance (see, e.g., Jensen and Meckling, 1979). A priori, such disinvestment could have rationalized the absence of wage increases or even led to wage reductions.

Instead, the findings on firm performance align more with richer perspectives on industrial relations and capital-labor interactions. For example, worker representatives may have longer-term perspectives than shareholders or executives. Or, shared governance may facilitate cooperation and long-term contracts between owners, managers and the workforce, perhaps by institutionalizing communication channels and repeated interactions. These views are consistent with anecdotal evidence for worker representatives' self-described objectives to boost firm scale and investment, for example:

[S]hared governance per se opposes short-term shareholder interests. The focus [of shared governance] is on the long-term safeguarding of the company through investments and innovations with participation of the employees $[\ldots] \cdot[35$

Berthold Huber, Worker Supervisory Board Representative, Siemens

Similarly, surveys of plant-level agreements have found that workers often push for guarantees of investments in existing plants when negotiating (Rehder. 2003).

Alternatively, the institution may lead to agency conflicts inside the firm such as facilitating managers' empire building, with resources being locked into fixed capital at the expense of dividends - so that capitalists may not voluntarily adopt codetermination (Jensen and Meckling, 1979). We study profitability effects below.

\subsection{Does Shared Governance Boost Rent Sharing? $d \phi$}

We directly assess the degree to which workers' bargaining power in wage setting may have shifted in shared-governance firms. We do so by studying firm-level rent sharing elasticities and find no shifts induced by shared governance. The motivation for the

efficiency constant). Hence, a $50 \%$ increase in fixed assets times a capital share of 0.272 would lead to a $13.6 \%$ predicted increase of value added per worker, close to the two higher point estimates among the four specifications in Table 2 Column (1), and within the confidence interval of all estimates. The magnitude of the capital point estimates also falls within the range of estimated firm-level investment responses to other corporate governance variation. In the context of Compustat firms, Bertrand and Schoar (2003) find that manager style effects on firm-level investment (to capital ratio) differ by $20 \log$ points between the 25th and 75th percentile of managers. Pan, Wang, and Weisbach (2016) find a 29\% (6.9/24) effect on investment over the course of a new CEO's tenure comparing the first three years to the later years. In the context of smaller, Danish firms, Bennedsen et al. (2007) find an effect of death-driven successions of CEOs by family members rather than outside directors reduces assets by 0.30 (SE 0.24) in family firms.

${ }^{35}$ Source: Frankfurter Allgemeine Zeitung, November 15, 2004, Nr. 267, p. 13, translation by authors. 
analysis is that in bargaining settings, workers can capture firm-specific shifts in surplus, to a degree that is guided by worker bargaining power $\phi$ :

$$
\frac{\partial w^{*}}{\partial S / L}=\phi
$$

The rent sharing estimation therefore permits us to directly test whether shared governance shifts worker bargaining power in wage setting (as in Jäger et al., forthcoming, who also include a meta analysis of the implied parameters). In practice, we estimate standard rent sharing elasticities that use variation in surplus arising from value added per worker, i.e. $\frac{\partial w^{*}}{\partial Y / L} \frac{Y / L}{w}=\phi \frac{Y / L}{w}$. We have found no effects on wages or the labor share, so we can plausibly go from the elasticity to the bargaining interpretation.

Shared Governance and Rent Sharing In Figure 8, we plot the relationship between wages to value-added per worker. Specifically, we use our AKM firm fixed effects as a measure of composition-adjusted wage policies of firms on the y-axis, and firms' sample average of log value added per worker on the x-axis. Our sample is firms incorporated within two years around the reform. The slope between these two variables traces out the rent-sharing elasticity. This slope is 0.067 (SE 0.018) for young shareholder corporations not subject to the mandate ${ }^{36}$ Comparing these firms with their slightly older peers subject to the mandate, we detect no difference in rent sharing induced by shared governance. The simple difference estimate is 0.010 (SE 0.026). We find a difference-in-differences estimate of 0.007 (SE 0.022) using LLCs as a second control group, ruling out increases in the rentsharing elasticity of more than 0.05. ${ }^{37}$ Consequently, we find no evidence for workers capturing a larger part of output when they have board representation - a result consistent with and perhaps underlying the absence of hold-up patterns in capital formation.

Reconciling Wage and Value Added Effects Finally, we assess whether the wage and value added effects can be rationalized with rent-sharing elasticities. The largest effect on value added per worker in Table 2 is 0.075 . Together with the rent-sharing elasticity of 0.067 reported in Figure 8 among young stock corporations, the largest value added per worker point estimate implies a wage increase of $0.075 \times 0.067 \approx 0.005$. By contrast,

\footnotetext{
${ }^{36}$ In Appendix Figure A.4 we plot the data for the pooled analysis sample. We estimate an elasticity of 0.084 (SE 0.004). While no previous worker-and-firm-level rent-sharing estimates for Germany have been reported (for lack of matched firm and worker data), the elasticity is similar to those documented in other countries (Card et al. 2018; Jäger et al., forthcoming) and to estimates in the German context based on establishment-level survey data (Gürtzgen, 2009| Hirsch and Müller. forthcoming).

${ }^{37}$ The DiD estimate is the coefficient on the interaction between log value added per worker and an indicator for stock corporations incorporated before August 10, 1994. The model also includes base effects for cohort and legal form, each interacted with value added.
} 
even when using the upper confidence interval of the value added per worker effects of around 0.3, the predicted wage effect purely from the potential increase in surplus would be $0.3 \times 0.067 \approx 0.020$. These predicted effects are strikingly similar to the point estimates for the effect on firm pay premia in Column (5) of Table 1 range between 0.004 to 0.023 , with tight confidence intervals especially for the difference and difference-indifferences specifications (SEs of around 0.015). That is, workers may benefit from the larger capital stock and larger pie through the standard rent-sharing channel, which, by itself and absent increases in rent sharing, however, would imply small wage gains. Our rent-sharing estimates revealed no large effects on this aspect of wage setting.

Profitability We find no evidence of profit effects (see Appendix Table A.8), which is consistent with the absence of measurable effects on wages, rent sharing and labor shares. This finding is also consistent with an absence of strategic delay or rushed entrance of firms before the cutoff documented in Section 4, which would have been predicted if shared governance were very costly or profitable (e.g., Jensen and Meckling, 1979).

\subsection{Non-Wage Amenities, Compensating Differentials, and Outside Op- tions: Effects on Tenure and Separations}

Shared governance may raise the amenity value of staying at the firm and such an increase may be offset in lower wages through compensating differentials (Kim, Maug, and Schneider, 2018). If shared governance led to higher worker rents, even if those manifested themselves in non-monetary form rather than wages, we would see an increase in workers' willingness to stay in the firm and hence an increase in average tenure, even if wages were not or even negatively affected. Lastly, in principle, shared governance may affect wage-relevant outside options (as in Jäger et al., forthcoming), though we find it difficult to formulate plausible scenarios, such as shifts in training in general human capital or unemployment durations.

We test these alternative mechanisms by studying tenure and separations in Appendix Table A.10 Columns (6) through (8), studying log tenure, level of tenure in years, and the annual separation rate, among the full-time workers that make up our wage analysis sample. Effects on tenure are statistically insignificant but positive in most specifications. In the simple difference specifications, point estimates suggest 0.071 and 0.077 increases in log tenure (SEs of around 0.05 ) and 0.235 and 0.332 years of additional tenure (SEs of 0.279 and 0.301 ) with year and industry-year effects respectively. In the DiD specifications (which would also account for potential mechanical effects from lower censoring of tenure in older firms), effects fall towards zero and slightly negative (with similar SEs). We find 
essentially zero effects on the annual separation rate $(-0.001$ to -0.009 with SEs of around 0.0006 to 0.016 , with control means of 0.095).

Therefore, the results do not suggest that shared governance raises job quality aspects valued by workers. Additionally, studying turnover is also another validation revealedpreference check of the absence of wage premia. Finally, our results on turnover also do not provide support for the voice-exit hypothesis, by which information sharing and exercise of worker voice could have reduced turnover (Hirschman, 1970; Freeman, 1980).

\subsection{Heterogeneity Analysis: Wage Flexibility, Collective Bargaining, High-Rent Industries, and Works Councils}

Here, we analyze heterogeneity of wage affects across pockets of the labor market. To this end, we calculate characteristics at the three digit industry level, for example, collective bargaining agreement (CBA) coverage, and then analyze treatment effects depending on whether the firm is in an industry cell above or below the median (allowing for all relevant base and interaction effects). For the CBA and works council variables, our analysis draws on the IAB Establishment Panel (a representative survey of establishments) from 2008 onwards (when the NACE Rev. 2 codes permit a direct mapping to the BvD NACE code). We report results in Figure 9, including means of the sorting (heterogeneity) variables separately for the above and below median samples of stock corporations in a two-year bandwidth around the reform. Panel (a) does so for firm-level mean log wages, and Panel (b) for AKM firm fixed effects. Appendix Table A.11 reports the full regression results.

Collective Bargaining Coverage and Observed Wage Differentiation A potential reason why wage effects are close to zero may be that CBAs may leave little room for decentralized wage setting at the firm level. Centralized wage setting may curb rent extraction and thus reduce hold-up problems (Freeman and Lazear, 1995; Acemoglu, 2001). In the German context, CBA coverage has been associated with lower responsiveness of establishmentlevel wages to the presence of works councils and to establishment-level value added, as well as with lower dispersion of establishment wage fixed effects Hübler and Jirjahn (2003); Gürtzgen (2009); Hirsch and Müller (forthcoming).

First, we sort firms into their industries by (industry- or firm-specific) CBA coverage using the IAB Establishment Panel. There is substantial heterogeneity in CBA coverage, namely $42.5 \%$ below and of $79.7 \%$ above the median. This wide dispersion and the existence of pockets with low coverage reflect a trend towards decentralization since the 1990s (Brändle, Heinbach, and Maier. 2011; Dustmann et al. 2014; Kügler, Schönberg, and Schreiner, 2018). 
Analyzing heterogeneity across industries with low and high coverage, we find no evidence that higher CBA coverage masks wage effects. We detect no statistically significant effects in the two subsamples in any of the specifications for either mean log wages nor AKM firm fixed effects. In the simple difference and difference-in-differences analyses, low-coverage cells exhibit close to zero point estimates of 0.003 (SE 0.022) and -0.002 (SE 0.018); in the regression discontinuity specification, the point estimate is slightly larger but with wider standard errors (0.045, SE 0.041).

Second, we study heterogeneity in the fraction of firms with "binding" CBA coverage in an industry (having a CBA and not paying above-CBA wages). The baseline levels above and below the median are very low at 0.254 and 0.108 , respectively, again reflecting substantial scope for localized wage setting. We again find no evidence for larger wage effects in cells of the labor market where few firms have a binding CBA.

Third, we draw on measures of dispersion of the AKM firm pay premia we estimated in Section 5, and calculate their standard deviation within a 3-digit industry to capture scope for firm-level wage setting. We again find no evidence that firms in industries with more decentralized wages experience larger wage effects of board-level codetermination.

Prevalence of Works Councils We calculate heterogeneity in the effect by the prevalence of establishment-level works councils at the industry level. On the one hand, board-level codetermination may have smaller effects when establishment-level representation in the form of works councils is already prevalent as the institutions may partially duplicate each other. On the other hand, observers of industrial relations in Germany have argued for a complementarity between establishment- and board-level codetermination (as board representatives can also serve as works councilors, see, e.g., Streeck, 1984; Paster, 2012). We find substantial baseline variation in the prevalence of works councils with an average prevalence of $57.2 \%$ and $83.5 \%$, respectively, in cells above and below the median.

Our results leave some room for larger wage effects in industries with higher works council coverage. In the simple difference and difference-in-differences specifications, the point estimates for wage effects are larger in industries with a higher prevalence, at 0.097 (SE 0.060) and 0.116 (SE 0.057). But the effects on AKM pay premia are smaller at 0.028 (SE 0.023) and 0.040 (SE 0.023). We find the mirror image of negative but insignificant effects for cells below the median. In the regression discontinuity specification, we find smaller effects on both outcomes at 0.020 (SE 0.120) for log wages and -0.010 (SE 0.039) for AKM pay premia. Overall, we do not find sharp evidence for a complementarity or a substitutability between works councils and board-level codetermination, but the weight of the evidence speaks, if anything, more for a complementarity in terms of wage effects. 
Proxies for Surplus Finally, we assess heterogeneity in the effect by the level of surplus per worker. At an extreme, in industries with low or no rents, increases in worker bargaining power may not be consequential because wages are determined by outside options rather than reflecting the surplus from the employment relationship. We consider three surplus proxies at the industry level: log value added per worker, average AKM pay premium, and average tenure (revealed-preference measure of surplus). Figure 9 reveals no significant heterogeneity in the wage effects across these surplus proxies.

\section{Conclusion}

Worker representation on company boards does not appear to affect wage setting in detectable ways such as by raising bargaining power. We have studied a cohort- and legalform-based reform in Germany that abolished this form of shared governance in some firms but permanently preserved it in others. Our main results are that, first, worker representation on boards does not appear to affect wage setting, as measured by average wages, firms' wage policies, the wage structure within firms, or the degree of rent sharing. Second, the data reject the prominent disinvestment prediction of the hold-up and agency cost views of shared governance (see, e.g., Jensen and Meckling, 1979), which could have in principle rationalized the absence of wage effects. Third, we do not find negative profitability effects, although we caution that our data do not contain dividend payouts or firm valuations. Fourth, heterogeneity analyses rule out that sectoral collective bargaining, the presence of works councils or low surplus masked potential wage effects $\sqrt{38}$ Hence, our findings may extend beyond institutional settings similar to Germany's.

We close by reflecting on aspects of the institution we study itself. First, owner representatives always retain the majority of board seats in the German codetermination system (and in other countries with codetermined boards). Even theories that do grant minority factions some real authority (Aghion and Tirole, 1997) would do so only in matters unimportant to capital - a domain that plausibly excludes wage setting. Second, in the dual board structure, the supervisory boards do not have direct influence on wage setting, although we reviewed a number of plausible channels in the introduction, 39 Third, unlike the role of unions in an adversarial system, de jure the fiduciary duty of worker represen-

\footnotetext{
${ }^{38}$ While we did not find that board representation affected wage setting and found if anything larger incremental effects in cells with more works councils, our study does speak to the potential independent wage effects of plant-level works councils, the other facet of shared governance.

${ }^{39}$ The evidence is consistent with limited influence of gender quotas for board seats on the gender wage gap as in Bertrand et al. (2018); Maida and Weber (2019). Yet, these studies affected the composition of capital representatives along a demographic dimension. Other settings with unitary board structures as the dominant governance form, such as in Finland, permit worker representation also on board of directors and in management bodies.
} 
tatives on the board lies with the corporation and hence may be more aligned with the capital owners. In fact, it has been argued that worker board representatives are typically moderate actors and that minority board representation itself may have contributed to overall more cooperative labor relations in Germany (Thelen, 1991). 


\section{References}

Abowd, John, Francis Kramarz, and David Margolis. 1999. "High Wage Workers and High Wage Firms." Econometrica 67 (2):251-333.

Abowd, John and Thomas Lemieux. 1993. "The Effects of Product Market Competition on Collective Bargaining Agreements: The Case of Foreign Competition in Canada." The Quarterly Journal of Economics 108 (4):983-1014.

Acemoglu, Daron. 2001. "Good Jobs versus Bad Jobs." Journal of labor Economics 19 (1):1-21.

Addison, John. 2009. The Economics of Codetermination: Lessons from the German Experience. New York: Palgrave MacMillan.

Addison, John, Thorsten Schank, Claus Schnabel, and Joachim Wagner. 2007. “Do Works Councils Inhibit Investment?" ILR Review 60 (2):187-203.

Addison, John, Claus Schnabel, and Joachim Wagner. 2001. “Works Councils in Germany: their Effects on Establishment Performance." Oxford Economic Papers 53 (4):659-694.

Addison, John, Paulino Teixeira, and Thomas Zwick. 2010. “German Works Councils and the Anatomy of Wages." ILR Review 63 (2):247-270.

Aghion, Philippe and Jean Tirole. 1997. "Formal and Real Authority in Organizations." Journal of Political Economy 105 (1):1-29.

Albach, Horst, Christiane Corte, Rolf Friedewald, Marcus Lutter, and Wolf Richter. 1988. Deregulierung des Aktienrechts: das Drei-Stufen-Modell: ein Entwurf zur Modifizierung des Aktienrechts im Hinblick auf personalistische Gesellschaftsstrukturen und einen erleichterten Börsenzugang. Verlag Bertelsmann-Stiftung, Gütersloh.

Annuß, Georg. 2019. Münchener Kommentar zum Aktiengesetz, vol. 2. C. H. Beck, 5 ed.

Antoni, Manfred, Katharina Koller, Marie-Christine Laible, and Florian Zimmermann. 2018. "Orbis-ADIAB: From Record Linkage Key to Research Dataset." FDZMethodenreport 04/2018 (en). Editors Rainer Schnell, Manfred Antoni .

Autor, David, David Mindell, and Elisabeth Reynolds. 2019. “The Work of the Future: Shaping Technology and Institutions."

Bennedsen, Morten, Kasper Meisner Nielsen, Francisco Perez-Gonzalez, and Daniel Wolfenzon. 2007. "Inside the Family Firm: The Role of Families in Succession Decisions and Performance." The Quarterly Journal of Economics 122 (2):647-691.

Bersch, Johannes, Sandra Gottschalk, Bettina Müller, and Michaela Niefert. 2014. "The Mannheim Enterprise Panel (MUP) and Firm Statistics for Germany." ZEW-Centre for European Economic Research Discussion Paper (14-104).

Bertrand, Marianne, Sandra Black, Sissel Jensen, and Adriana Lleras-Muney. 2018. “Breaking the Glass Ceiling? The Effect of Board Quotas on Female Labour Market Outcomes in Norway." The Review of Economic Studies 86 (1):191-239.

Bertrand, Marianne and Antoinette Schoar. 2003. "Managing With Style: The Effect of Managers on Firm Policies." The Quarterly Journal of Economics 118 (4):1169-1208. 
Brändle, Tobias, Wolf Dieter Heinbach, and Michael Maier. 2011. “Tarifliche Öffnung in Deutschland: Ausmaß, Determinanten, Auswirkungen." Zeitschrift für Arbeitsmarktforschung 44 (1):163-172.

Brown, James and Orley Ashenfelter. 1986. “Testing the Efficiency of Employment Contracts." Journal of Political Economy 94 (3, Part 2):S40-S87.

Card, David, Ana Rute Cardoso, Jörg Heining, and Patrick Kline. 2018. "Firms and Labor Market Inequality: Evidence and Some Theory." Journal of Labor Economics 36 (S1):S13S70.

Card, David, Francesco Devicienti, and Agata Maida. 2014. "Rent-Sharing, Holdup, and Wages: Evidence from Matched Panel Data." Review of Economic Studies 81 (1):84-111.

Card, David, Jörg Heining, and Patrick Kline. 2013. "Workplace Heterogeneity and the Rise of West German Wage Inequality." The Quarterly Journal of Economics 128 (3):967-1015.

Connolly, Robert, Barry Hirsch, and Mark Hirschey. 1986. “Union Rent Seeking, Intangible Capital, and Market Value of the Firm." The Review of Economics and Statistics 68 (4):567577.

Crawford, Vincent. 1988. "Long-Term Relationships Governed by Short-Term Contracts." The American Economic Review 78 (3):485-499.

Dustmann, Christian, Bernd Fitzenberger, Uta Schönberg, and Alexandra Spitz-Oener. 2014. "From Sick Man of Europe to Economic Superstar: Germany's Resurgent Economy." Journal of Economic Perspectives 28 (1):167-88.

Fischer, Gabriele, Florian Janik, Dana Müller, Alexandra Schmucker et al. 2008. "The IAB Establishment Panel-from Sample to Survey to Projection." FDZ Methodenreport 1:2008.

FitzRoy, Felix R and Kornelius Kraft. 1993. "Economic Effects of Codetermination." The Scandinavian Journal of Economics 95 (3):365-375.

Freeman, Richard. 1980. "The Exit-Voice Tradeoff in the Labor Market: Unionism, Job Tenure, Quits, and Separations." The Quarterly Journal of Economics 94 (4):643-673.

Freeman, Richard and Edward Lazear. 1995. "An Economic Analysis of Works Councils." In Works Councils: Consultation, Representation, Cooperation in Industrial Relations, edited by Joel Rogers and Wolfgang Streeck. NBER Comparative Labor Markets Series.

Freeman, Richard and James Medoff. 1985. "What Do Unions Do?" Industrial and Labor Relations Review 38 (2):244-263.

Fuest, Clemens, Andreas Peichl, and Sebastian Siegloch. 2018. “Do Higher Corporate Taxes Reduce Wages? Micro Evidence from Germany." American Economic Review 108 (2):393418.

Gold, Michael. 2011. “Taken on Board': An Evaluation of the Influence of Employee Board-Level Representatives on Company Decision-Making across Europe." European Journal of Industrial Relations 17 (1):41-56.

Gold, Michael, Norbert Kluge, and Aline Conchon. 2010. 'In the Union and on the Board': 
Experiences of Board-level Employee Representatives Across Europe. European Trade Union Institute (ETUI).

Gorton, Gary and Frank Schmid. 2004. "Capital, Labor, and the Firm: A Study of German Codetermination." Journal of the European Economic Association 2 (5):863-905.

Grout, Paul. 1984. "Investment and Wages in the Absence of Binding Contracts: A Nash Bargaining Approach." Econometrica 52 (2):449-460.

Gürtzgen, Nicole. 2009. “Rent-Sharing and Collective Bargaining Coverage: Evidence from Linked Employer-Employee Data." Scandinavian Journal of Economics 111 (2):323-349.

Hall, Peter and David Soskice. 2001. Varieties of Capitalism: The Institutional Foundations of Comparative Advantage. Oxford University Press.

Hirsch, Barry. 2004. "What Do Unions Do for Economic Performance?" Journal of Labor Research 25 (3):415-455.

Hirsch, Boris and Steffen Müller. forthcoming. "Firm Wage Premia, Industrial Relations, and Rent Sharing in Germany." ILR Review .

Hirschman, Albert. 1970. Exit, Voice, and Loyalty: Responses to Decline in Firms, Organizations, and States, vol. 25. Harvard University Press.

Hübler, Olaf and Uwe Jirjahn. 2003. "Works Councils and Collective Bargaining in Germany: the Impact on Productivity and Wages." Scottish Journal of Political Economy 50 (4):471-491.

Jäger, Simon and Jörg Heining. 2019. “How Substitutable Are Workers? Evidence from Worker Deaths." Working Paper.

Jäger, Simon, Benjamin Schoefer, Samuel Young, and Josef Zweimüller. forthcoming. "Wages and the Value of Nonemployment." Quarterly Journal of Economics .

Jensen, Michael and William Meckling. 1979. "Rights and Production Functions: An Application to Labor-Managed Firms and Codetermination." Journal of Business 52 (4):469-506.

Kim, Han, Ernst Maug, and Christoph Schneider. 2018. "Labor Representation in Governance as an Insurance Mechanism." Review of Finance 22 (4):1251-1289.

Kügler, Alice, Uta Schönberg, and Ragnhild Schreiner. 2018. "Productivity Growth, Wage Growth and Unions." In Price and Wage-Setting in Advanced Economies, vol. 2018. ECB, 215-247.

Lee, David and Alexandre Mas. 2012. "Long-Run Impacts of Unions on Firms: New Evidence From Financial Markets, 1961-1999." The Quarterly Journal of Economics 127 (1):333378.

Lindbeck, Assar and Dennis Snower. 1989. The Insider-Outsider Theory of Employment and Unemployment. MIT Press.

Lucas, Robert. 1978. "On the Size Distribution of Business Firms." The Bell Journal of Economics 9 (2):508-523. 
Machin, Stephen and Sushil Wadhwani. 1991. "The Effects of Unions on Investment and Innovation: Evidence from WIRS." The Economic Journal 101 (405):324-330.

Maida, Agata and Andrea Weber. 2019. "Female Leadership and Gender Gap within Firms: Evidence from an Italian Board Reform." CEPR Discussion Paper No. DP13476 .

Malcomson, James. 1983. "Trade Unions and Economic Efficiency." The Economic Journal 93:51-65.

Manning, Alan. 1987. “An Integration of Trade Union Models in a Sequential Bargaining Framework." The Economic Journal 97 (385):121-139.

McCrary, Justin. 2008. "Manipulation of the Running Variable in the Regression Discontinuity Design: A Density Test." Journal of Econometrics 142 (2):698-714.

McGaughey, Ewan. 2017. “The Codetermination Bargains: The History of German Corporate and Labour Law." Columbia Journal of European Law 23 (1):135-176.

Müller, Steffen and Jens Stegmaier. 2020. “Why Is There Resistance to Works Councils in Germany? An Economic Perspective." Economic and Industrial Democracy 41 (3):540-561.

Pan, Yihui, Tracy Yue Wang, and Michael Weisbach. 2016. "CEO Investment Cycles." The Review of Financial Studies 29 (11):2955-2999.

Paster, Thomas. 2012. “Do German Employers Support Board-level Codetermination? The Paradox of Individual Support and Collective Opposition." Socio-Economic Review 10 (3):471-495.

Piketty, Thomas. 2020. Capital and Ideology. Harvard University Press.

Raiser, Thomas, Rüdiger Veil, and Matthias Jacobs. 2015. Mitbestimmungsgesetz und Drittelbeteiligungsgesetz. Walter de Gruyter GmbH \& Co KG.

Rapp, Marc Steffen, Michael Wolff, Jan Hennig, and Iuliia Udoieva. 2019. “Mitbestimmung im Aufsichtsrat und ihre Wirkung auf die Unterenhmensführung: Eine empirische Analyse vor dem Hintergrund der Finanz-und Wirtschaftskrise." Study Nr. 424, HansBöckler-Stiftung .

Redeker, Nils. 2019. "The Politics of Stashing Wealth: The Demise of Labor Power and the Global Rise of Corporate Savings." Center for Comparative and International Studies (CIS) .

Rehder, Britta. 2003. Betriebliche Bündnisse für Arbeit in Deutschland: Mitbestimmung und Flächentarif im Wandel. Campus Verlag.

Saez, Emmanuel, Benjamin Schoefer, and David Seim. 2019. "Payroll Taxes, Firm Behavior, and Rent Sharing: Evidence from a Young Workers' Tax Cut in Sweden." American Economic Review 109 (5):1717-63.

Schawilye, Ramona, Eduard Gaugler, and Detlef Keese. 1999. "Das Gesetz für kleine Aktiengesellschaften und zur Deregulierung des Aktienrechts." In Die kleine AG in der betrieblichen Praxis. Springer, 1-10.

Schnabel, Claus and Joachim Wagner. 1996. “Ausmaß und Bestimmungsgründe der Mit- 
gliedschaft in Arbeitgeberverbänden: eine empirische Untersuchung mit Firmendaten." Industrielle Beziehungen/The German Journal of Industrial Relations 3 (4):293-306.

Scholz, Robert and Sigurt Vitols. 2019. "Board-Level Codetermination: A Driving Force for Corporate Social Responsibility in German Companies?" European Journal of Industrial Relations 25 (3):233-246.

Steger, Thomas. 2011. "Context, Enactment and Contribution of Employee Voice in the Boardroom: Evidence From Large German Companies." International Journal of Business Governance and Ethics 6 (2):111-134.

Streeck, Wolfgang. 1984. "Co-Determination: The Fourth Decade." In International Perspectives of Organizational Democracy. John Wiley \& Sons.

Svejnar, Jan. 1981. "Relative Wage Effects of Unions, Dictatorship and Codetermination: Econometric Evidence From Germany." The Review of Economics and Statistics 63:188-197.

Thelen, Kathleen Ann. 1991. Union of Parts: Labor Politics in Postwar Germany. Cornell University Press.

Western, Bruce and Jake Rosenfeld. 2011. “Unions, Norms, and the Rise in US Wage Inequality." American Sociological Review 76 (4):513-537.

Winkler, Heinrich August. 1998. Weimar 1918-1933: Die Geschichte der ersten deutschen Demokratie. CH Beck. 


\section{Tables}

Table 1: Effect of Shared Governance on Wages

\begin{tabular}{|c|c|c|c|c|c|c|c|}
\hline & $\begin{array}{l}\text { Log Wage, } \\
\text { Mean } \\
\text { (1) }\end{array}$ & $\begin{array}{l}\text { Log Wage, } \\
\text { p50 } \\
\text { (2) }\end{array}$ & $\begin{array}{l}\% \text { Above SocSec } \\
\text { Maximum } \\
\text { (3) }\end{array}$ & $\begin{array}{c}\text { Log Wage, } \\
\text { Mincer Resid. } \\
\text { (4) }\end{array}$ & $\begin{array}{l}\text { AKM Firm } \\
\text { Fixed Effect } \\
\text { (5) }\end{array}$ & $\begin{array}{l}\text { AKM Worker } \\
\text { Fixed Effect } \\
(6)\end{array}$ & $\begin{array}{l}\text { Labor } \\
\text { Share } \\
(7)\end{array}$ \\
\hline \multicolumn{8}{|c|}{ Panel A: Difference Design (Stock Corporations) } \\
\hline Year FE & $\begin{array}{c}0.025 \\
(0.039)\end{array}$ & $\begin{array}{c}0.037 \\
(0.043)\end{array}$ & $\begin{array}{c}0.014 \\
(0.019)\end{array}$ & $\begin{array}{l}-0.004 \\
(0.028)\end{array}$ & $\begin{array}{c}0.011 \\
(0.015)\end{array}$ & $\begin{array}{c}0.009 \\
(0.021)\end{array}$ & $\begin{array}{l}-0.029 \\
(0.034)\end{array}$ \\
\hline Industry-Year FE & $\begin{array}{c}-0.012 \\
(0.041)\end{array}$ & $\begin{array}{c}-0.013 \\
(0.043)\end{array}$ & $\begin{array}{l}-0.004 \\
(0.020)\end{array}$ & $\begin{array}{l}-0.025 \\
(0.030)\end{array}$ & $\begin{array}{c}0.004 \\
(0.016)\end{array}$ & $\begin{array}{l}-0.021 \\
(0.018)\end{array}$ & $\begin{array}{l}-0.034 \\
(0.035)\end{array}$ \\
\hline \multicolumn{8}{|c|}{ Panel B: Difference-in-Differences Design (Stock Corporations + LLC Control Group) } \\
\hline Year FE & $\begin{array}{c}0.017 \\
(0.039)\end{array}$ & $\begin{array}{c}0.028 \\
(0.043)\end{array}$ & $\begin{array}{c}0.014 \\
(0.019)\end{array}$ & $\begin{array}{l}-0.010 \\
(0.028)\end{array}$ & $\begin{array}{c}0.010 \\
(0.015)\end{array}$ & $\begin{array}{c}0.006 \\
(0.021)\end{array}$ & $\begin{array}{l}-0.035 \\
(0.035)\end{array}$ \\
\hline Industry-Year FE & $\begin{array}{c}0.003 \\
(0.037)\end{array}$ & $\begin{array}{c}0.003 \\
(0.040)\end{array}$ & $\begin{array}{c}0.004 \\
(0.017)\end{array}$ & $\begin{array}{c}-0.018 \\
(0.028)\end{array}$ & $\begin{array}{c}0.010 \\
(0.015)\end{array}$ & $\begin{array}{l}-0.016 \\
(0.018)\end{array}$ & $\begin{array}{l}-0.033 \\
(0.033)\end{array}$ \\
\hline \multicolumn{8}{|c|}{ Panel C: Regression Discontinuity Design (Stock Corporations) } \\
\hline Year FE & $\begin{array}{c}0.080 \\
(0.082)\end{array}$ & $\begin{array}{c}0.049 \\
(0.089)\end{array}$ & $\begin{array}{c}0.007 \\
(0.039)\end{array}$ & $\begin{array}{c}0.012 \\
(0.059)\end{array}$ & $\begin{array}{c}0.023 \\
(0.031)\end{array}$ & $\begin{array}{l}-0.010 \\
(0.042)\end{array}$ & $\begin{array}{l}-0.029 \\
(0.069)\end{array}$ \\
\hline Industry-Year FE & $\begin{array}{c}0.062 \\
(0.091)\end{array}$ & $\begin{array}{c}0.045 \\
(0.096)\end{array}$ & $\begin{array}{c}0.013 \\
(0.045)\end{array}$ & $\begin{array}{l}-0.010 \\
(0.069)\end{array}$ & $\begin{array}{c}0.010 \\
(0.034)\end{array}$ & $\begin{array}{c}0.006 \\
(0.042)\end{array}$ & $\begin{array}{c}0.025 \\
(0.067)\end{array}$ \\
\hline $\begin{array}{l}\text { Control Mean: Stock Cs } \\
N \text {, Stock Cs } \\
N \text {, Firm-Years Stock Cs }\end{array}$ & $\begin{array}{c}4.576 \\
229 \\
3,179\end{array}$ & $\begin{array}{c}4.672 \\
229 \\
3,179\end{array}$ & $\begin{array}{c}0.130 \\
229 \\
3,179\end{array}$ & $\begin{array}{c}0.087 \\
229 \\
3,179\end{array}$ & $\begin{array}{l}-0.008 \\
226 \\
2,667\end{array}$ & $\begin{array}{c}0.120 \\
226 \\
2,667\end{array}$ & $\begin{array}{c}0.728 \\
151 \\
920\end{array}$ \\
\hline $\begin{array}{l}\text { Control Mean: LLCs } \\
N, \text { LLCs } \\
N \text {, Firm-Years LLCs }\end{array}$ & $\begin{array}{c}4.366 \\
12,639 \\
146,289\end{array}$ & $\begin{array}{c}4.434 \\
12,639 \\
146,289\end{array}$ & $\begin{array}{c}0.049 \\
12,639 \\
146,289\end{array}$ & $\begin{array}{c}-0.064 \\
12,639 \\
146,289\end{array}$ & $\begin{array}{c}-0.057 \\
12,047 \\
116,932\end{array}$ & $\begin{array}{c}-0.032 \\
12,047 \\
116,932\end{array}$ & $\begin{array}{c}0.757 \\
3,694 \\
18,008\end{array}$ \\
\hline
\end{tabular}

Note: The table reports the effect of shared governance on wages. Panel A reports the effect of shared governance, $\hat{\gamma}^{\text {Diff, }}$, in simple difference specifications (1) comparing stock corporations incorporated in a two-year window before vs. after the August 10, 1994 cutoff date. Panel B reports difference-in-differences results, $\hat{\gamma}^{\mathrm{DiD}}$ in Equation (2), additionally drawing on LLCs (a legal form unaffected by the 1994 reform) as a control group. Panel $C$ reports estimates $\hat{\gamma}^{\mathrm{RD}}$ from the RD specifications in Equation (3). We use 2-digit NACE designations to create industry-year fixed effects. All outcomes, with the exception of the indicator variable in Column (3), are winsorized at the $1 \%$ level by year. The control means refer to observations of firms incorporated on or after August 10, 1994. Standard errors are clustered at the firm level and reported in parentheses. Stars denote statistical significance: ${ }^{*} p<0.10,{ }^{* *} p<0.05,{ }^{* * *} p<0.01$. 
Table 2: Effect of Shared Governance on Labor Productivity and Capital Intensity

\begin{tabular}{|c|c|c|c|c|c|c|c|c|c|c|}
\hline & $\begin{array}{l}\text { Log VA } \\
\text { per Emp } \\
\quad(1)\end{array}$ & $\begin{array}{l}\text { Log Value } \\
\text { Added } \\
\text { (2) }\end{array}$ & $\begin{array}{l}\text { Log Revenue } \\
\text { per Emp. } \\
\text { (3) }\end{array}$ & $\begin{array}{c}\text { Log } \\
\text { Revenue } \\
(4)\end{array}$ & $\begin{array}{l}\text { Log Emp } \\
(\mathrm{BvD}) \\
(5)\end{array}$ & $\begin{array}{l}\text { Log Emp } \\
\text { (IAB) } \\
(6)\end{array}$ & $\begin{array}{l}\log \\
\text { Fixed A. } \\
\quad(7)\end{array}$ & $\begin{array}{l}\log \\
\text { Tang. A. } \\
\text { (8) }\end{array}$ & $\begin{array}{l}\text { Log Fixed A. } \\
\text { per Emp } \\
(9)\end{array}$ & $\begin{array}{l}\text { Log Tang. A. } \\
\text { per Emp. } \\
\quad(10)\end{array}$ \\
\hline \multicolumn{11}{|c|}{ Panel A: Difference Design (Stock Corporations) } \\
\hline Year FE & $\begin{array}{c}0.075 \\
(0.118)\end{array}$ & $\begin{array}{c}0.022 \\
(0.221)\end{array}$ & $\begin{array}{c}0.058 \\
(0.154)\end{array}$ & $\begin{array}{c}0.159 \\
(0.264)\end{array}$ & $\begin{array}{c}0.070 \\
(0.158)\end{array}$ & $\begin{array}{c}0.045 \\
(0.144)\end{array}$ & $\begin{array}{c}0.500 \\
(0.322)\end{array}$ & $\begin{array}{c}0.323 \\
(0.283)\end{array}$ & $\begin{array}{c}0.478^{*} \\
(0.260)\end{array}$ & $\begin{array}{c}0.273 \\
(0.209)\end{array}$ \\
\hline Industry-Year FE & $\begin{array}{c}0.022 \\
(0.114)\end{array}$ & $\begin{array}{c}-0.233 \\
(0.229)\end{array}$ & $\begin{array}{c}0.137 \\
(0.140)\end{array}$ & $\begin{array}{c}0.212 \\
(0.266)\end{array}$ & $\begin{array}{c}0.005 \\
(0.158)\end{array}$ & $\begin{array}{c}0.056 \\
(0.153)\end{array}$ & $\begin{array}{c}0.546 \\
(0.352)\end{array}$ & $\begin{array}{c}0.490 \\
(0.299)\end{array}$ & $\begin{array}{l}0.587^{* *} \\
(0.273)\end{array}$ & $\begin{array}{l}0.486^{* *} \\
(0.224)\end{array}$ \\
\hline \multicolumn{11}{|c|}{ Panel B: Difference-in-Differences Design (Stock Corporations + LLC Control Group) } \\
\hline Year FE & $\begin{array}{c}0.074 \\
(0.119)\end{array}$ & $\begin{array}{c}0.015 \\
(0.224)\end{array}$ & $\begin{array}{c}0.055 \\
(0.154)\end{array}$ & $\begin{array}{c}0.152 \\
(0.265)\end{array}$ & $\begin{array}{c}0.050 \\
(0.160)\end{array}$ & $\begin{array}{c}0.065 \\
(0.144)\end{array}$ & $\begin{array}{c}0.431 \\
(0.323)\end{array}$ & $\begin{array}{c}0.270 \\
(0.284)\end{array}$ & $\begin{array}{c}0.443^{*} \\
(0.261)\end{array}$ & $\begin{array}{c}0.253 \\
(0.211)\end{array}$ \\
\hline Industry-Year FE & $\begin{array}{c}0.055 \\
(0.113)\end{array}$ & $\begin{array}{c}-0.033 \\
(0.226)\end{array}$ & $\begin{array}{c}0.177 \\
(0.141)\end{array}$ & $\begin{array}{c}0.296 \\
(0.260)\end{array}$ & $\begin{array}{c}0.092 \\
(0.154)\end{array}$ & $\begin{array}{c}0.046 \\
(0.136)\end{array}$ & $\begin{array}{c}0.514 \\
(0.317)\end{array}$ & $\begin{array}{c}0.394 \\
(0.264)\end{array}$ & $\begin{array}{l}0.492^{* *} \\
(0.250)\end{array}$ & $\begin{array}{c}0.338^{*} \\
(0.196)\end{array}$ \\
\hline $\begin{array}{l}\text { Control Mean: Stock Cs } \\
N \text {, Stock Cs } \\
N \text {, Firm-Years Stock Cs }\end{array}$ & $\begin{array}{c}11.367 \\
146 \\
894\end{array}$ & $\begin{array}{c}16.062 \\
152 \\
923\end{array}$ & $\begin{array}{c}12.262 \\
171 \\
892\end{array}$ & $\begin{array}{c}16.526 \\
178 \\
982\end{array}$ & $\begin{array}{c}4.174 \\
212 \\
1,367\end{array}$ & $\begin{array}{c}3.880 \\
229 \\
3,179\end{array}$ & $\begin{array}{c}13.966 \\
217 \\
1,548\end{array}$ & $\begin{array}{c}12.962 \\
217 \\
1,535\end{array}$ & $\begin{array}{c}9.962 \\
212 \\
1,359\end{array}$ & $\begin{array}{c}8.935 \\
211 \\
1,350\end{array}$ \\
\hline $\begin{array}{l}\text { Control Mean: LLCs } \\
N \text {, LLCs } \\
N \text {, Firm-Years LLCs }\end{array}$ & $\begin{array}{c}11.074 \\
3,524 \\
16,783\end{array}$ & $\begin{array}{c}15.215 \\
3,715 \\
18,110\end{array}$ & $\begin{array}{c}11.976 \\
8,776 \\
35,983\end{array}$ & $\begin{array}{c}15.264 \\
9,242 \\
43,434\end{array}$ & $\begin{array}{c}3.318 \\
11,096 \\
57,006\end{array}$ & $\begin{array}{c}3.255 \\
12,639 \\
146,289\end{array}$ & $\begin{array}{l}12.424 \\
11,491 \\
72,988\end{array}$ & $\begin{array}{l}12.132 \\
11,407 \\
72,177\end{array}$ & $\begin{array}{c}9.243 \\
11,000 \\
56,265\end{array}$ & $\begin{array}{c}8.935 \\
10,916 \\
55,724\end{array}$ \\
\hline
\end{tabular}

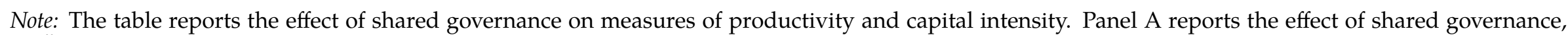

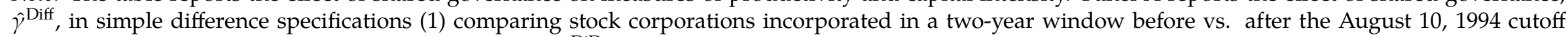

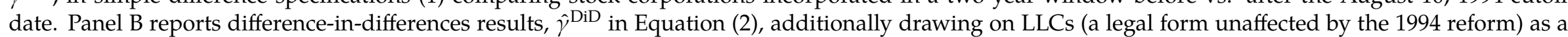

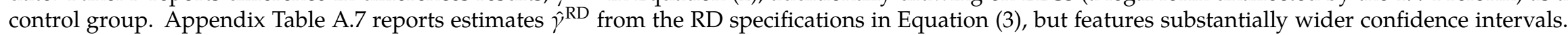

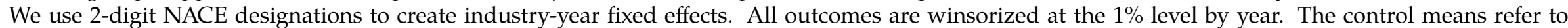

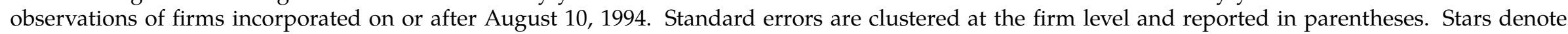
statistical significance: ${ }^{*} p<0.10,{ }^{* *} p<0.05,{ }^{* * *} p<0.01$. 


\section{Figures}

\section{Figure 1: Corporate Governance and Worker Representation on Supervisory Board}

(a) One-Third Worker Representation

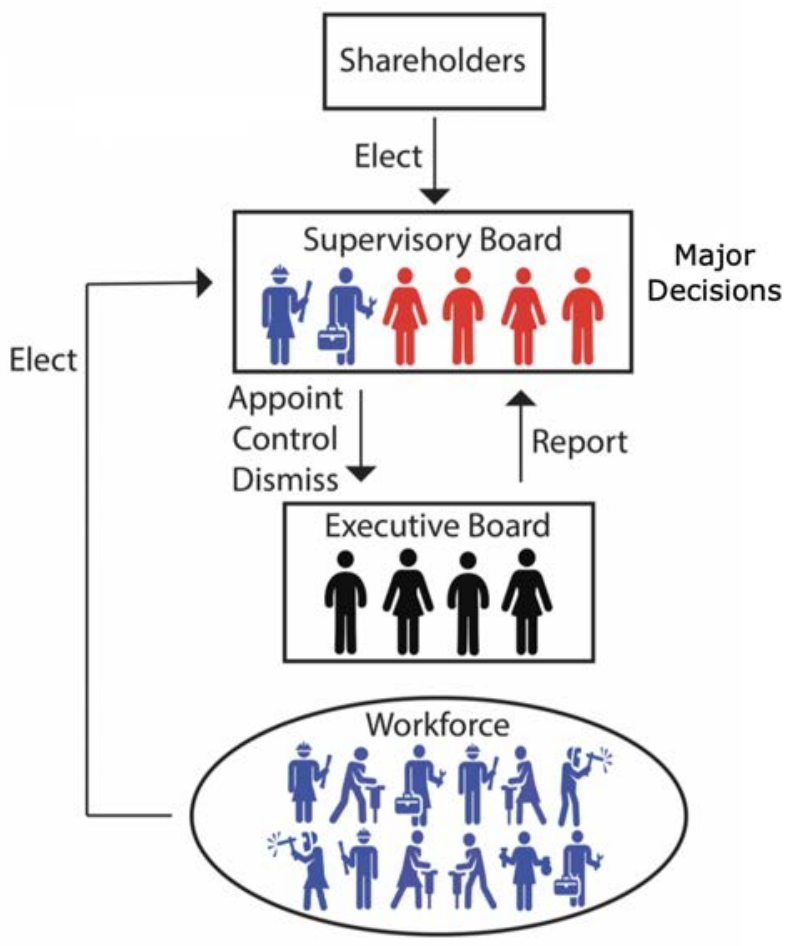

(b) No Worker Representation

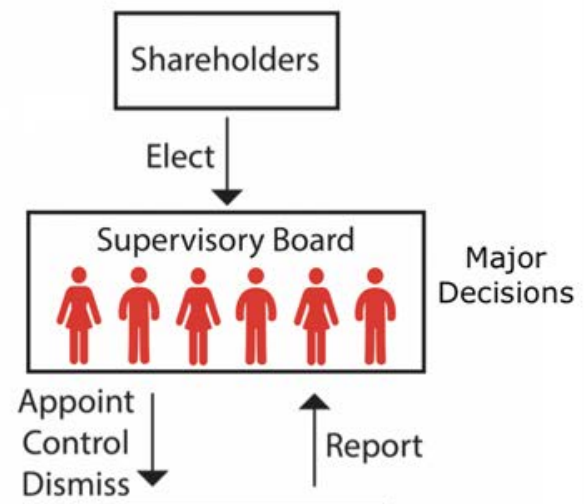

Note: The figure illustrates the supervisory board composition and election in German corporations with and without worker-elected supervisory board directors. Panel (a) illustrates the stylized corporate governance structure with one-third worker representation (here depicted as the blue supervisory board members). Panel (b) shows the stylized corporate governance structure with no worker representation. Our paper studies variation in whether workers elect a third of the supervisory board members. 
Figure 2: Overview of Reform and Research Design

(a) Worker Representation by Legal Form and Incorporation Date

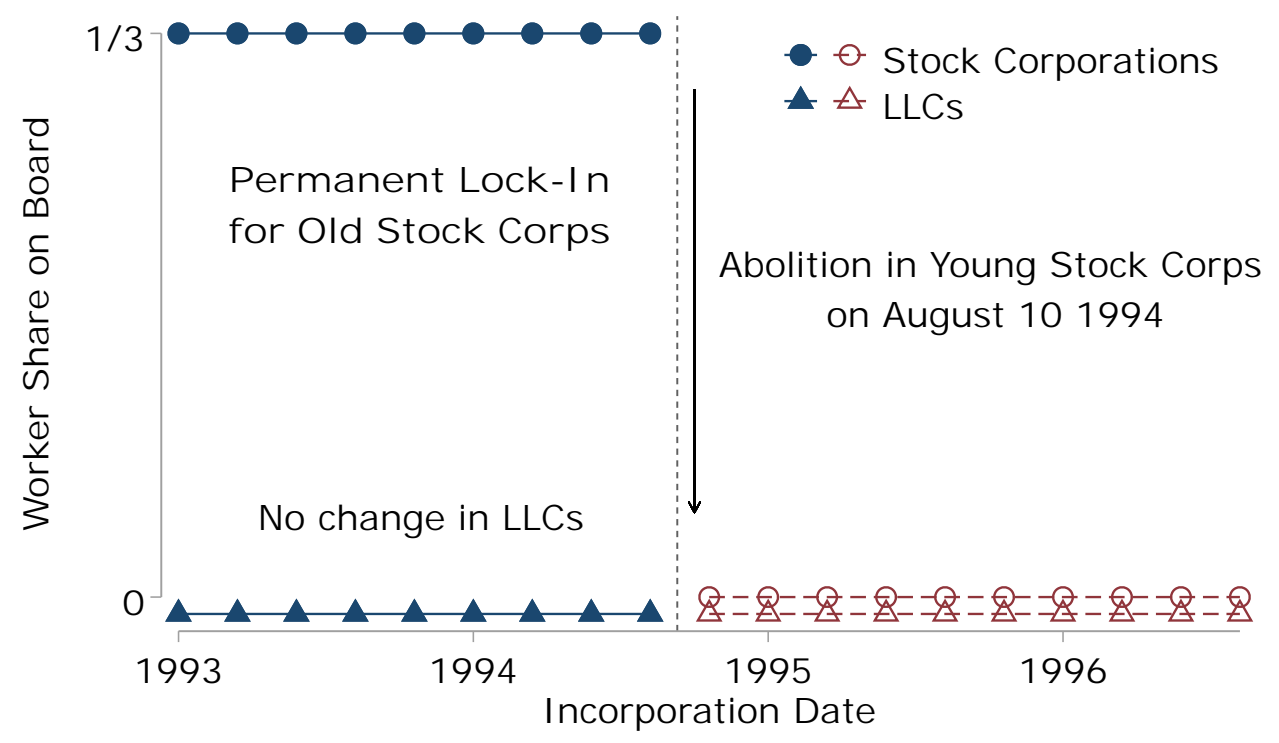

(b) Empirical Share of Worker Board Seats in Listed Stock Corporations

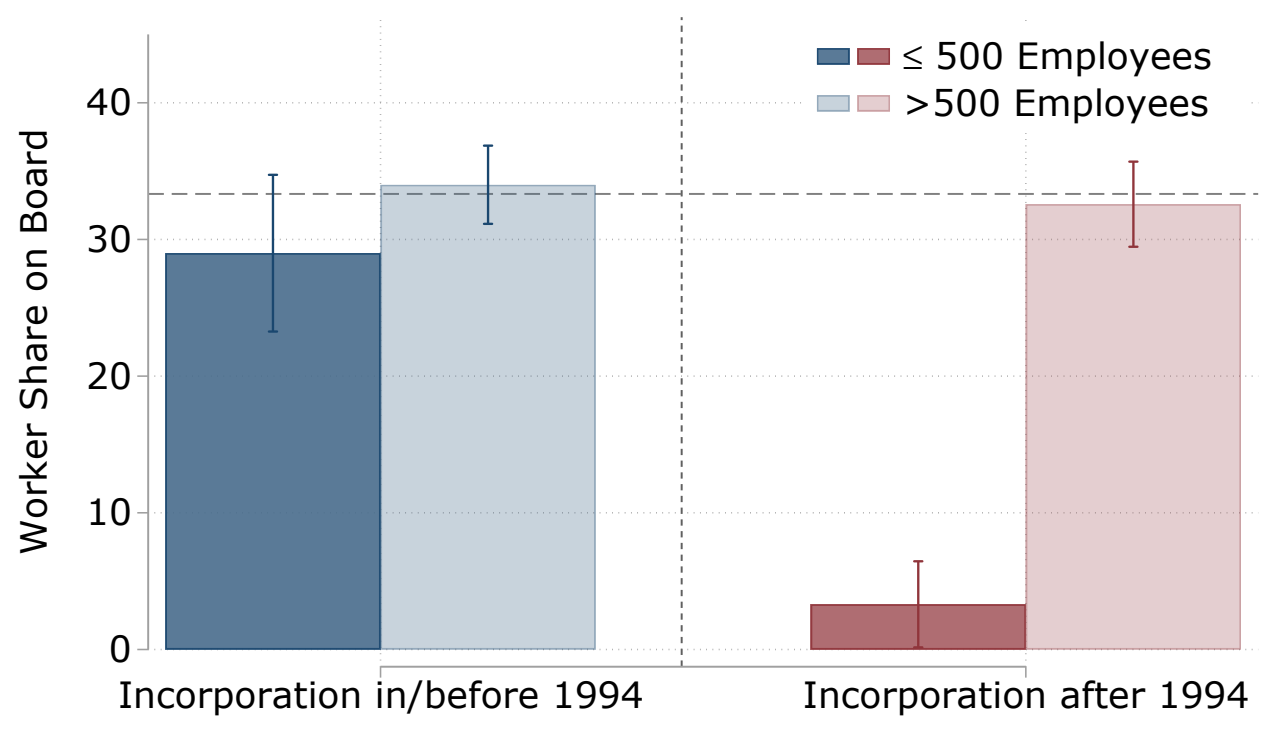

Note: Panel (a) illustrates board codetermination rules as a function of incorporation date and legal form among firms with at most 500 employees. Stock corporations incorporated before August 10, 1994 face a mandate to have one-third worker representatives on the supervisory board. Stock corporations incorporated on or after August 10, 1994 have no worker representatives on the supervisory board. LLCs, which we use as control group in the DiD specifications, have no worker representation on the board. Regardless of incorporation date and legal form, firms with 501 to 2,000 workers have one-third representation, firms with more than 2,000 employees have quasi-parity representation. See Section 2.1 for more information. Panel (b) shows the empirical share of worker seats in listed stock corporations founded between 1989 and 1999 based on the Hoppenstedt Aktienführer, by size and incorporation date. 
Figure 3: Validation of Design: Incorporation, Selection, and Survival

(a) Frequency of Incorporation and McCrary Test

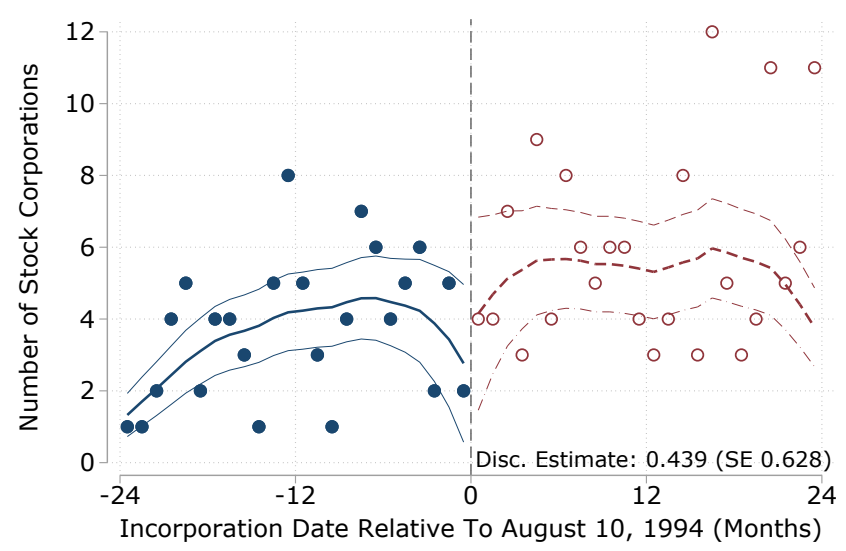

(b) Selection Into Stock Corporation Status

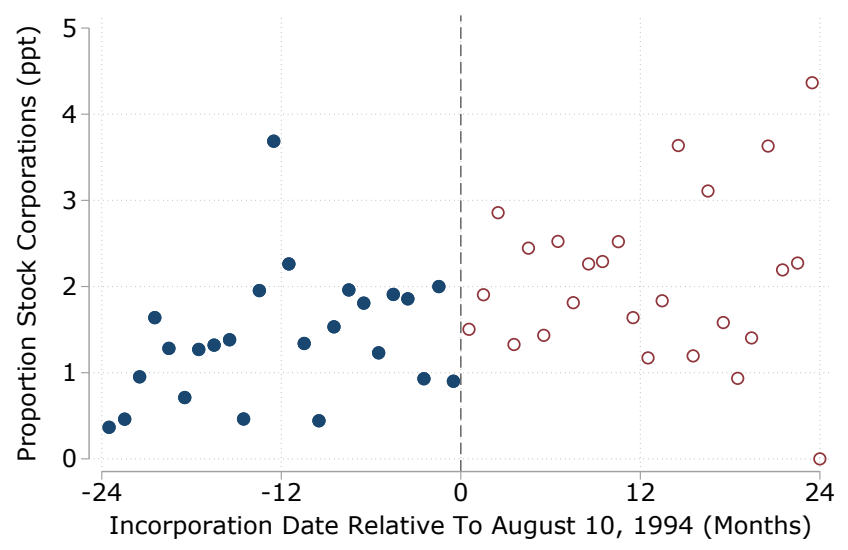

(c) Balance of Industry Composition

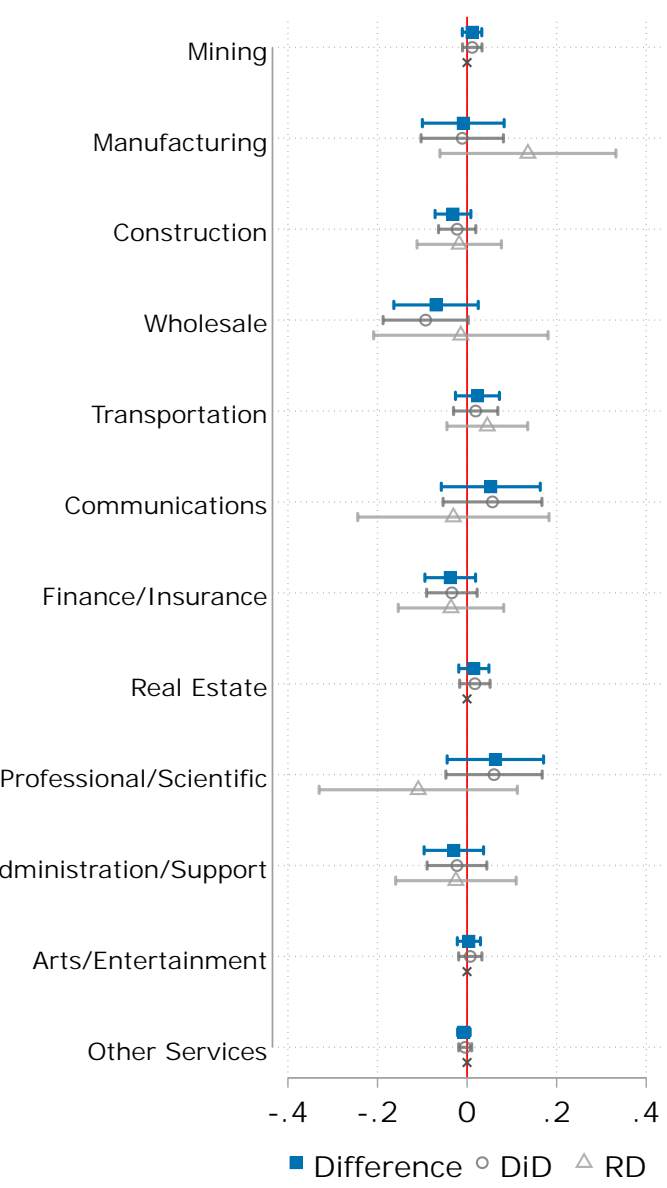

(d) Survival Probability by Group

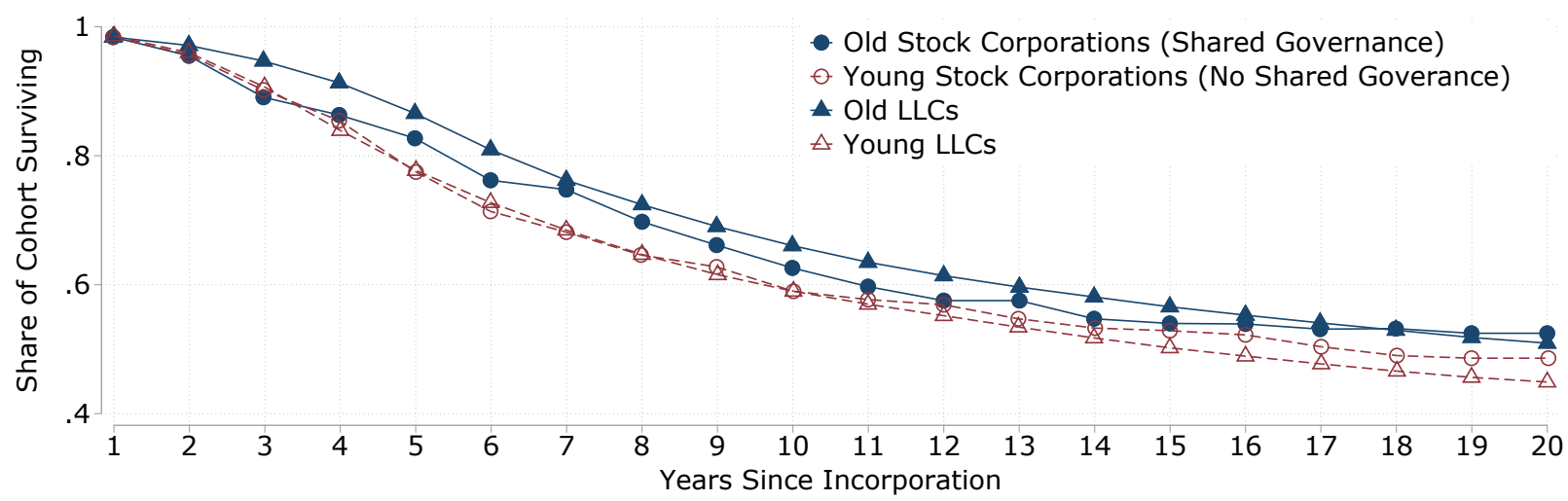

Note: Panel (a) plots the frequency of the incorporation of stock corporations around the August 10, 1994 cutoff date, after which the shared governance mandate was relaxed. It reports the result of the McCrary (2008) test for a jump in the density at the threshold. Panel (b) visualizes the selection into stock corporation status as the share of a sample of all incorporations (stock corporations and LLCs) by incorporation date. Appendix Table A.1 reports corresponding regression results. Panel (c) plots the simple difference $\left(\hat{\gamma}^{\text {Diff }}\right)$, difference-in-differences $\left(\hat{\gamma}^{\mathrm{DiD}}\right)$ and regression discontinuity $\left(\hat{\gamma}^{\mathrm{RD}}\right)$ coefficients with $95 \%$ confidence intervals corresponding to, respectively, Equations (1), 2), and (3) with an indicator for industry type (NACE Rev. 2 Classification 1) as the outcome variable. Some industries are excluded due to insufficient observations among stock corporations.F-tests of joint significance show no statistically significant compositional changes in any of the three specifications with $p$-values of $p=0.384, p=0.396$ and $p=0.828$, respectively. Due to insufficient observations, some industries are dropped in the RD design (denoted by a gray $\times$ ). Appendix Table A.2 reports the corresponding regression results in detail. Panels (a) through (c) of this figure are based on the Orbis-ADIAB data; we plot versions of Panels (a) and (c) in Appendix Figure A.1 using the Mannheim Enterprise Panel (MUP) data. Panel (d) is based on MUP data and shows survival probabilities of firms incorporated within a two-year window of August 10, 1994 separately for firms incorporated before or after the cutoff date, and for stock corporations and LLCs. 
Figure 4: Effects on Mean Log Wages

(a) Over Time, by Group

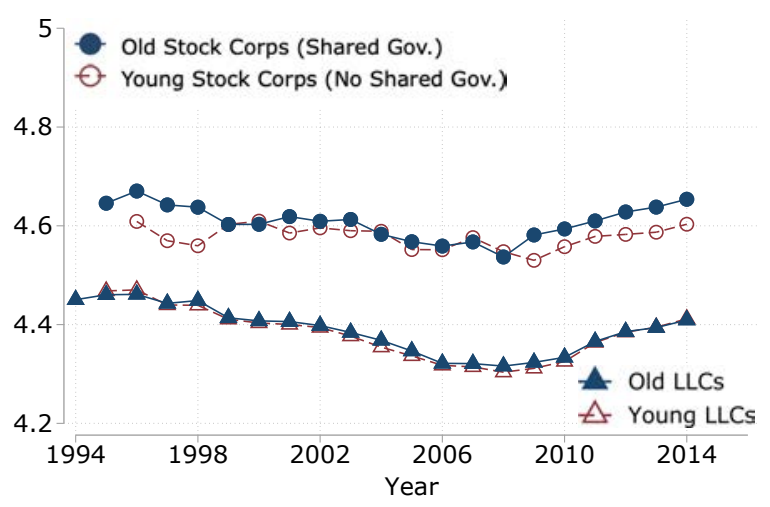

(c) Differences (Old - Young Stock Corps), By Bandwidth Around Reform Date

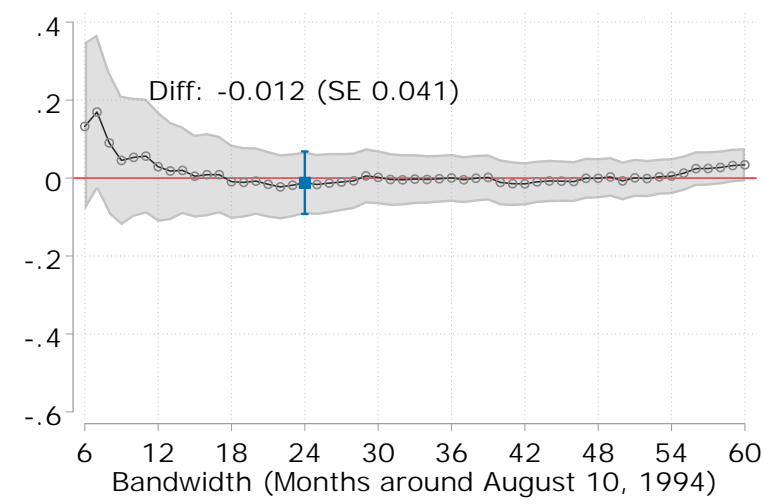

(e) RD Estimates Among Stock Corporations, By Bandwidth Around Reform Date

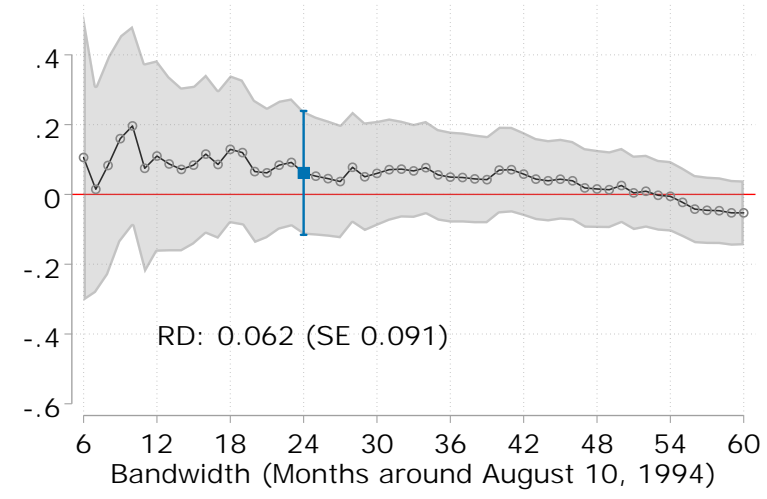

(b) By Incorporation Date and Legal Form

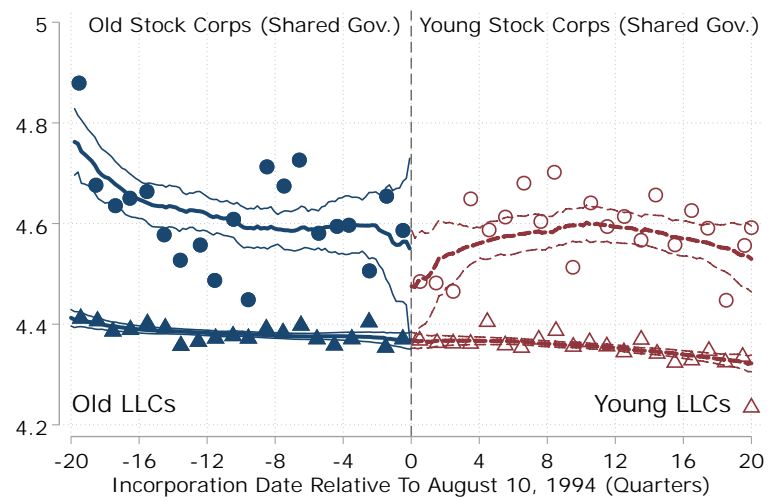

(d) $\mathrm{DiD}$ (w/ LLCs as Additional Control Group), By Bandwidth Around Reform Date

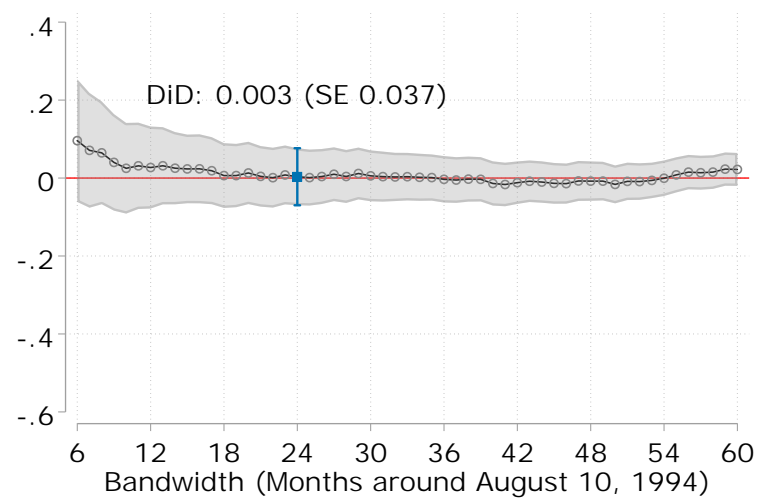

(f) RD Donut Hole Estimate, Excluding Months Around Reform Date

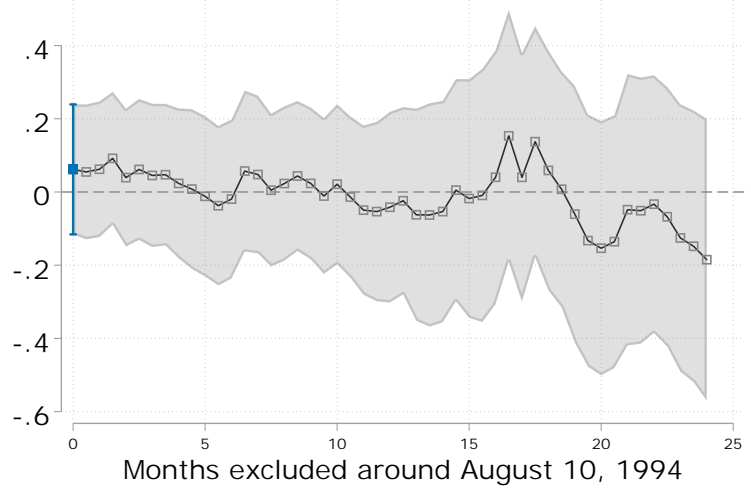

Note: The figure displays the effects of shared governance on firm-level mean worker-level log wages. Panel (a) presents the time series of old (incorporated up to two years before the cutoff) and young (incorporated up to two years after the cutoff) firms, of stock corporations and LLCs, averaged by firm group and year. Panel (b) is a binned scatter plot by quarter of incorporation date around the reform cutoff with a five-year bandwidth. It also plots results of a local linear regression with a uniform kernel and a two-year bandwidth, using day-specific incorporation date as the running variable. Panels (c), (d), and (e) plot the coefficients varying the bandwidths for, respectively, the simple difference, difference-in-differences, and regression discontinuity specifications with industry-year fixed effects and standard errors clustered at the firm level. Panel (f) reports regression discontinuity estimates for a donut hole specification with a two-year bandwidth, industry-year fixed effects, and standard errors clustered at the firm level. Here we drop observations in a radius, indicated on the x-axis, around the reform cutoff and extend the overall two-year bandwidth correspondingly. We report the corresponding main estimates, denoted in Panels (c) through (f) by the highlighted blue square and blue $95 \%$ confidence interval, in Table[1]Column (1). 
Figure 5: Effects on AKM Pay Premia

(a) Over Time, By Group

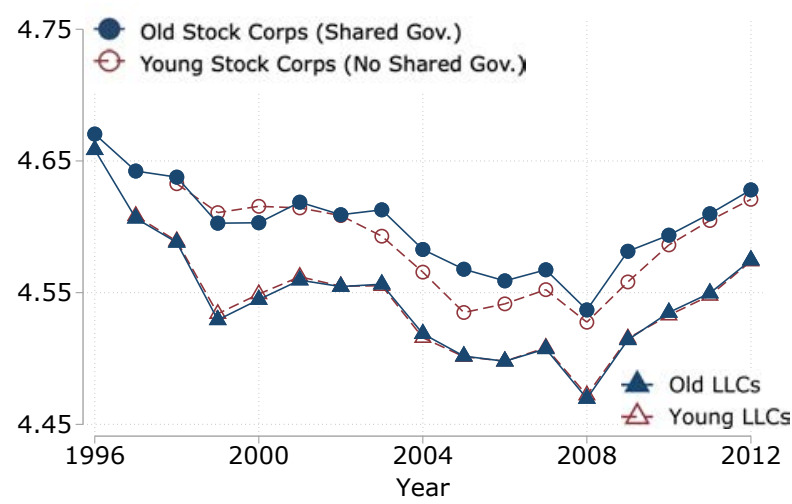

(c) Differences (Old - Young Stock Corps), By Bandwidth Around Reform Date

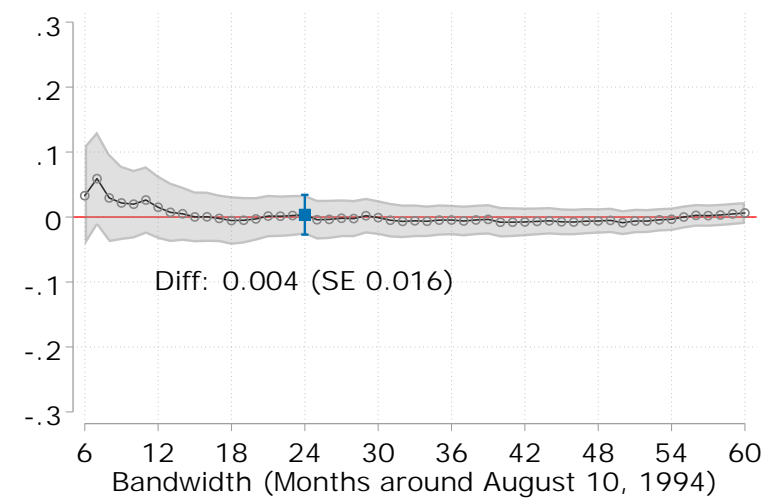

(e) RD Estimates Among Stock Corporations, By Bandwidth Around Reform Date

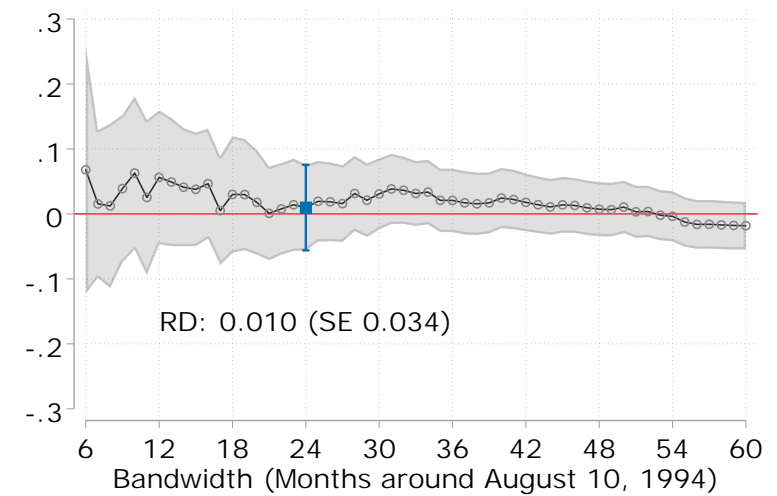

(b) By Incorporation Date and Legal Form

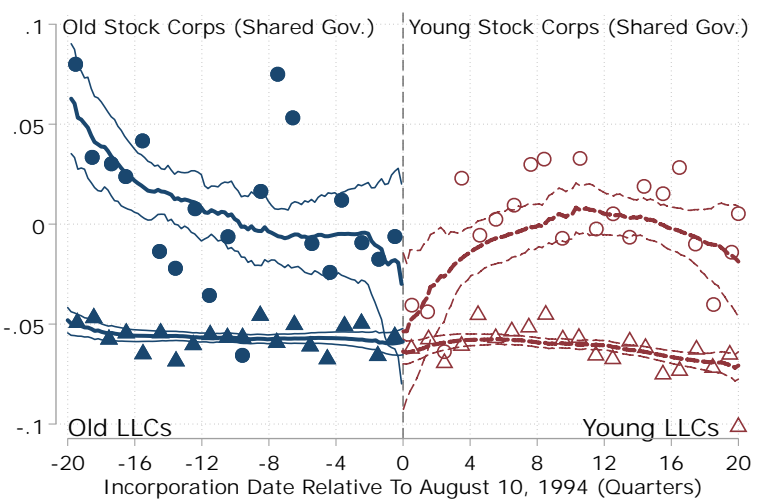

(d) DiD (w / LLCs as Additional Control Group), By Bandwidth Around Reform Date

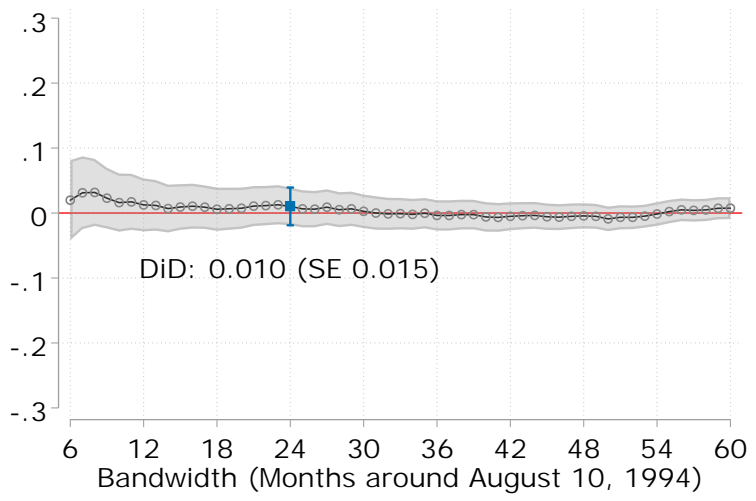

(f) RD Donut Hole Estimate, Excluding Months Around Reform Date

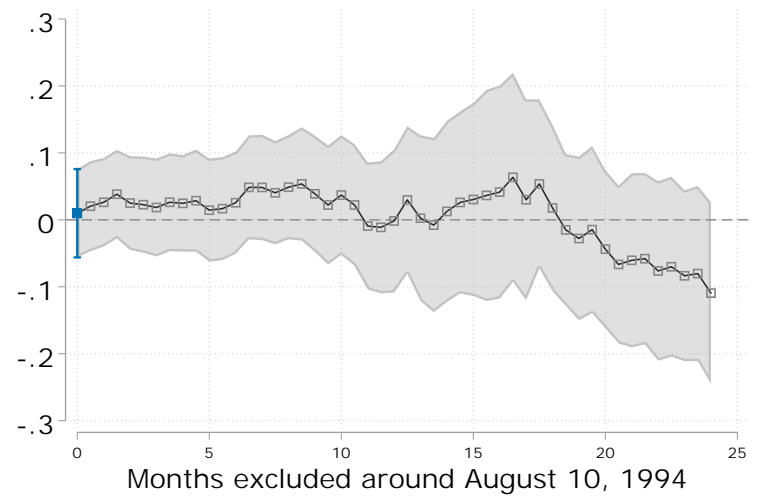

Note: The figure displays the effects of shared governance on AKM firm effects. Panel (a) presents the time series of old (incorporated up to two years before the cutoff) and young (incorporated up to two years after the cutoff) firms, of stock corporations and LLCs, averaged by firm group and year. Panel (b) is a binned scatter plot by quarter of incorporation date around the reform cutoff with a five-year bandwidth. It also plots results of a local linear regression with a uniform kernel and a two-year bandwidth, using day-specific incorporation date as the running variable. Each calendar year indicates the mid-point of a five-year estimation window of the AKM effects. (Since the levels of the AKM specifications are not comparable across years, we normalize the AKM pay premia among older stock corporations to correspond to the average log wage in this firm group within each year and adjust the premia in the other groups accordingly.) Panels (c), (d), and (e) plot the coefficients and 95\% confidence intervals varying the bandwidths for, respectively, the simple difference, difference-in-differences, and regression discontinuity specification with industry-year fixed effects and standard errors clustered at the firm level. Panel (f) reports regression discontinuity estimates for a donut hole specification with a two-year bandwidth, industry-year fixed effects, and standard errors clustered at the firm level. Here we drop observations in a radius, indicated on the $\mathrm{x}$-axis, around the reform cutoff and extend the overall two-year bandwidth correspondingly. We report the corresponding main estimates, denoted in Panels (c) through (f) by the highlighted blue square and blue 95\% confidence interval, in Table 1 Column (2). 
Figure 6: Effects on the Wage Distribution

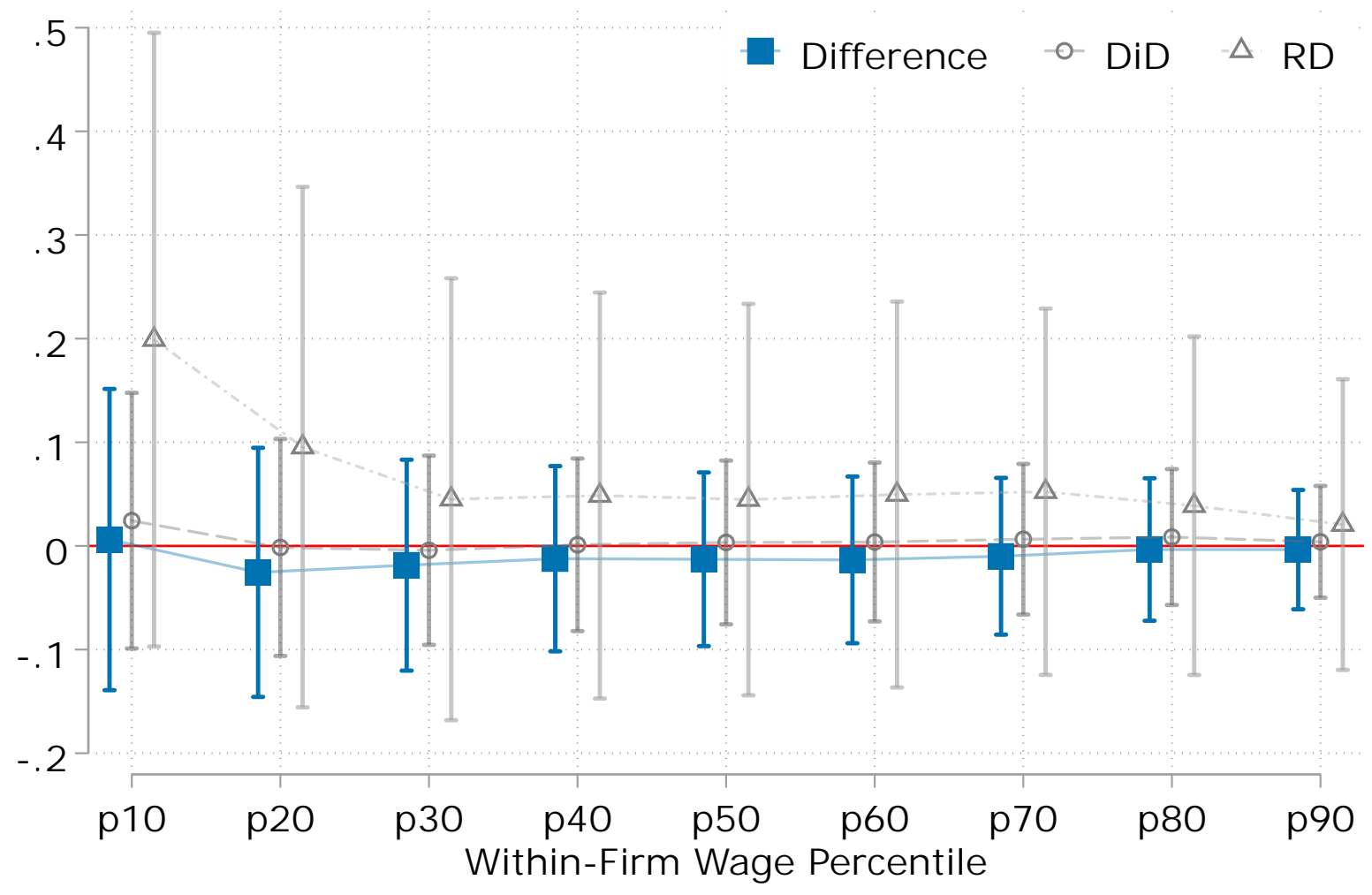

Note: The figure displays the effect of shared governance on the within-firm wage distribution. Specifically we study as outcome variables the deciles of the within-firm log wage distribution in a given year. Blue squares denote the effect of shared governance, $\hat{\gamma}^{\text {Diff }}$, in Equation (1) comparing stock corporations incorporated in a two-year window before and after the August 10, 1994 cutoff date. Grey hollow circles denote difference-indifferences results, $\hat{\gamma}^{\mathrm{DiD}}$ in Equation (2), additionally drawing on LLCs (a legal form unaffected by the 1994 reform) as a control group. Grey hollow triangles denote results for RD estimates $\hat{\gamma}^{\mathrm{RD}}$ in Equation (3). We use 2-digit NACE designations to create industry-year fixed effects. The vertical lines denote $95 \%$ confidence intervals with standard errors clustered at the firm level. Appendix Table A.3 reports the full regression results. 
Figure 7: Effects on Labor Productivity and Capital Intensity

(a) Log Value Added per Worker

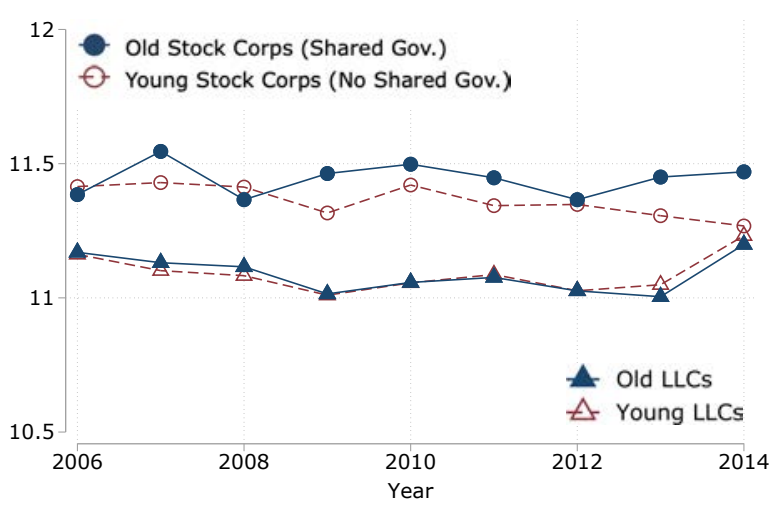

(c) Log Fixed Assets

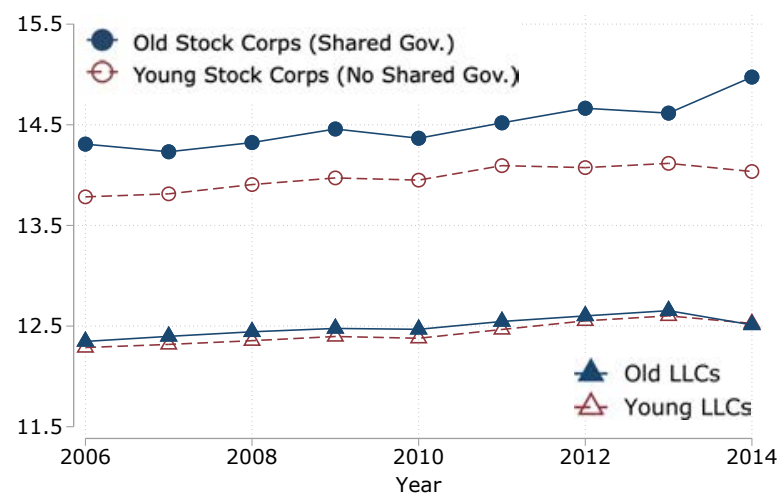

(e) Log Fixed Assets per Worker

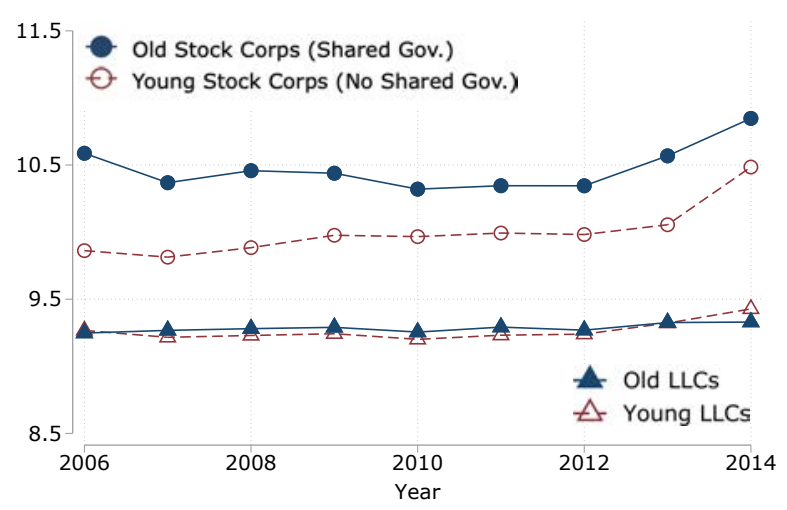

(b) Differences (Old - Young Stock Corps)

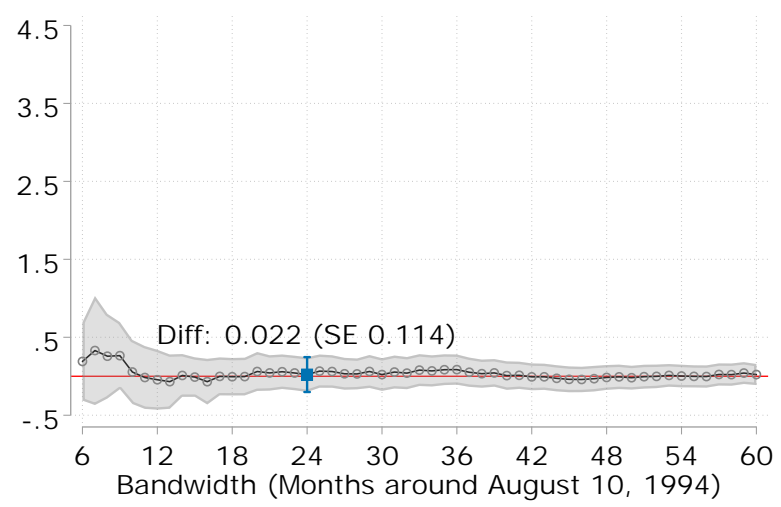

(d) Differences (Old - Young Stock Corps)

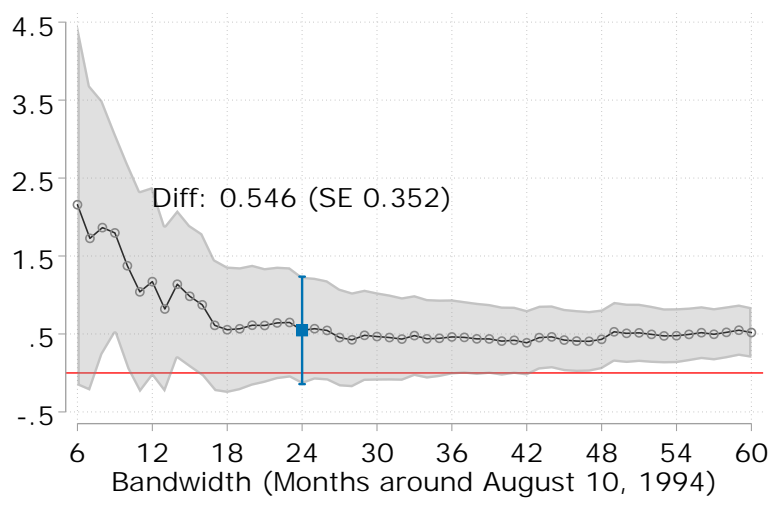

(f) Differences (Old - Young Stock Corps)

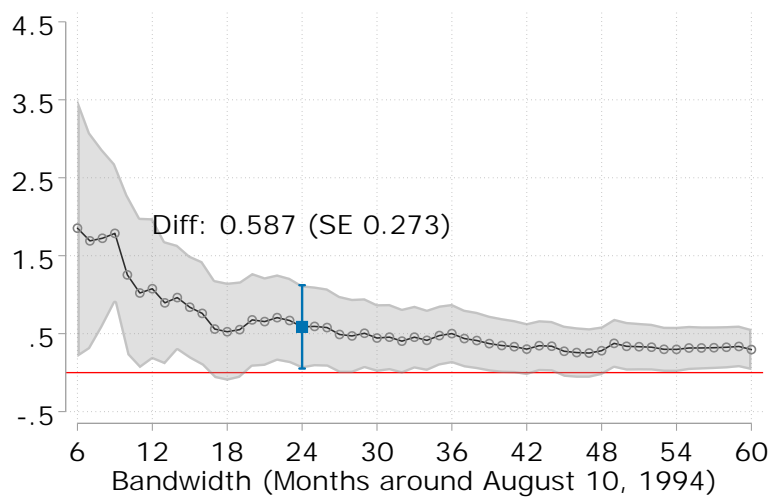

Note: The figure displays the effects of shared governance on firm-level labor productivity and capital. The left column presents the time series of old (incorporated up to two years before the cutoff) and young (incorporated up to two years after the cutoff) firms, of stock corporations and LLCs, averaged by firm group and year. The right column plots coefficients and $95 \%$ confidence intervals varying the bandwidth for simple difference specifications with industry-year effects and standard errors clustered at the firm level. We report the corresponding main estimates, denoted in Panels (b), (d), and (e) by the highlighted blue square and blue 95\% confidence interval, in Table 2 Columns (1), (7), and (9). For each outcome, Appendix Figure A.3 reports additional results, namely scatter plots by quarter of incorporation along with RD estimates, and bandwidth plots of DiD specifications with industry-year fixed effects. 
Figure 8: Rent Sharing in Stock Corporations with and without Shared Governance: Firms' Pay Premia (AKM Firm Fixed Effects) and Value Added per Worker

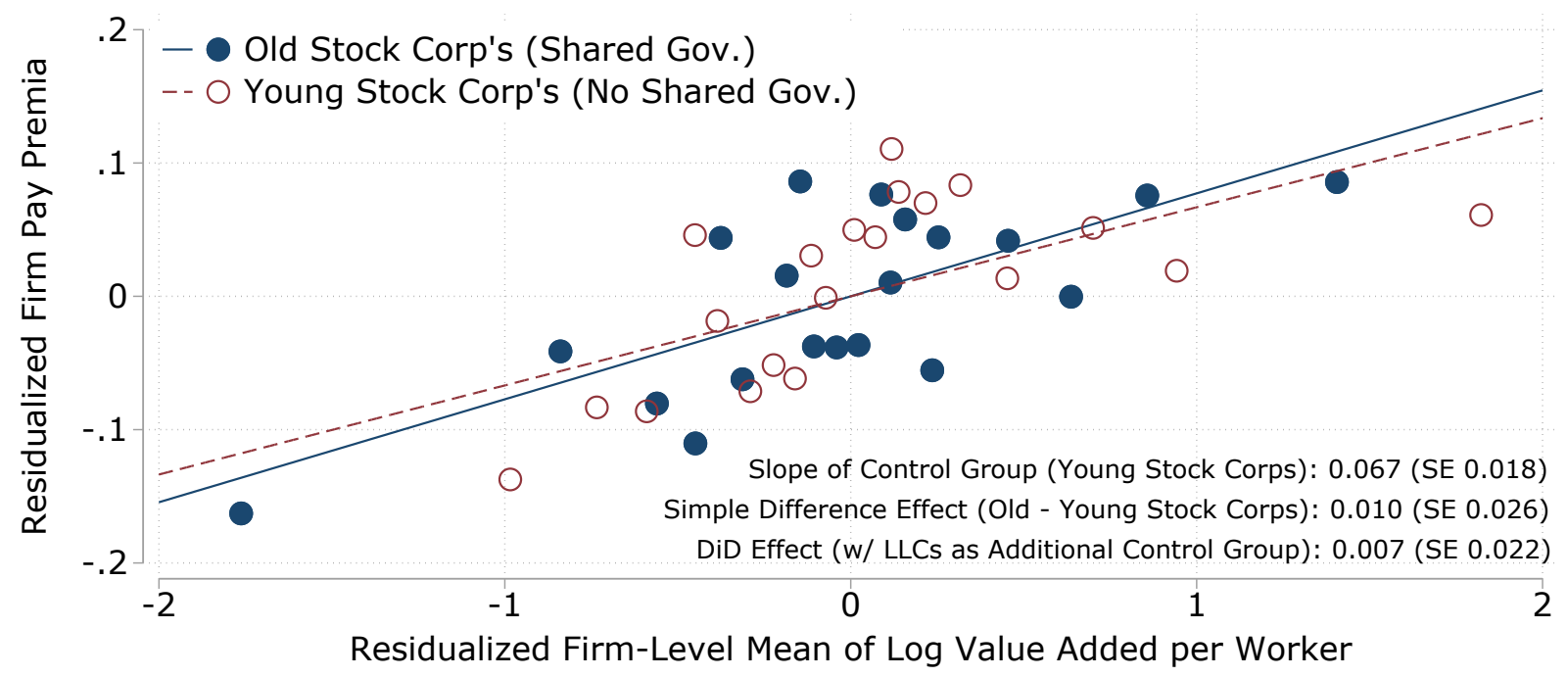

Note: This figure presents a binned scatter plot of firm's average pay premia (AKM firm fixed effects) plotted against average log value added per worker in the 2006-14 sample of the Orbis-ADIAB data. The AKM firm fixed effects are estimated in a five-year rolling window and then averaged by firm. Both variables are residualized by industry (2-digit NACE) fixed effects. The figure draws on our analysis sample of stock corporations incorporated two years around the reform date. It separately plots the observations for older firms, i.e. with shared governance, in solid navy circles and a solid estimated linear regression line, and for younger firms, i.e. without shared governance, in hollow red circles and a dashed regression line. We report the slope of young stock corporations (the control group) in the bottom right along with standard errors. We also report the estimates of the slope from the simple difference and difference-in-differences specifications (with LLCs as a second control group) in the lower right-hand corner. Appendix Figure A.4 displays the pooled rent sharing elasticity including both stock corporations and LLCs. 
Figure 9: Heterogeneity Analysis: Wage Effect of Shared Governance in Subsamples of Firms

(a) Mean Log Wages

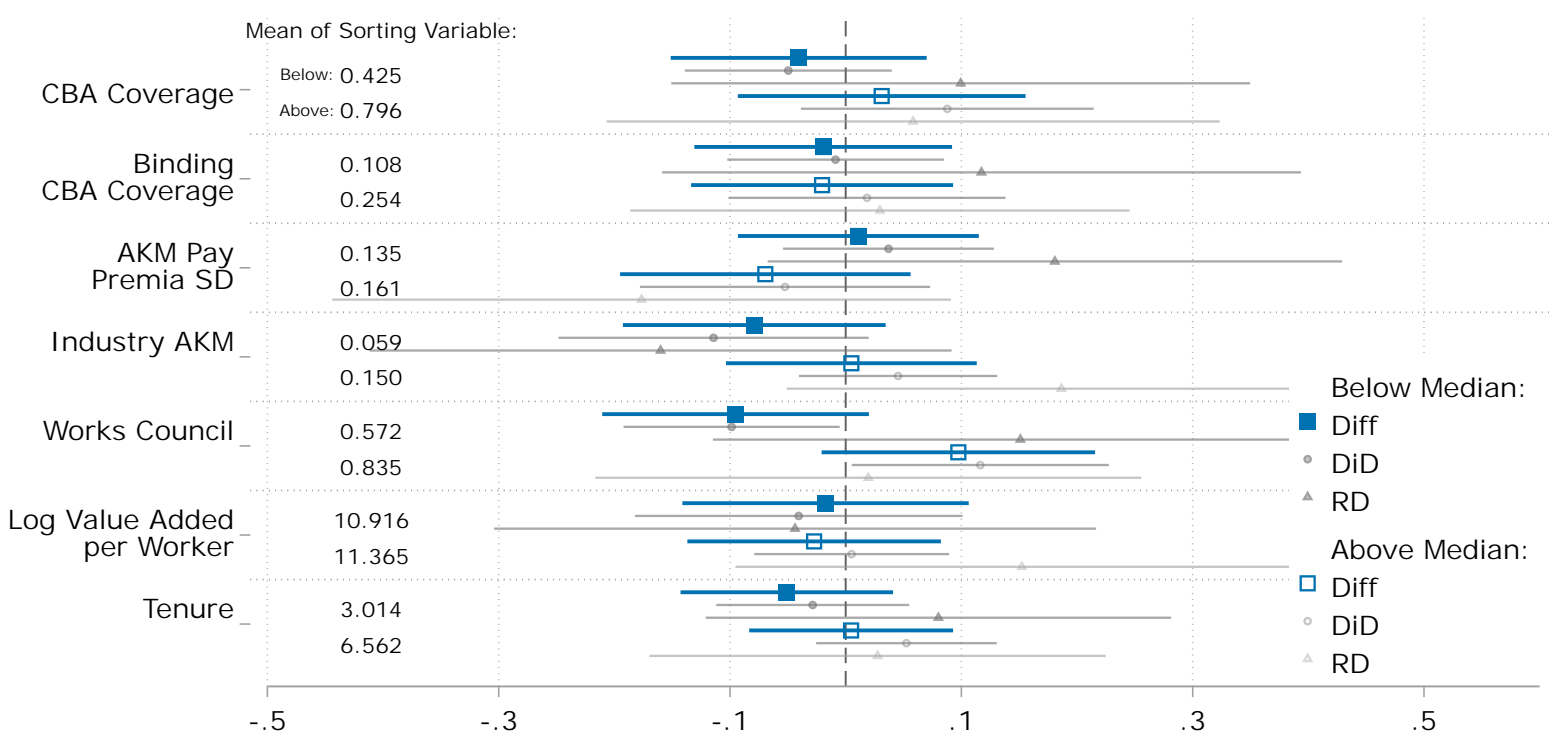

(b) AKM Pay Premia

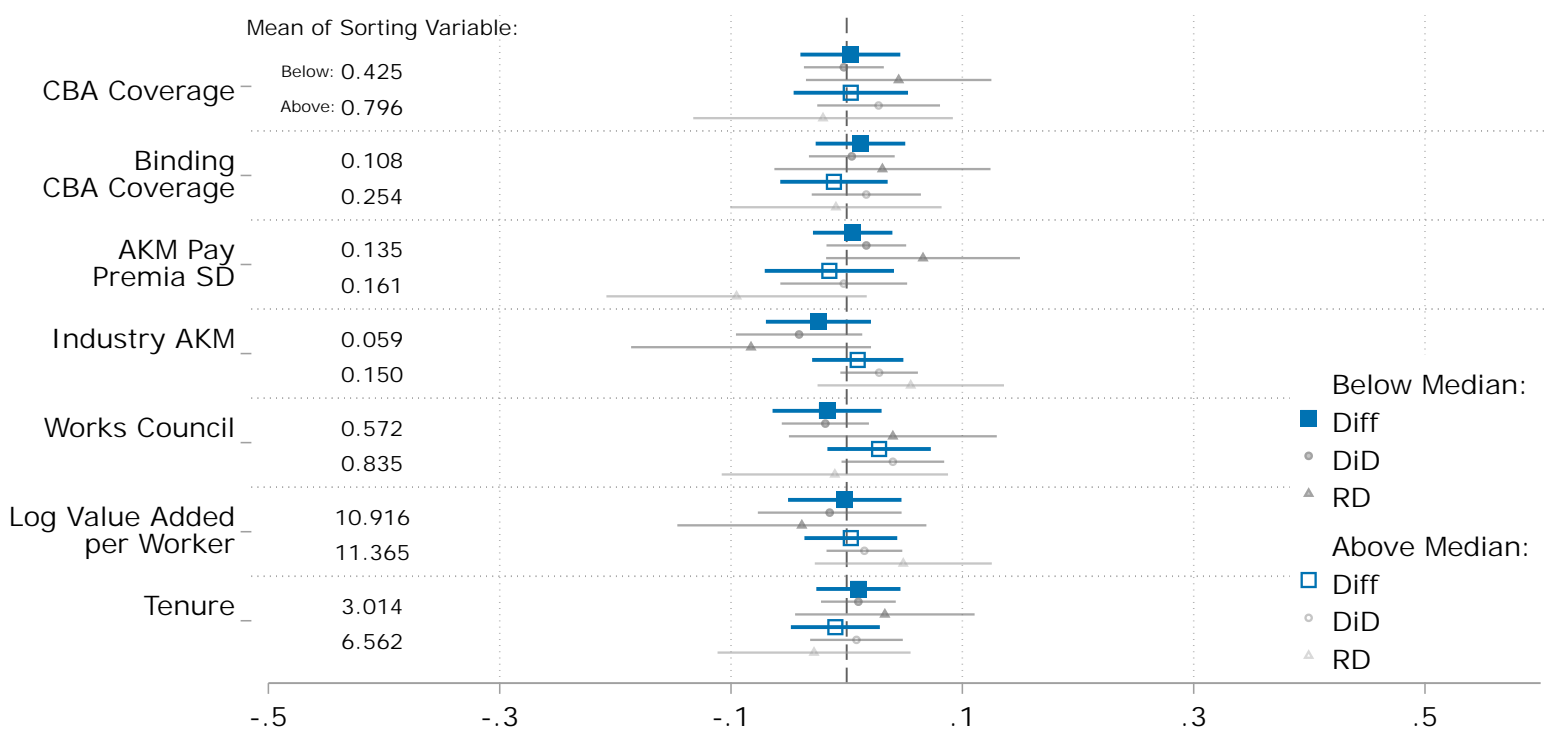

Note: The figure reports heterogeneity in the effect of shared governance on mean log wages (top, Panel (a)) and the AKM firm fixed effect (bottom, Panel (b)). We split the firm sample at the median according the 3-digit NACE industry average of the variables reported on the left-hand side. Blue solid (hollow) squares denote the estimate of the sample with values below (above) the median. We highlight the simple difference specification, and report DiD and RD specifications in gray circles and triangles, respectively. We also print the means of the sorting (heterogeneity) variables on the left column, as shown in the figure. The means are calculated for stock corporations in a two-year bandwidth around the reform. To illustrate, we find a small negative point estimate for the effect on mean log wages among firms in industries with below-median CBA coverage (first solid square), and a small positive point estimate among those with above-median coverage (first hollow square). The CBA and works council variables are based on the IAB Establishment Panel from 2008 onward; the remaining variables based on the Orbis-ADIAB data. All specifications include 2-digit NACE industry-year fixed effects. The horizontal lines indicate $95 \%$ confidence intervals, with standard errors clustered at the firm level. See Section 6.5 for more information; Appendix Table A.11 reports the detailed regression results. 


\section{Online Appendix of: \\ Labor in the Boardroom}

Simon Jäger, Benjamin Schoefer and Jörg Heining

\section{Contents}

\begin{tabular}{|l|l|l|l|l}
\hline A Additional Tables & 53
\end{tabular}

\begin{tabular}{|lr|}
\hline B Additional Figures & 64
\end{tabular}

\begin{tabular}{|lll}
\hline C Theoretical Appendix: Hold-Up, Shared Governance, and Investment & 68
\end{tabular}

C.1 Comparative Statics of Investment to Bargaining Power Parameters $\phi$ and $\iota \quad 69$

C.2 Endogenous Labor . . . . . . . . . . . . . . . . 72

\section{List of Tables}

A.1 Differential Trends for Incorporation of Stock Corporations . . . . . . . . . . 53

A.2 1994 Reform and Industry Composition of Stock Corporations . . . . . . . . 54

A.3 Effects on the Wage Distribution $\ldots \ldots \ldots \ldots \ldots \ldots$

A.4 Placebo: Effect of Shared Governance on Wages (Placebo Reforms in 1996

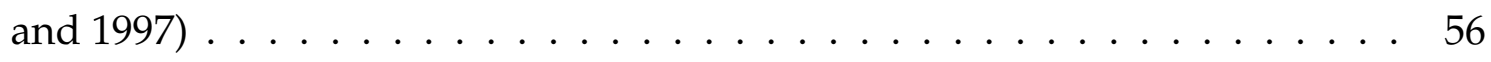

A.5 Effect of Shared Governance on Wages (Non-Missing Fixed Assets) _ . . . . 57

A.6 Effect of Shared Governance on Wages (Non-Missing Value Added per Worker) 58

A.7 Placebo: Effect of Shared Governance on Labor Productivity and Capital Intensity (RD and Placebo Reforms in 1996 and 1997) . . . . . . . . . . . 59

A.8 Effect of Shared Governance on Profitability . . . . . . . . . . . . . . . 60

A.9 Placebo: Effect of Shared Governance on Profitability (Placebo Reforms in 1996 and 1997) . . . . . . . . . . . . . . . . . . . . . . . 61

A.10 Effect of Shared Governance on Skill Structure, Outsourcing, and Tenure

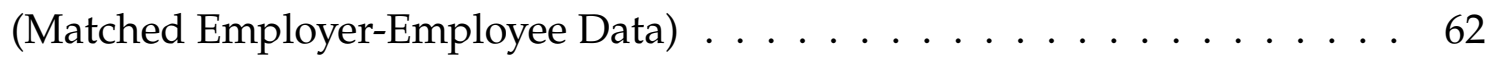

A.11 Heterogeneity of Shared Governance Effects on Wages. . . . . . . . . . . . 63 


\section{List of Figures}

A.1 Frequency of Incorporation and Selection: MUP Data . . . . . . . . . . . . . 64

A.2 Firm Survival and Bankruptcy by Incorporation Date and Corporation Type 65

A.3 Effects on Labor Productivity and Capital Intensity . . . . . . . . . . . 66

A.4 Pooled Rent Sharing : Firms' Pay Premia (AKM Firm Fixed Effects) and Value Added per Worker . . . . . . . . . . . . . . . . . . 67 


\section{A Additional Tables}

Table A.1: Differential Trends for Incorporation of Stock Corporations

\begin{tabular}{lcc}
\hline \hline & \multicolumn{2}{c}{$\mathbb{1}$ (Inc. as Stock Corp.) } \\
\cline { 2 - 3 } & $(1)$ & $(2)$ \\
\hline Incorporation Date & 0.352 & 0.269 \\
& $(0.325)$ & $(0.323)$ \\
& & \\
$\mathbb{1}$ (Pre-Reform) & 0.005 & -0.040 \\
& $(0.470)$ & $(0.465)$ \\
Inc. Date $\times \mathbb{1}$ (Pre-Reform) & 0.046 & 0.139 \\
& $(0.403)$ & $(0.398)$ \\
& & \\
\hline Industry FE & & $\mathrm{X}$ \\
\hline$N$, Stock Cs & 231 & 230 \\
$N$, LLCs & 12,643 & 12,640 \\
& & \\
\hline
\end{tabular}

Note: This table reports estimates of whether the reform had an effect on firms' decision to incorporate as a stock corporation (AG). We test for differential trends before and after the reform by interacting an indicator for whether the firm incorporated pre-reform with a continuous time trend variable (denominated in years) for incorporation date relative to August 10, 1994. Estimates are in percentage points. The sample is restricted to stock corporations ( and limited liability companies (LLCs) with 10 or more employees incorporated within two years of the reform date of August 10, 1994. Column (1) reports the basic specification and Column (2) includes industry fixed effects. The observations are firms rather than firm-years. Standard errors clustered at the firm level are reported in parentheses. Stars denote statistical significance: ${ }^{*} p<0.10,{ }^{* *} p<0.05,{ }^{* * *}$ $p<0.01$. Figure 3 Panel (b) plots the underlying data. 


\section{Table A.2: 1994 Reform and Industry Composition of Stock Corporations}

\begin{tabular}{|c|c|c|c|c|c|c|c|}
\hline NACE Industry Classification & $\mathrm{DiD}$ & Diff & RD & NACE Industry Classification & $\mathrm{DiD}$ & Diff & $\mathrm{RD}$ \\
\hline B: Mining and quarrying & $\begin{array}{c}0.012 \\
(0.011)\end{array}$ & $\begin{array}{c}0.011 \\
(0.011)\end{array}$ & $x$ & K: Financial and insurance activities & $\begin{array}{c}-0.034 \\
(0.029)\end{array}$ & $\begin{array}{c}-0.038 \\
(0.029)\end{array}$ & $\begin{array}{l}-0.036 \\
(0.060)\end{array}$ \\
\hline Control Mean: Post-Reform Stock Cs & 0.0000 & 0.0000 & & Control Mean: Post-Reform Stock Cs & 0.071 & 0.071 & 0.071 \\
\hline Control Mean: Post-Reform LLCs & 0.002 & $\mathrm{n} / \mathrm{a}$ & & Control Mean: Post-Reform LLCs & 0.008 & $\mathrm{n} / \mathrm{a}$ & $\mathrm{n} / \mathrm{a}$ \\
\hline C: Manufacturing & $\begin{array}{l}-0.011 \\
(0.047)\end{array}$ & $\begin{array}{c}-0.009 \\
(0.047)\end{array}$ & $\begin{array}{c}0.136 \\
(0.100)\end{array}$ & L: Real estate activities & $\begin{array}{c}0.017 \\
(0.017)\end{array}$ & $\begin{array}{c}0.015 \\
(0.017)\end{array}$ & $\times$ \\
\hline Control Mean: Post-Reform Stock Cs & 0.142 & 0.142 & 0.142 & Control Mean: Post-Reform Stock Cs & 0.007 & 0.007 & \\
\hline Control Mean: Post-Reform LLCs & 0.213 & $\mathrm{n} / \mathrm{a}$ & $\mathrm{n} / \mathrm{a}$ & Control Mean: Post-Reform LLCs & 0.023 & $\mathrm{n} / \mathrm{a}$ & \\
\hline F: Construction & $\begin{array}{c}-0.022 \\
(0.021)\end{array}$ & $\begin{array}{c}-0.031 \\
(0.020)\end{array}$ & $\begin{array}{l}-0.018 \\
(0.048)\end{array}$ & M: Professional, scientific, and technical activities & $\begin{array}{c}0.060 \\
(0.055)\end{array}$ & $\begin{array}{c}0.063 \\
(0.055)\end{array}$ & $\begin{array}{l}-0.109 \\
(0.113)\end{array}$ \\
\hline Control Mean: Post-Reform Stock Cs & 0.043 & 0.043 & 0.043 & Control Mean: Post-Reform Stock Cs & 0.170 & 0.170 & 0.170 \\
\hline Control Mean: Post-Reform LLCs & 0.151 & $\mathrm{n} / \mathrm{a}$ & $\mathrm{n} / \mathrm{a}$ & Control Mean: Post-Reform LLCs & 0.057 & $\mathrm{n} / \mathrm{a}$ & $\mathrm{n} / \mathrm{a}$ \\
\hline G: Wholesale and retail trade; repair of motor vehicles & $\begin{array}{l}-0.092^{*} \\
(0.048)\end{array}$ & $\begin{array}{c}-0.069 \\
(0.048)\end{array}$ & $\begin{array}{c}-0.014 \\
(0.099)\end{array}$ & $\mathrm{N}$ : Administrative and support service activities & $\begin{array}{l}-0.023 \\
(0.034)\end{array}$ & $\begin{array}{l}-0.030 \\
(0.034)\end{array}$ & $\begin{array}{l}-0.025 \\
(0.069)\end{array}$ \\
\hline Control Mean: Post-Reform Stock Cs & 0.191 & 0.191 & 0.191 & Control Mean: Post-Reform Stock Cs & 0.085 & 0.085 & 0.085 \\
\hline Control Mean: Post-Reform LLCs & 0.242 & $\mathrm{n} / \mathrm{a}$ & $\mathrm{n} / \mathrm{a}$ & Control Mean: Post-Reform LLCs & 0.075 & $\mathrm{n} / \mathrm{a}$ & $\mathrm{n} / \mathrm{a}$ \\
\hline H: Transportation and storage & $\begin{array}{c}0.019 \\
(0.025)\end{array}$ & $\begin{array}{c}0.023 \\
(0.025)\end{array}$ & $\begin{array}{c}0.045 \\
(0.046)\end{array}$ & R: Arts, entertainment, and recreation & $\begin{array}{c}0.007 \\
(0.013)\end{array}$ & $\begin{array}{c}0.004 \\
(0.013)\end{array}$ & $\times$ \\
\hline Control Mean: Post-Reform Stock Cs & 0.021 & 0.021 & 0.021 & Control Mean: Post-Reform Stock Cs & 0.007 & 0.007 & \\
\hline Control Mean: Post-Reform LLCs & 0.052 & $\mathrm{n} / \mathrm{a}$ & $\mathrm{n} / \mathrm{a}$ & Control Mean: Post-Reform LLCs & 0.011 & $\mathrm{n} / \mathrm{a}$ & \\
\hline J: Information and communication & $\begin{array}{c}0.057 \\
(0.056)\end{array}$ & $\begin{array}{c}0.053 \\
(0.056)\end{array}$ & $\begin{array}{c}-0.031 \\
(0.109)\end{array}$ & S: Other services activities & $\begin{array}{c}-0.004 \\
(0.007)\end{array}$ & $\begin{array}{c}-0.007 \\
(0.007)\end{array}$ & $\times$ \\
\hline Control Mean: Post-Reform Stock Cs & 0.191 & 0.191 & 0.191 & Control Mean: Post-Reform Stock Cs & 0.007 & 0.007 & \\
\hline \multirow[t]{2}{*}{ Control Mean: Post-Reform LLCs } & 0.056 & $\mathrm{n} / \mathrm{a}$ & $\mathrm{n} / \mathrm{a}$ & Control Mean: Post-Reform LLCs & 0.017 & $\mathrm{n} / \mathrm{a}$ & \\
\hline & & & & $\begin{array}{l}N, \text { Firms } \\
N, \text { Stock Cs. } \\
N, \text { LLCs } \\
\text { Joint P-Value }\end{array}$ & $\begin{array}{c}12,874 \\
231 \\
12,643 \\
0.384\end{array}$ & $\begin{array}{c}231 \\
231 \\
\mathrm{n} / \mathrm{a} \\
0.396\end{array}$ & $\begin{array}{c}231 \\
231 \\
\mathrm{n} / \mathrm{a} \\
0.828\end{array}$ \\
\hline
\end{tabular}

Note: This table reports estimates of the effect of shared governance on the industry composition of stock corporations. Formally, we use indicators for each NACE Rev. 2 Classification 1 industry code as outcomes for $\mathrm{DiD}$ specifications as in equation (2). Some industries are excluded due to insufficient observations among stock corporations. Column "DiD" reports the basic specification from equation (2), column "Diff" reports the basic specification from (1) and column "RD" reports results from basic specification of (3). The $\mathrm{RD}$ design has missing entries indicated by $\times$ as those cells had zero observations in those industries among young stock corporations. We visually report all estimates in Panel (c) of Figure. Stars denote statistical significance: ${ }^{*} p<0.10,{ }^{* *} p<0.05,{ }^{* * *} p<0.01$. Figure 3 Panel b plots the underlying data. 3 . 
Table A.3: Effects on the Wage Distribution

\begin{tabular}{|c|c|c|c|c|c|c|c|c|c|}
\hline \multirow{2}{*}{$\begin{array}{l}\text { Outcome } \\
\text { Percentile }\end{array}$} & \multicolumn{8}{|c|}{ Mean Log Wage } & \multirow[b]{2}{*}{ p90 } \\
\hline & p10 & p20 & p30 & $\mathrm{p} 40$ & p50 & p60 & p70 & p80 & \\
\hline \multicolumn{10}{|c|}{ Panel A: Actual Reform (1994) } \\
\hline $\begin{array}{l}\text { Difference } \\
\text { Industry-Year FE }\end{array}$ & $\begin{array}{c}0.006 \\
(0.074)\end{array}$ & $\begin{array}{l}-0.026 \\
(0.061)\end{array}$ & $\begin{array}{l}-0.019 \\
(0.052)\end{array}$ & $\begin{array}{l}-0.012 \\
(0.046)\end{array}$ & $\begin{array}{l}-0.013 \\
(0.043)\end{array}$ & $\begin{array}{l}-0.014 \\
(0.041)\end{array}$ & $\begin{array}{l}-0.010 \\
(0.039)\end{array}$ & $\begin{array}{l}-0.003 \\
(0.035)\end{array}$ & $\begin{array}{l}-0.004 \\
(0.029)\end{array}$ \\
\hline $\begin{array}{l}\mathrm{DiD} \\
\text { Industry-Year FE }\end{array}$ & $\begin{array}{c}0.024 \\
(0.063)\end{array}$ & $\begin{array}{l}-0.001 \\
(0.053)\end{array}$ & $\begin{array}{l}-0.004 \\
(0.047)\end{array}$ & $\begin{array}{c}0.001 \\
(0.042)\end{array}$ & $\begin{array}{c}0.003 \\
(0.040)\end{array}$ & $\begin{array}{c}0.004 \\
(0.039)\end{array}$ & $\begin{array}{c}0.006 \\
(0.037)\end{array}$ & $\begin{array}{c}0.009 \\
(0.033)\end{array}$ & $\begin{array}{c}0.004 \\
(0.028)\end{array}$ \\
\hline $\begin{array}{l}\text { RD } \\
\text { Industry-Year FE }\end{array}$ & $\begin{array}{c}0.199 \\
(0.151)\end{array}$ & $\begin{array}{c}0.095 \\
(0.128)\end{array}$ & $\begin{array}{c}0.045 \\
(0.109)\end{array}$ & $\begin{array}{c}0.049 \\
(0.100)\end{array}$ & $\begin{array}{c}0.045 \\
(0.096)\end{array}$ & $\begin{array}{c}0.050 \\
(0.095)\end{array}$ & $\begin{array}{c}0.052 \\
(0.090)\end{array}$ & $\begin{array}{c}0.039 \\
(0.083)\end{array}$ & $\begin{array}{c}0.021 \\
(0.072)\end{array}$ \\
\hline Control Mean: Stock Cs & 3.953 & 4.284 & 4.456 & 4.574 & 4.672 & 4.758 & 4.845 & 4.941 & 5.051 \\
\hline$N$, Stock Cs & 229 & 229 & 229 & 229 & 229 & 229 & 229 & 229 & 229 \\
\hline$N$, Firm-Years Stock Cs & 3,179 & 3,179 & 3,179 & 3,179 & 3,179 & 3,179 & 3,179 & 3,179 & 3,179 \\
\hline Control Mean: LLCs & 3.823 & 4.097 & 4.248 & 4.351 & 4.434 & 4.509 & 4.586 & 4.675 & 4.802 \\
\hline$N$, LLCs & 12,639 & 12,639 & 12,639 & 12,639 & 12,639 & 12,639 & 12,639 & 12,639 & 12,639 \\
\hline$N$, Firm-Years LLCs & 146,289 & 146,289 & 146,289 & 146,289 & 146,289 & 146,289 & 146,289 & 146,289 & 146,289 \\
\hline \multicolumn{10}{|c|}{ Panel B: Placebo Reform 1996} \\
\hline $\begin{array}{l}\text { Difference } \\
\text { Industry-Year FE }\end{array}$ & $\begin{array}{l}-0.016 \\
(0.062)\end{array}$ & $\begin{array}{c}0.018 \\
(0.054)\end{array}$ & $\begin{array}{c}0.011 \\
(0.049)\end{array}$ & $\begin{array}{l}-0.001 \\
(0.046)\end{array}$ & $\begin{array}{l}-0.009 \\
(0.044)\end{array}$ & $\begin{array}{l}-0.022 \\
(0.041)\end{array}$ & $\begin{array}{l}-0.033 \\
(0.037)\end{array}$ & $\begin{array}{l}-0.030 \\
(0.033)\end{array}$ & $\begin{array}{l}-0.025 \\
(0.026)\end{array}$ \\
\hline $\begin{array}{l}\text { DiD } \\
\text { Industry-Year FE }\end{array}$ & $\begin{array}{l}-0.047 \\
(0.057)\end{array}$ & $\begin{array}{l}-0.001 \\
(0.050)\end{array}$ & $\begin{array}{l}-0.001 \\
(0.045)\end{array}$ & $\begin{array}{l}-0.010 \\
(0.042)\end{array}$ & $\begin{array}{l}-0.019 \\
(0.040)\end{array}$ & $\begin{array}{l}-0.027 \\
(0.038)\end{array}$ & $\begin{array}{l}-0.037 \\
(0.036)\end{array}$ & $\begin{array}{l}-0.033 \\
(0.033)\end{array}$ & $\begin{array}{l}-0.031 \\
(0.027)\end{array}$ \\
\hline $\mathrm{RD}$ & 0.113 & 0.077 & 0.064 & 0.071 & 0.047 & 0.024 & 0.018 & 0.024 & 0.021 \\
\hline Industry-Year FE & $(0.126)$ & $(0.110)$ & $(0.099)$ & $(0.093)$ & $(0.087)$ & $(0.081)$ & $(0.075)$ & $(0.066)$ & $(0.051)$ \\
\hline Control Mean: Stock Cs & 3.968 & 4.267 & 4.448 & 4.584 & 4.695 & 4.792 & 4.889 & 4.980 & 5.083 \\
\hline$N$, Stock Cs & 327 & 327 & 327 & 327 & 327 & 327 & 327 & 327 & 327 \\
\hline$N$, Firm-Years Stock Cs & 4,001 & 4,001 & 4,001 & 4,001 & 4,001 & 4,001 & 4,001 & 4,001 & 4,001 \\
\hline Control Mean: LLCs & 3.808 & 4.083 & 4.235 & 4.340 & 4.424 & 4.500 & 4.579 & 4.669 & 4.795 \\
\hline$N$, LLCs & 13,574 & 13,574 & 13,574 & 13,574 & 13,574 & 13,574 & 13,574 & 13,574 & 13,574 \\
\hline$N$, Firm-Years LLCs & 143,087 & 143,087 & 143,087 & 143,087 & 143,087 & 143,087 & 143,087 & 143,087 & 143,087 \\
\hline \multicolumn{10}{|c|}{ Panel C: Placebo Reform 1997} \\
\hline $\begin{array}{l}\text { Difference } \\
\text { Industry-Year FE }\end{array}$ & $\begin{array}{c}0.062 \\
(0.056)\end{array}$ & $\begin{array}{c}0.061 \\
(0.049)\end{array}$ & $\begin{array}{c}0.040 \\
(0.044)\end{array}$ & $\begin{array}{c}0.036 \\
(0.040)\end{array}$ & $\begin{array}{c}0.044 \\
(0.037)\end{array}$ & $\begin{array}{c}0.047 \\
(0.034)\end{array}$ & $\begin{array}{c}0.046 \\
(0.031)\end{array}$ & $\begin{array}{c}0.041 \\
(0.027)\end{array}$ & $\begin{array}{c}0.033 \\
(0.022)\end{array}$ \\
\hline $\begin{array}{l}\mathrm{DiD} \\
\text { Industry-Year FE }\end{array}$ & $\begin{array}{c}0.042 \\
(0.051)\end{array}$ & $\begin{array}{c}0.046 \\
(0.045)\end{array}$ & $\begin{array}{c}0.026 \\
(0.040)\end{array}$ & $\begin{array}{c}0.017 \\
(0.037)\end{array}$ & $\begin{array}{c}0.019 \\
(0.035)\end{array}$ & $\begin{array}{c}0.019 \\
(0.033)\end{array}$ & $\begin{array}{c}0.015 \\
(0.031)\end{array}$ & $\begin{array}{c}0.007 \\
(0.028)\end{array}$ & $\begin{array}{c}0.001 \\
(0.023)\end{array}$ \\
\hline $\mathrm{RD}$ & 0.002 & -0.013 & -0.068 & -0.073 & -0.054 & -0.048 & -0.046 & -0.052 & -0.041 \\
\hline Industry-Year FE & $(0.113)$ & $(0.099)$ & $(0.091)$ & $(0.083)$ & $(0.077)$ & $(0.072)$ & $(0.064)$ & $(0.055)$ & $(0.044)$ \\
\hline Control Mean: Stock Cs & 3.922 & 4.242 & 4.431 & 4.567 & 4.674 & 4.769 & 4.864 & 4.958 & 5.062 \\
\hline$N$, Stock Cs & 456 & 456 & 456 & 456 & 456 & 456 & 456 & 456 & 456 \\
\hline$N$, Firm-Years Stock Cs & 5,184 & 5,184 & 5,184 & 5,184 & 5,184 & 5,184 & 5,184 & 5,184 & 5,184 \\
\hline Control Mean: LLCs & 3.791 & 4.068 & 4.220 & 4.324 & 4.407 & 4.484 & 4.562 & 4.652 & 4.778 \\
\hline$N$, LLCs & 14,770 & 14,770 & 14,770 & 14,770 & 14,770 & 14,770 & 14,770 & 14,770 & 14,770 \\
\hline$N$, Firm-Years LLCs & 148,565 & 148,565 & 148,565 & 148,565 & 148,565 & 148,565 & 148,565 & 148,565 & 148,565 \\
\hline
\end{tabular}

Note: The table reports the effect of shared governance on the within-firm wage distribution, using as outcome variables the deciles of the intra-firm log wage distribution in a given year. The first row reports the effect of shared governance, $\hat{\gamma}^{\text {Diff }}$, in simple difference specifications (1) comparing stock corporations incorporated in a two-year window before vs. after the August 10, 1994 cutoff date. The second row reports difference-in-differences results, $\hat{\gamma}^{\mathrm{DiD}}$ in Equation 22, additionally drawing on LLCs (a legal form unaffected by the 1994 reform) as a control group. The third row reports RD specifications, i.e. estimates of $\hat{\gamma}^{\mathrm{RD}}$ in Equation (3). We use 2-digit NACE designations to create industry-year fixed effects. All outcomes are winsorized at the $1 \%$ level by year. Standard errors are clustered at the firm level are reported in parentheses. Stars denote statistical significance: ${ }^{*} p<0.10,{ }^{* *} p<0.05,{ }^{* * *} p<0.01$. 
Table A.4: Placebo: Effect of Shared Governance on Wages (Placebo Reforms in 1996 and 1997)

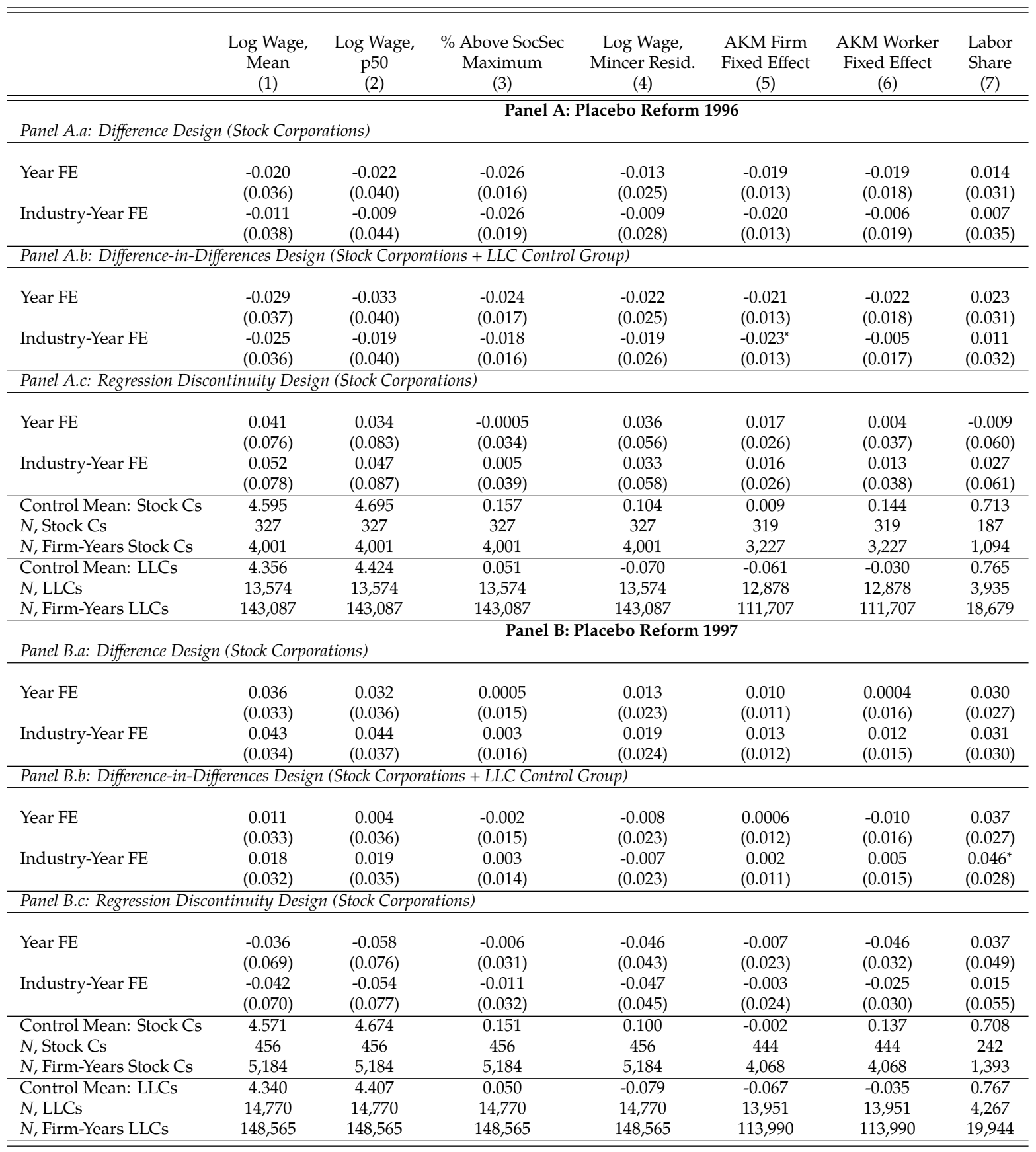

Note: The table reports placebo specifications for the effect of shared governance on wages. Panel A reports results for a counterfactual reform on August 10, 1996, Panel B for a placebo reform on August 10, 1997. Panel A.a and B.a reports the effect of shared governance, $\hat{\gamma}^{\text {Diff, }}$, in simple difference specifications (1) comparing stock corporations incorporated in a two-year window before vs. after the August 10, 1994 cutoff date. Panels A.b and B.b report difference-in-differences results, $\hat{\gamma}^{\mathrm{DiD}}$ in Equation (2), additionally drawing on LLCs (a legal form unaffected by the 1994 reform) as a control group. Panels A.c and B.c report estimates $\hat{\gamma}^{\mathrm{RD}}$ from the RD specifications in Equation (3). We use 2-digit NACE designations to create industry-year fixed effects. All outcomes are winsorized at the $1 \%$ level by year. The control means refer to observations of firms incorporated on or after August 10, 1994. Standard errors are clustered at the firm level are reported in parentheses. Stars denote statistical significance: ${ }^{*} p<0.10$, ${ }^{* *} p<0.05$, ${ }^{* * *} p<0.01$. We report main estimates in Table 1 
Table A.5: Effect of Shared Governance on Wages (Non-Missing Fixed Assets)

\begin{tabular}{|c|c|c|c|c|c|c|c|}
\hline & $\begin{array}{l}\text { Log Wage, } \\
\text { Mean } \\
(1)\end{array}$ & $\begin{array}{l}\text { Log Wage, } \\
\text { p50 } \\
(2)\end{array}$ & $\begin{array}{l}\text { \% Above SocSec } \\
\text { Maximum } \\
(3)\end{array}$ & $\begin{array}{l}\text { Log Wage, } \\
\text { Mincer Resid. } \\
(4)\end{array}$ & $\begin{array}{l}\text { AKM Firm } \\
\text { Fixed Effect } \\
\quad(5)\end{array}$ & $\begin{array}{l}\text { AKM Worker } \\
\text { Fixed Effect } \\
(6) \\
\end{array}$ & $\begin{array}{l}\text { Labor } \\
\text { Share } \\
(7)\end{array}$ \\
\hline \multicolumn{8}{|c|}{ Panel A: Difference Design (Stock Corporations) } \\
\hline Year FE & $\begin{array}{c}0.025 \\
(0.046)\end{array}$ & $\begin{array}{c}0.041 \\
(0.048)\end{array}$ & $\begin{array}{c}0.018 \\
(0.020)\end{array}$ & $\begin{array}{c}-0.004 \\
(0.031)\end{array}$ & $\begin{array}{c}0.013 \\
(0.016)\end{array}$ & $\begin{array}{c}0.014 \\
(0.024)\end{array}$ & $\begin{array}{c}-0.029 \\
(0.034)\end{array}$ \\
\hline Industry-Year FE & $\begin{array}{c}-0.018 \\
(0.045)\end{array}$ & $\begin{array}{c}-0.013 \\
(0.047)\end{array}$ & $\begin{array}{c}-0.002 \\
(0.021)\end{array}$ & $\begin{array}{c}-0.026 \\
(0.034)\end{array}$ & $\begin{array}{c}0.001 \\
(0.016)\end{array}$ & $\begin{array}{c}-0.013 \\
(0.022)\end{array}$ & $\begin{array}{c}-0.034 \\
(0.035)\end{array}$ \\
\hline \multicolumn{8}{|c|}{ Panel B: Difference-in-Differences Design (Stock Corporations + LLC Control Group) } \\
\hline Year FE & $\begin{array}{c}0.019 \\
(0.046)\end{array}$ & $\begin{array}{c}0.037 \\
(0.048)\end{array}$ & $\begin{array}{c}0.018 \\
(0.020)\end{array}$ & $\begin{array}{c}-0.008 \\
(0.032)\end{array}$ & $\begin{array}{c}0.013 \\
(0.016)\end{array}$ & $\begin{array}{c}0.013 \\
(0.024)\end{array}$ & $\begin{array}{c}-0.035 \\
(0.035)\end{array}$ \\
\hline Industry-Year FE & $\begin{array}{c}0.005 \\
(0.042)\end{array}$ & $\begin{array}{c}0.010 \\
(0.044)\end{array}$ & $\begin{array}{c}0.009 \\
(0.018)\end{array}$ & $\begin{array}{c}-0.016 \\
(0.031)\end{array}$ & $\begin{array}{c}0.015 \\
(0.016)\end{array}$ & $\begin{array}{c}-0.010 \\
(0.020)\end{array}$ & $\begin{array}{c}-0.033 \\
(0.033)\end{array}$ \\
\hline \multicolumn{8}{|c|}{ Panel C: Regression Discontinuity Design (Stock Corporations) } \\
\hline Year FE & $\begin{array}{c}0.069 \\
(0.098)\end{array}$ & $\begin{array}{c}0.032 \\
(0.102)\end{array}$ & $\begin{array}{c}0.014 \\
(0.043)\end{array}$ & $\begin{array}{c}0.000 \\
(0.069)\end{array}$ & $\begin{array}{c}0.015 \\
(0.034)\end{array}$ & $\begin{array}{c}-0.010 \\
(0.049)\end{array}$ & $\begin{array}{c}-0.029 \\
(0.069)\end{array}$ \\
\hline Industry-Year FE & $\begin{array}{c}0.056 \\
(0.101)\end{array}$ & $\begin{array}{c}0.038 \\
(0.104)\end{array}$ & $\begin{array}{c}0.021 \\
(0.050)\end{array}$ & $\begin{array}{c}-0.019 \\
(0.074)\end{array}$ & $\begin{array}{c}0.001 \\
(0.037)\end{array}$ & $\begin{array}{c}0.006 \\
(0.047)\end{array}$ & $\begin{array}{c}0.025 \\
(0.067)\end{array}$ \\
\hline $\begin{array}{l}\text { Control Mean: Stock Cs } \\
N \text {, Stock Cs } \\
N \text {, Firm-Years Stock Cs }\end{array}$ & $\begin{array}{c}4.567 \\
217 \\
1,548\end{array}$ & $\begin{array}{l}4.665 \\
217 \\
1,548\end{array}$ & $\begin{array}{c}0.131 \\
217 \\
1,548\end{array}$ & $\begin{array}{c}0.100 \\
217 \\
1,548\end{array}$ & $\begin{array}{c}-0.007 \\
212 \\
1,275\end{array}$ & $\begin{array}{c}0.123 \\
212 \\
1,275\end{array}$ & $\begin{array}{c}0.728 \\
151 \\
920\end{array}$ \\
\hline $\begin{array}{l}\text { Control Mean: LLCs } \\
N \text {, LLCs } \\
N \text {, Firm-Years LLCs }\end{array}$ & $\begin{array}{c}4.342 \\
11,491 \\
72,988\end{array}$ & $\begin{array}{c}4.414 \\
11,491 \\
72,988\end{array}$ & $\begin{array}{c}0.049 \\
11,491 \\
72,988\end{array}$ & $\begin{array}{l}-0.053 \\
11,491 \\
72,988\end{array}$ & $\begin{array}{l}-0.057 \\
11,011 \\
58,278\end{array}$ & $\begin{array}{l}-0.032 \\
11,011 \\
58,278\end{array}$ & $\begin{array}{c}0.756 \\
3,675 \\
17,855\end{array}$ \\
\hline
\end{tabular}

Note: This table replicates Table 1 for non-missing firm-year BvD observations of fixed assets. 


\section{Table A.6: Effect of Shared Governance on Wages (Non-Missing Value Added per Worker)}

\begin{tabular}{|c|c|c|c|c|c|c|c|}
\hline & $\begin{array}{l}\text { Log Wage, } \\
\text { Mean } \\
(1)\end{array}$ & $\begin{array}{l}\text { Log Wage, } \\
\text { p50 } \\
(2)\end{array}$ & $\begin{array}{l}\text { \% Above SocSec } \\
\text { Maximum } \\
\text { (3) }\end{array}$ & $\begin{array}{c}\text { Log Wage, } \\
\text { Mincer Resid. } \\
(4)\end{array}$ & $\begin{array}{l}\text { AKM Firm } \\
\text { Fixed Effect } \\
\text { (5) }\end{array}$ & $\begin{array}{l}\text { AKM Worker } \\
\text { Fixed Effect } \\
(6)\end{array}$ & $\begin{array}{l}\text { Labor } \\
\text { Share } \\
(7)\end{array}$ \\
\hline \multicolumn{8}{|c|}{ Panel A: Difference Design (Stock Corporations) } \\
\hline Year FE & $\begin{array}{c}-0.002 \\
(0.055)\end{array}$ & $\begin{array}{c}0.023 \\
(0.060)\end{array}$ & $\begin{array}{c}0.012 \\
(0.026)\end{array}$ & $\begin{array}{c}-0.023 \\
(0.036)\end{array}$ & $\begin{array}{c}0.003 \\
(0.020)\end{array}$ & $\begin{array}{c}0.004 \\
(0.028)\end{array}$ & $\begin{array}{c}-0.032 \\
(0.035)\end{array}$ \\
\hline Industry-Year FE & $\begin{array}{c}-0.042 \\
(0.056)\end{array}$ & $\begin{array}{c}-0.032 \\
(0.058)\end{array}$ & $\begin{array}{c}-0.018 \\
(0.027)\end{array}$ & $\begin{array}{c}-0.035 \\
(0.039)\end{array}$ & $\begin{array}{c}0.001 \\
(0.020)\end{array}$ & $\begin{array}{c}-0.034 \\
(0.028)\end{array}$ & $\begin{array}{l}-0.040 \\
(0.035)\end{array}$ \\
\hline \multicolumn{8}{|c|}{ Panel B: Difference-in-Differences Design (Stock Corporations + LLC Control Group) } \\
\hline Year FE & $\begin{array}{c}0.008 \\
(0.056)\end{array}$ & $\begin{array}{c}0.034 \\
(0.060)\end{array}$ & $\begin{array}{c}0.016 \\
(0.026)\end{array}$ & $\begin{array}{c}-0.013 \\
(0.037)\end{array}$ & $\begin{array}{c}0.009 \\
(0.020)\end{array}$ & $\begin{array}{c}0.005 \\
(0.029)\end{array}$ & $\begin{array}{c}-0.039 \\
(0.035)\end{array}$ \\
\hline Industry-Year FE & $\begin{array}{c}-0.009 \\
(0.049)\end{array}$ & $\begin{array}{c}0.003 \\
(0.053)\end{array}$ & $\begin{array}{c}-0.000 \\
(0.023)\end{array}$ & $\begin{array}{c}-0.018 \\
(0.036)\end{array}$ & $\begin{array}{c}0.012 \\
(0.019)\end{array}$ & $\begin{array}{l}-0.016 \\
(0.024)\end{array}$ & $\begin{array}{l}-0.037 \\
(0.033)\end{array}$ \\
\hline \multicolumn{8}{|c|}{ Panel C: Regression Discontinuity Design (Stock Corporations) } \\
\hline Year FE & $\begin{array}{c}0.102 \\
(0.122)\end{array}$ & $\begin{array}{c}0.051 \\
(0.131)\end{array}$ & $\begin{array}{c}-0.010 \\
(0.056)\end{array}$ & $\begin{array}{c}0.063 \\
(0.084)\end{array}$ & $\begin{array}{c}0.013 \\
(0.045)\end{array}$ & $\begin{array}{c}-0.012 \\
(0.058)\end{array}$ & $\begin{array}{c}-0.035 \\
(0.069)\end{array}$ \\
\hline Industry-Year FE & $\begin{array}{c}0.094 \\
(0.123)\end{array}$ & $\begin{array}{c}0.074 \\
(0.134)\end{array}$ & $\begin{array}{c}-0.004 \\
(0.064)\end{array}$ & $\begin{array}{c}0.050 \\
(0.086)\end{array}$ & $\begin{array}{c}0.023 \\
(0.046)\end{array}$ & $\begin{array}{c}-0.003 \\
(0.058)\end{array}$ & $\begin{array}{c}0.014 \\
(0.067)\end{array}$ \\
\hline $\begin{array}{l}\text { Control Mean: Stock Cs } \\
N \text {, Stock Cs } \\
N \text {, Firm-Years Stock Cs }\end{array}$ & $\begin{array}{c}4.628 \\
146 \\
894\end{array}$ & $\begin{array}{c}4.716 \\
146 \\
894\end{array}$ & $\begin{array}{c}0.158 \\
146 \\
894\end{array}$ & $\begin{array}{c}0.143 \\
146 \\
894\end{array}$ & $\begin{array}{c}0.022 \\
144 \\
740\end{array}$ & $\begin{array}{c}0.134 \\
144 \\
740\end{array}$ & $\begin{array}{c}0.729 \\
146 \\
892\end{array}$ \\
\hline $\begin{array}{l}\text { Control Mean: LLCs } \\
N \text {, LLCs } \\
N \text {, Firm-Years LLCs }\end{array}$ & $\begin{array}{c}4.505 \\
3,524 \\
16,783\end{array}$ & $\begin{array}{c}4.558 \\
3,524 \\
16,783\end{array}$ & $\begin{array}{c}0.094 \\
3,524 \\
16,783\end{array}$ & $\begin{array}{c}0.075 \\
3,524 \\
16,783\end{array}$ & $\begin{array}{c}-0.003 \\
3,395 \\
14,211\end{array}$ & $\begin{array}{c}0.019 \\
3,395 \\
14,211\end{array}$ & $\begin{array}{c}0.754 \\
3,508 \\
16,707\end{array}$ \\
\hline
\end{tabular}

Note: This table replicates Table 1 for non-missing firm-year BvD observations of value added per worker. 
Table A.7: Placebo: Effect of Shared Governance on Labor Productivity and Capital Intensity (RD and Placebo Reforms in 1996 and 1997)

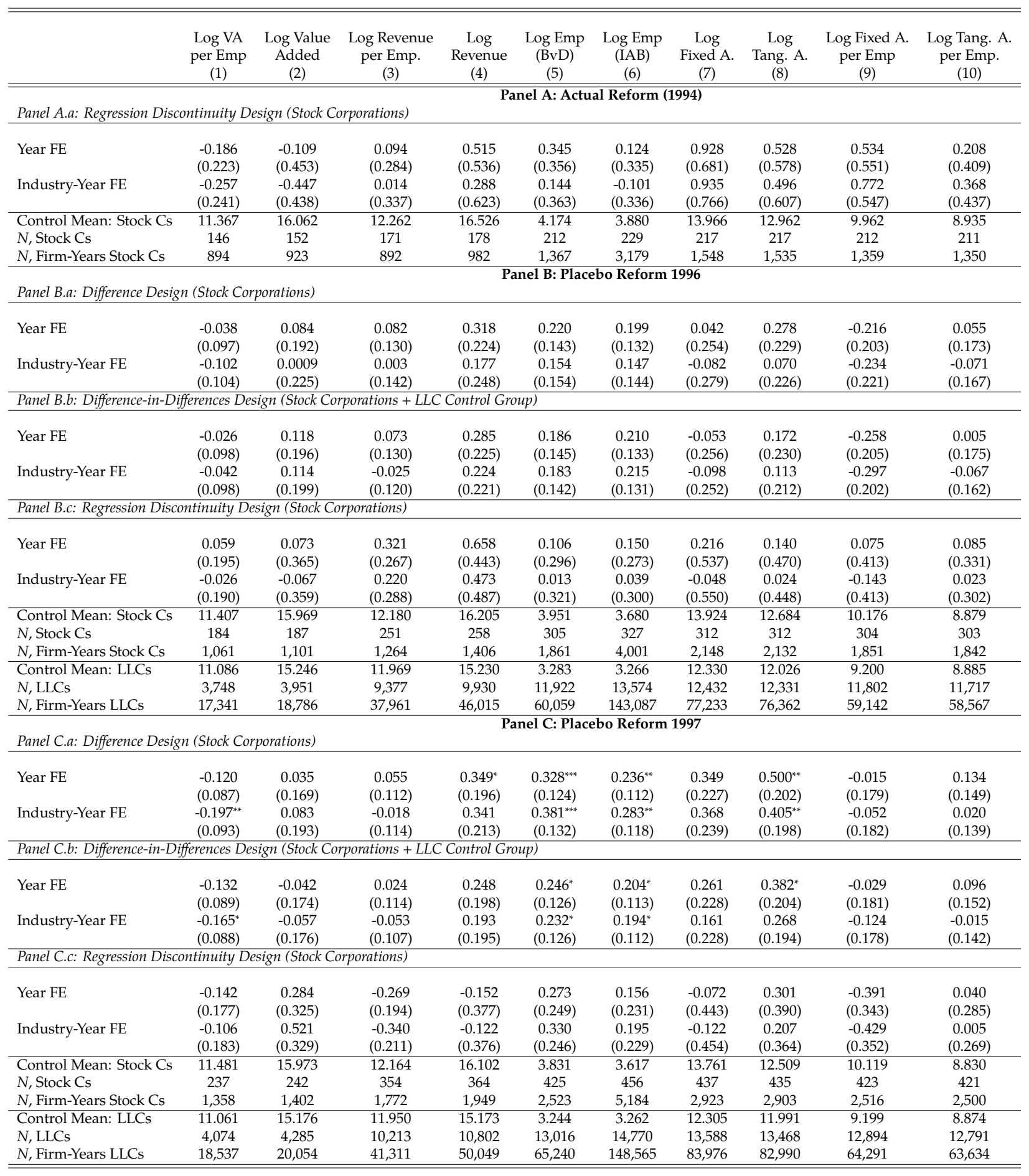

Note: This table replicates Table 2 for RD specifications (Panel A) and placebo reforms (Panel B and Panel C). 
Table A.8: Effect of Shared Governance on Profitability

\begin{tabular}{|c|c|c|c|c|c|c|}
\hline & $\begin{array}{c}\text { EBITDA } \\
\text { / Revenue } \\
\text { (1) }\end{array}$ & $\begin{array}{c}\text { EBIT } \\
\text { /Revenue } \\
\text { (2) }\end{array}$ & $\begin{array}{l}\text { Net Income } \\
\text { /Revenue } \\
\text { (3) }\end{array}$ & $\begin{array}{c}\text { EBITDA } \\
\text { /Total A. } \\
\text { (4) }\end{array}$ & $\begin{array}{c}\text { EBIT } \\
\text { /Total A. } \\
\text { (5) }\end{array}$ & $\begin{array}{l}\text { Net Income } \\
\text { /Total A. } \\
\text { (6) }\end{array}$ \\
\hline \multicolumn{7}{|c|}{ Panel A: Difference Design (Stock Corporations) } \\
\hline Year FE & $\begin{array}{c}0.004 \\
(0.015)\end{array}$ & $\begin{array}{l}-0.070 \\
(0.045)\end{array}$ & $\begin{array}{c}0.018 \\
(0.031)\end{array}$ & $\begin{array}{c}0.013 \\
(0.020)\end{array}$ & $\begin{array}{l}-0.009 \\
(0.020)\end{array}$ & $\begin{array}{l}-0.006 \\
(0.013)\end{array}$ \\
\hline Industry-Year FE & $\begin{array}{c}-0.011 \\
(0.020)\end{array}$ & $\begin{array}{c}-0.071 \\
(0.049)\end{array}$ & $\begin{array}{c}-0.012 \\
(0.037)\end{array}$ & $\begin{array}{c}0.003 \\
(0.023)\end{array}$ & $\begin{array}{c}-0.011 \\
(0.025)\end{array}$ & $\begin{array}{c}-0.010 \\
(0.015)\end{array}$ \\
\hline \multicolumn{7}{|c|}{ Panel B: Difference-in-Differences Design (Stock Corporations + LLC Control Group) } \\
\hline Year FE & $\begin{array}{c}0.007 \\
(0.015)\end{array}$ & $\begin{array}{l}-0.068 \\
(0.045)\end{array}$ & $\begin{array}{c}0.015 \\
(0.031)\end{array}$ & $\begin{array}{c}0.016 \\
(0.021)\end{array}$ & $\begin{array}{l}-0.008 \\
(0.021)\end{array}$ & $\begin{array}{l}-0.007 \\
(0.013)\end{array}$ \\
\hline Industry-Year FE & $\begin{array}{l}-0.004 \\
(0.015)\end{array}$ & $\begin{array}{l}-0.056 \\
(0.042)\end{array}$ & $\begin{array}{l}-0.000 \\
(0.029)\end{array}$ & $\begin{array}{c}0.006 \\
(0.021)\end{array}$ & $\begin{array}{c}-0.011 \\
(0.021)\end{array}$ & $\begin{array}{l}-0.009 \\
(0.013)\end{array}$ \\
\hline \multicolumn{7}{|c|}{ Panel C: Regression Discontinuity Design (Stock Corporations) } \\
\hline Year FE & $\begin{array}{c}0.007 \\
(0.027)\end{array}$ & $\begin{array}{c}0.084 \\
(0.081)\end{array}$ & $\begin{array}{l}-0.049 \\
(0.056)\end{array}$ & $\begin{array}{c}-0.072 \\
(0.049)\end{array}$ & $\begin{array}{l}-0.037 \\
(0.048)\end{array}$ & $\begin{array}{l}-0.033 \\
(0.029)\end{array}$ \\
\hline Industry-Year FE & $\begin{array}{l}-0.006 \\
(0.043)\end{array}$ & $\begin{array}{c}0.111 \\
(0.104)\end{array}$ & $\begin{array}{c}-0.092 \\
(0.085)\end{array}$ & $\begin{array}{l}-0.105^{*} \\
(0.059)\end{array}$ & $\begin{array}{l}-0.064 \\
(0.057)\end{array}$ & $\begin{array}{l}-0.042 \\
(0.035)\end{array}$ \\
\hline $\begin{array}{l}\text { Control Mean: Stock Cs } \\
N \text {, Stock Cs } \\
N \text {, Firm-Years Stock Cs }\end{array}$ & $\begin{array}{c}0.098 \\
124 \\
562\end{array}$ & $\begin{array}{c}0.013 \\
131 \\
715\end{array}$ & $\begin{array}{c}0.056 \\
131 \\
699\end{array}$ & $\begin{array}{c}0.162 \\
145 \\
772\end{array}$ & $\begin{array}{c}0.086 \\
152 \\
945\end{array}$ & $\begin{array}{l}0.057 \\
152 \\
929\end{array}$ \\
\hline $\begin{array}{l}\text { Control Mean: LLCs } \\
N \text {, LLCs } \\
N \text {, Firm-Years LLCs }\end{array}$ & $\begin{array}{c}0.083 \\
2,938 \\
11,160\end{array}$ & $\begin{array}{c}0.037 \\
3,060 \\
12,417\end{array}$ & $\begin{array}{c}0.024 \\
3,029 \\
11,898\end{array}$ & $\begin{array}{c}0.177 \\
3,597 \\
16,527\end{array}$ & $\begin{array}{c}0.104 \\
3,726 \\
18,228\end{array}$ & $\begin{array}{c}0.057 \\
3,697 \\
17,704\end{array}$ \\
\hline
\end{tabular}

Note: The table reports the effect of shared governance on measures of profitability. Panel A reports the effect of shared governance, $\hat{\gamma}^{\text {Diff }}$, in simple difference specifications (1) comparing stock corporations incorporated in a two-year window before vs. after the August 10, 1994 cutoff date. Panel B reports difference-in-differences results, $\hat{\gamma}^{\mathrm{DiD}}$ in Equation (2), additionally drawing on LLCs (a legal form unaffected by the 1994 reform) as a control group. Panel C reports estimates $\hat{\gamma}^{\mathrm{RD}}$ from the RD specifications in Equation (3). We use 2-digit NACE designations to create industry-year fixed effects. All outcomes are winsorized at the $1 \%$ level by year. The control means refer to observations of firms incorporated on or after August 10, 1994. Standard errors are clustered at the firm level are reported in parentheses. Stars denote statistical significance: ${ }^{*} p<0.10,{ }^{* *} p<0.05,{ }^{* * *} p<0.01$. Appendix Table A.9 reports effects of placebo reforms. 
Table A.9: Placebo: Effect of Shared Governance on Profitability (Placebo Reforms in 1996 and 1997)

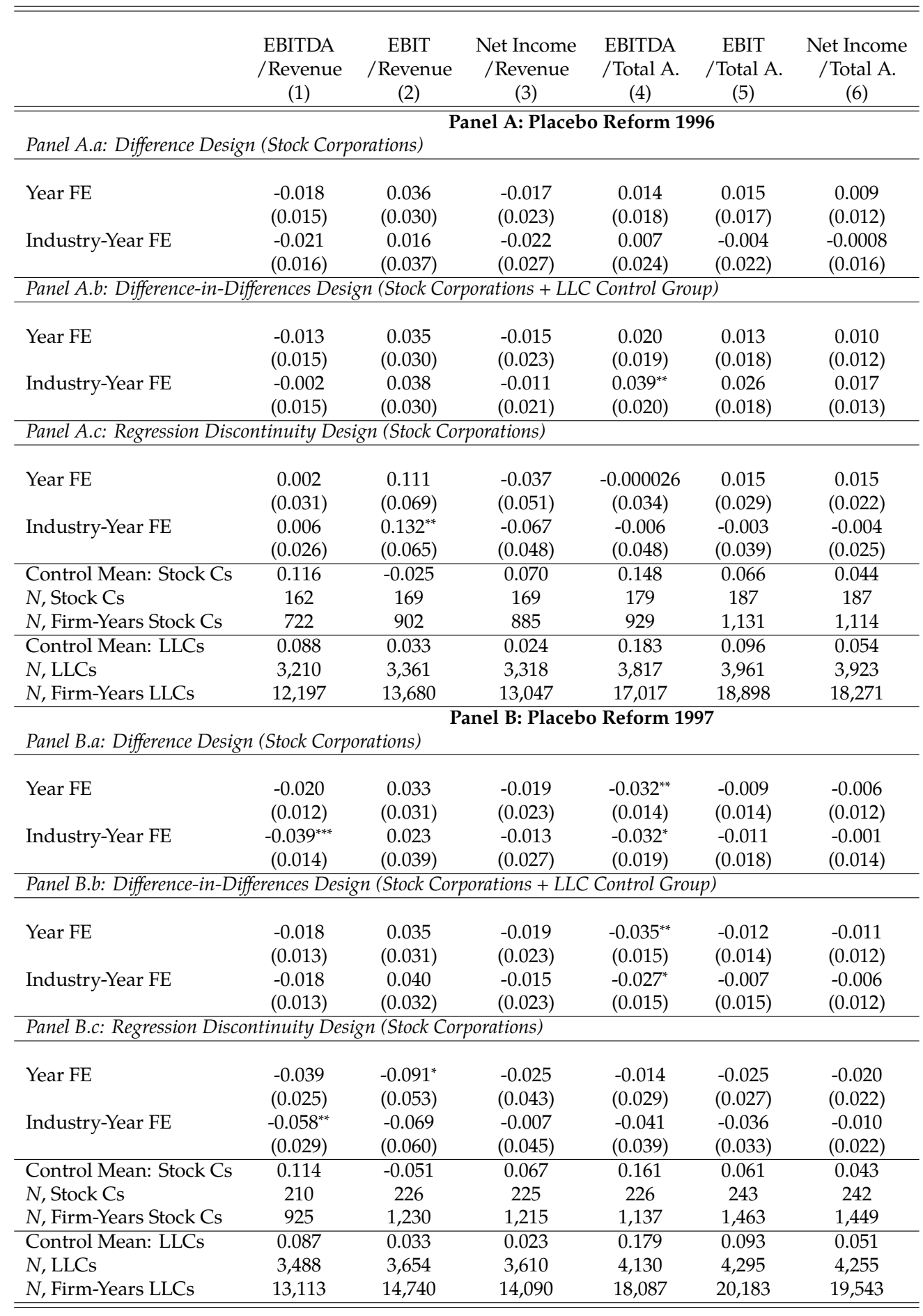

Note: This table replicates Table A.8 for the placebo reforms. 
Table A.10: Effect of Shared Governance on Skill Structure, Outsourcing, and Tenure (Matched EmployerEmployee Data)

\begin{tabular}{|c|c|c|c|c|c|c|c|c|}
\hline & $\begin{array}{l}\text { Low- } \\
\text { Skilled \% } \\
\quad(1)\end{array}$ & $\begin{array}{l}\text { Med- } \\
\text { Skilled \% } \\
\quad(2)\end{array}$ & $\begin{array}{l}\text { High- } \\
\text { Skilled \% } \\
\quad(3)\end{array}$ & $\begin{array}{l}\text { Outsourceable } \\
\text { (FSCL) \% } \\
(4)\end{array}$ & $\begin{array}{l}\text { Value Added } \\
\text { / Revenue } \\
\text { (5) }\end{array}$ & $\begin{array}{l}\log \\
\text { Tenure } \\
(6)\end{array}$ & $\begin{array}{c}\text { Tenure } \\
\text { (Years) } \\
(7)\end{array}$ & $\begin{array}{c}\text { Separation } \\
\text { Rate (Annual) } \\
(8)\end{array}$ \\
\hline \multicolumn{9}{|c|}{ Panel A: Difference Design (Stock Corporations) } \\
\hline Year FE & $\begin{array}{l}-0.019 \\
(0.031)\end{array}$ & $\begin{array}{c}0.001 \\
(0.024)\end{array}$ & $\begin{array}{c}0.017 \\
(0.038)\end{array}$ & $\begin{array}{l}-0.009 \\
(0.015)\end{array}$ & $\begin{array}{c}0.101 \\
(0.079)\end{array}$ & $\begin{array}{c}0.071 \\
(0.052)\end{array}$ & $\begin{array}{c}0.235 \\
(0.279)\end{array}$ & $\begin{array}{l}-0.003 \\
(0.006)\end{array}$ \\
\hline Industry-Year FE & $\begin{array}{c}0.006 \\
(0.031)\end{array}$ & $\begin{array}{c}0.010 \\
(0.027)\end{array}$ & $\begin{array}{l}-0.017 \\
(0.039)\end{array}$ & $\begin{array}{c}0.012 \\
(0.009)\end{array}$ & $\begin{array}{c}0.008 \\
(0.081)\end{array}$ & $\begin{array}{c}0.077 \\
(0.054)\end{array}$ & $\begin{array}{c}0.332 \\
(0.301)\end{array}$ & $\begin{array}{l}-0.001 \\
(0.007)\end{array}$ \\
\hline \multicolumn{9}{|c|}{ Panel B: Difference-in-Differences Design (Stock Corporations + LLC Control Group) } \\
\hline Year FE & $\begin{array}{l}-0.037 \\
(0.032)\end{array}$ & $\begin{array}{c}0.009 \\
(0.024)\end{array}$ & $\begin{array}{c}0.028 \\
(0.038)\end{array}$ & $\begin{array}{l}-0.016 \\
(0.016)\end{array}$ & $\begin{array}{c}0.091 \\
(0.079)\end{array}$ & $\begin{array}{l}-0.027 \\
(0.051)\end{array}$ & $\begin{array}{l}-0.206 \\
(0.282)\end{array}$ & $\begin{array}{c}0.002 \\
(0.006)\end{array}$ \\
\hline Industry-Year FE & $\begin{array}{c}0.005 \\
(0.030)\end{array}$ & $\begin{array}{c}0.006 \\
(0.024)\end{array}$ & $\begin{array}{c}-0.011 \\
(0.033)\end{array}$ & $\begin{array}{c}-0.000 \\
(0.016)\end{array}$ & $\begin{array}{c}0.003 \\
(0.063)\end{array}$ & $\begin{array}{c}0.009 \\
(0.049)\end{array}$ & $\begin{array}{c}-0.032 \\
(0.268)\end{array}$ & $\begin{array}{c}-0.002 \\
(0.006)\end{array}$ \\
\hline \multicolumn{9}{|c|}{ Panel C: Regression Discontinuity Design (Stock Corporations) } \\
\hline Year FE & $\begin{array}{c}0.004 \\
(0.062)\end{array}$ & $\begin{array}{c}0.043 \\
(0.048)\end{array}$ & $\begin{array}{l}-0.046 \\
(0.073)\end{array}$ & $\begin{array}{l}-0.001 \\
(0.028)\end{array}$ & $\begin{array}{l}-0.186 \\
(0.139)\end{array}$ & $\begin{array}{c}0.125 \\
(0.111)\end{array}$ & $\begin{array}{c}0.529 \\
(0.594)\end{array}$ & $\begin{array}{l}-0.009 \\
(0.014)\end{array}$ \\
\hline Industry-Year FE & $\begin{array}{l}-0.025 \\
(0.067)\end{array}$ & $\begin{array}{c}0.013 \\
(0.059)\end{array}$ & $\begin{array}{c}0.012 \\
(0.083)\end{array}$ & $\begin{array}{c}0.004 \\
(0.026)\end{array}$ & $\begin{array}{l}-0.225 \\
(0.145)\end{array}$ & $\begin{array}{c}0.067 \\
(0.109)\end{array}$ & $\begin{array}{c}0.288 \\
(0.554)\end{array}$ & $\begin{array}{l}-0.006 \\
(0.016)\end{array}$ \\
\hline $\begin{array}{l}\text { Control Mean: Stock Cs } \\
N \text {, Stock Cs } \\
N \text {, Firm-Years Stock Cs }\end{array}$ & $\begin{array}{c}0.293 \\
226 \\
2,947\end{array}$ & $\begin{array}{c}0.296 \\
226 \\
2,947\end{array}$ & $\begin{array}{c}0.411 \\
226 \\
2,947\end{array}$ & $\begin{array}{c}0.059 \\
229 \\
3,179\end{array}$ & $\begin{array}{c}0.463 \\
131 \\
694\end{array}$ & $\begin{array}{l}-4.457 \\
229 \\
3,179\end{array}$ & $\begin{array}{c}4.865 \\
229 \\
3,179\end{array}$ & $\begin{array}{c}0.095 \\
229 \\
3,179\end{array}$ \\
\hline $\begin{array}{l}\text { Control Mean: LLCs } \\
N \text {, LLCs } \\
N \text {, Firm-Years LLCs }\end{array}$ & $\begin{array}{c}0.493 \\
11,865 \\
124,016\end{array}$ & $\begin{array}{c}0.301 \\
11,865 \\
124,016\end{array}$ & $\begin{array}{c}0.205 \\
11,865 \\
124,016\end{array}$ & $\begin{array}{c}0.148 \\
12,639 \\
146,289\end{array}$ & $\begin{array}{c}0.345 \\
3,049 \\
12,316\end{array}$ & $\begin{array}{c}-4.330 \\
12,639 \\
146,289\end{array}$ & $\begin{array}{c}5.522 \\
12,639 \\
146,289\end{array}$ & $\begin{array}{c}0.105 \\
12,639 \\
146,289\end{array}$ \\
\hline
\end{tabular}

Note: The table reports the effect of shared governance on employer-reported education measures in the IAB data (namely (i) low-skilled workers with no vocational training, (ii) medium-skilled workers with a finished school degree and a vocational qualification, and (iii) high-skilled workers with a university degree), outsourcing (the share of workers in outsourceable low-skilled occupations (i.e. food, security, cleaning and logistics, following Goldschmidt and Schmieder, 2017), and the BvD-based value-added/revenue ratio as an inverse measure of outsourcing), and tenure and annual separation rates. Panel A reports the effect of shared governance, $\hat{\gamma}^{\text {Diff }}$, in simple difference specifications (1) comparing stock corporations incorporated in a two-year window before vs. after the August 10, 1994 cutoff date. Panel B reports difference-in-differences results, $\hat{\gamma}^{\mathrm{DiD}}$ in Equation (2), additionally drawing on LLCs (a legal form unaffected by the 1994 reform) as a control group. Panel $C$ reports estimates $\hat{\gamma}^{\mathrm{RD}}$ from the RD specifications in Equation (3). We use 2-digit NACE designations to create industry-year fixed effects. All outcomes are winsorized at the $1 \%$ level by year. The control means refer to observations of firms incorporated on or after August 10, 1994. Standard errors are clustered at the firm level are reported in parentheses. Stars denote statistical significance: ${ }^{*} p<0.10,{ }^{* *}$ $p<0.05,{ }^{* * *} p<0.01$. 
Table A.11: Heterogeneity of Shared Governance Effects on Wages

\begin{tabular}{|c|c|c|c|c|c|c|c|c|c|c|}
\hline \multirow{2}{*}{$\begin{array}{l}\text { Outcome } \\
\text { Cut }\end{array}$} & \multicolumn{2}{|c|}{ Control Means } & \multicolumn{4}{|c|}{ Mean Log Wage } & \multicolumn{4}{|c|}{ AKM Firm Fixed Effect } \\
\hline & \multirow{2}{*}{\multicolumn{2}{|c|}{$\begin{array}{l}\text { Below Median Ab } \\
\text { ock Corporations) }\end{array}$}} & \multicolumn{2}{|c|}{ Below Median } & \multicolumn{2}{|c|}{ Above Median } & \multirow{2}{*}{\multicolumn{2}{|c|}{ Below Median }} & \multicolumn{2}{|c|}{ Above Median } \\
\hline \multicolumn{7}{|c|}{ Panel A: Difference Design (Stock Corporations) } & & & & \\
\hline \multicolumn{11}{|c|}{ Panel B: Difference-in-Differences Design (Stock Corporations + LLC Control Group) } \\
\hline $\begin{array}{l}\text { CBA Coverage } \\
\text { Binding CBA Coverage } \\
\text { AKM Pay Premia SD } \\
\text { Industry AKM } \\
\text { Works Council } \\
\text { Log Value Added per Worker } \\
\text { Tenure }\end{array}$ & $\begin{array}{c}0.425 \\
0.108 \\
0.135 \\
0.059 \\
0.572 \\
10.916 \\
3.014\end{array}$ & $\begin{array}{c}0.796 \\
0.254 \\
0.161 \\
0.150 \\
0.835 \\
11.365 \\
6.562\end{array}$ & $\begin{array}{r}-0.050 \\
-0.009 \\
0.037 \\
-0.114 \\
-0.099 \\
-0.041 \\
-0.029\end{array}$ & $\begin{array}{l}(0.046) \\
(0.048) \\
(0.046) \\
(0.068) \\
(0.048) \\
(0.072) \\
(0.043)\end{array}$ & $\begin{array}{r}0.088 \\
0.018 \\
-0.052 \\
0.045 \\
0.116 \\
0.005 \\
0.053\end{array}$ & $\begin{array}{l}(0.065) \\
(0.061) \\
(0.064) \\
(0.044) \\
(0.057) \\
(0.043) \\
(0.040)\end{array}$ & $\begin{array}{r}-0.002 \\
0.004 \\
0.017 \\
-0.041 \\
-0.018 \\
-0.015 \\
0.010\end{array}$ & $\begin{array}{l}(0.018) \\
(0.019) \\
(0.018) \\
(0.028) \\
(0.019) \\
(0.032) \\
(0.016)\end{array}$ & $\begin{array}{r}0.028 \\
0.017 \\
-0.003 \\
0.028 \\
0.040 \\
0.015 \\
0.008\end{array}$ & $\begin{array}{l}(0.027) \\
(0.024) \\
(0.028) \\
(0.017) \\
(0.023) \\
(0.017) \\
(0.020)\end{array}$ \\
\hline \multicolumn{11}{|c|}{ Panel C: Regression Discontinuity Design (Stock Corporations) } \\
\hline $\begin{array}{l}\text { CBA Coverage } \\
\text { Binding CBA Coverage } \\
\text { AKM Pay Premia SD } \\
\text { Industry AKM } \\
\text { Works Council } \\
\text { Log Value Added per Worker } \\
\text { Tenure }\end{array}$ & $\begin{array}{c}0.425 \\
0.108 \\
0.135 \\
0.059 \\
0.572 \\
10.916 \\
3.014\end{array}$ & $\begin{array}{c}0.796 \\
0.254 \\
0.161 \\
0.150 \\
0.835 \\
11.365 \\
6.562\end{array}$ & $\begin{array}{c}0.099 \\
0.117 \\
0.181 \\
-0.160 \\
0.151 \\
-0.044 \\
0.080\end{array}$ & $\begin{array}{c}(0.128) \\
(0.141) \\
(0.127) \\
(0.128) \\
(0.136) \\
(0.133) \\
(0.103)\end{array}$ & $\begin{array}{c}0.058 \\
0.030 \\
-0.176 \\
0.187 \\
0.020 \\
0.152 \\
0.028\end{array}$ & $\begin{array}{c}(0.135) \\
(0.110) \\
(0.136) \\
(0.121) \\
(0.120) \\
(0.126) \\
(0.101)\end{array}$ & $\begin{array}{c}0.045 \\
0.031 \\
0.066 \\
-0.083 \\
0.040 \\
-0.039 \\
0.033\end{array}$ & $\begin{array}{c}(0.041) \\
(0.048) \\
(0.043) \\
(0.053) \\
(0.046) \\
(0.055) \\
(0.040)\end{array}$ & $\begin{array}{c}-0.020 \\
-0.009 \\
-0.095 \\
0.055 \\
-0.010 \\
0.049 \\
-0.028\end{array}$ & $\begin{array}{c}(0.057) \\
(0.047) \\
(0.057) \\
(0.041) \\
(0.050) \\
(0.039) \\
(0.043)\end{array}$ \\
\hline
\end{tabular}

Note: The table reports heterogeneity in the effect of shared governance on wage measures. The rows are labeled by the heterogeneity categories, which are calculated as averages at the three-digit industry (NACE) level (with CBA coverage and works council prevalence calculated based on the IAB Establishment Panel). For example, CBA coverage splits firms into two categories depending on whether their industry has above or below-median collective bargaining coverage. The reported coefficients correspond to the effect of shared governance in firms above or below the median for the relevant heterogeneity category. The underlying regression model (with interacted base effects) is a simple difference specification as in Equation (1) in Panel A, a difference-in-difference specification as in Equation (2) in Panel B, and an RD specification as in Equation (3) in Panel C. Across panels, the means of the sorting (heterogeneity) variables are calculated among stock corporations in a two-year bandwidth around the reform.. All specifications include 2-digit NACE industry-year effects. Standard errors are clustered at the firm level are reported in parentheses. Stars denote statistical significance: ${ }^{*} p<0.10,{ }^{* *} p<0.05,{ }^{* * *} p<0.01$. We plot our main graphical results in Figure 6 . 


\section{B Additional Figures}

Figure A.1: Frequency of Incorporation and Selection: MUP Data

(a) Frequency of Incorporation

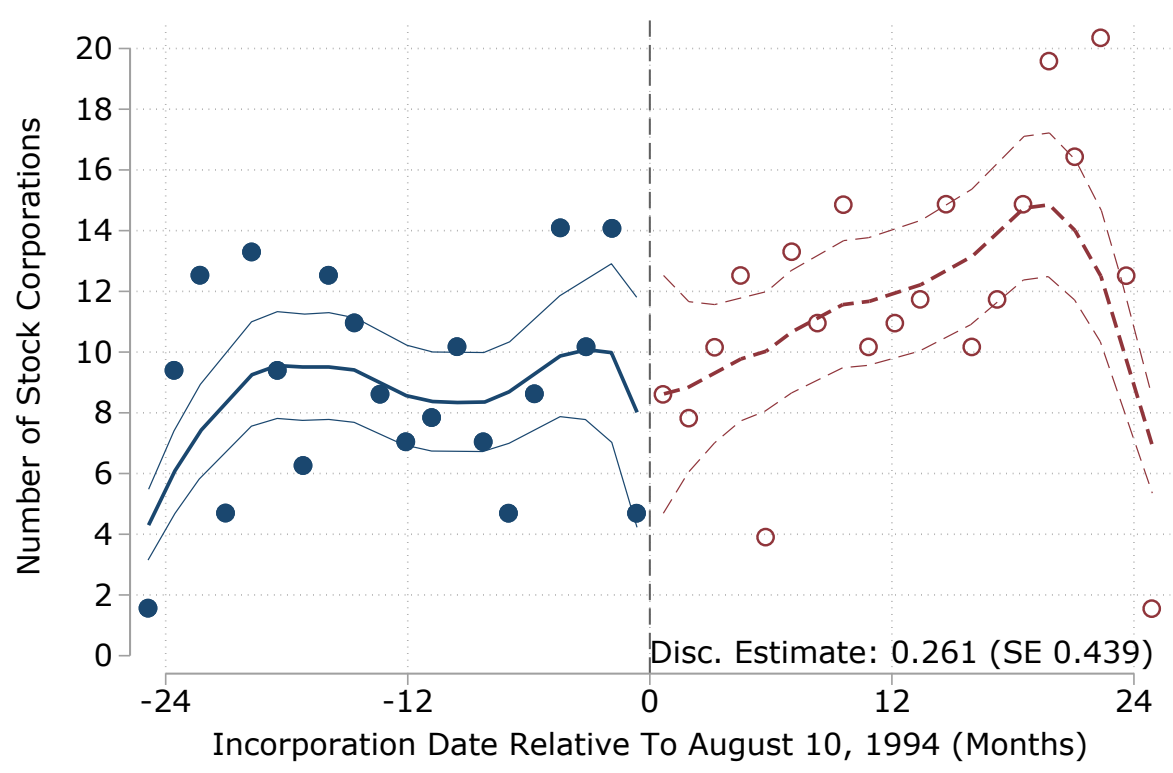

(b) Balance of Industry Composition

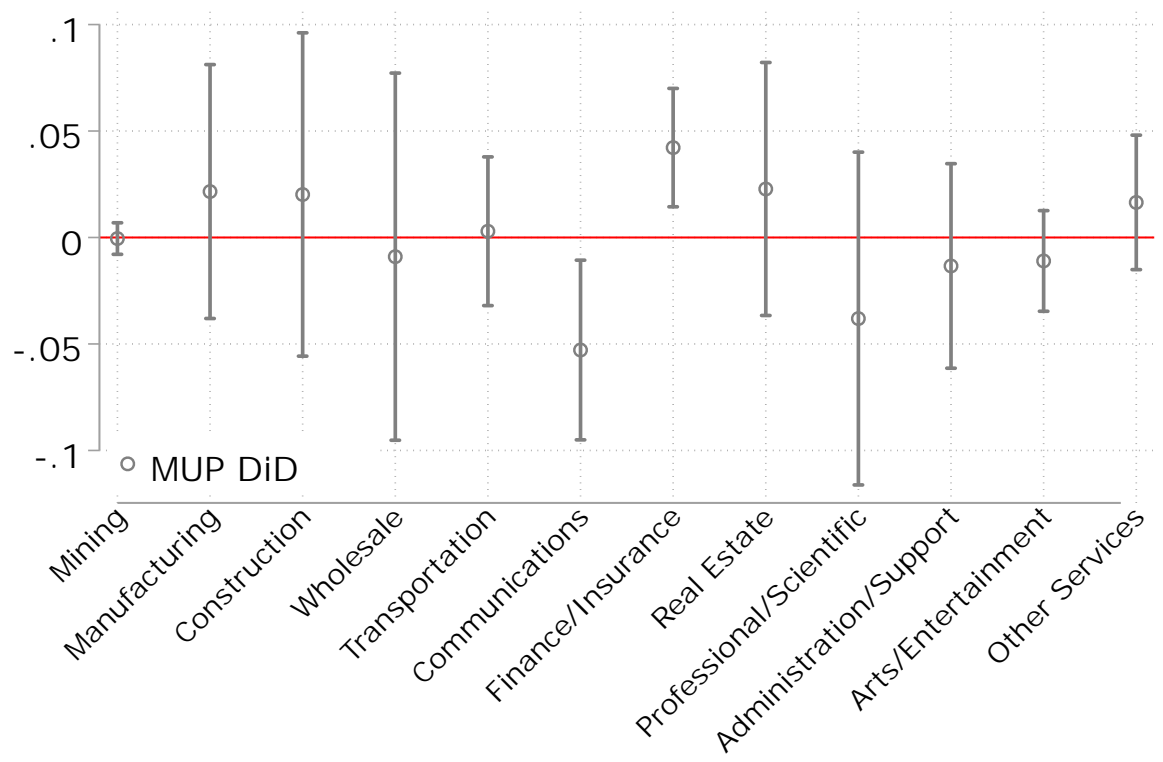

Note: This figure reports results analogous to Panels (a) and (c) in Figure 3 based on data from the Mannheim Enterprise Panel (MUP), which is available from 1991 onward. This figure does not contain the MUP version of Figure 3 Panel (b) or all specifications in Panel (c) of Figure 3 due to data access restrictions. See figure note for Figure 3 for additional information. 
(a) Survival Probability by Group

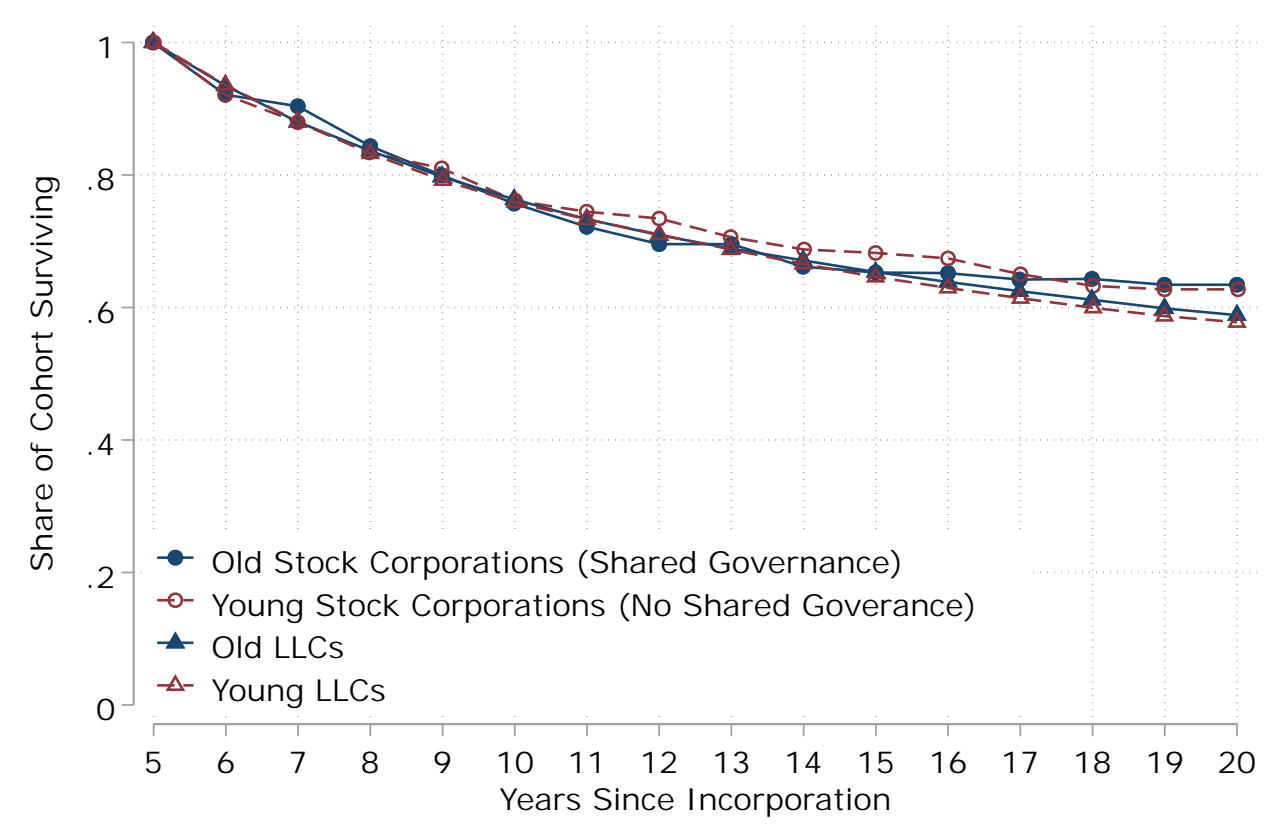

(b) Difference-in-Differences Estimates on Cumulative Exit and Bankruptcy

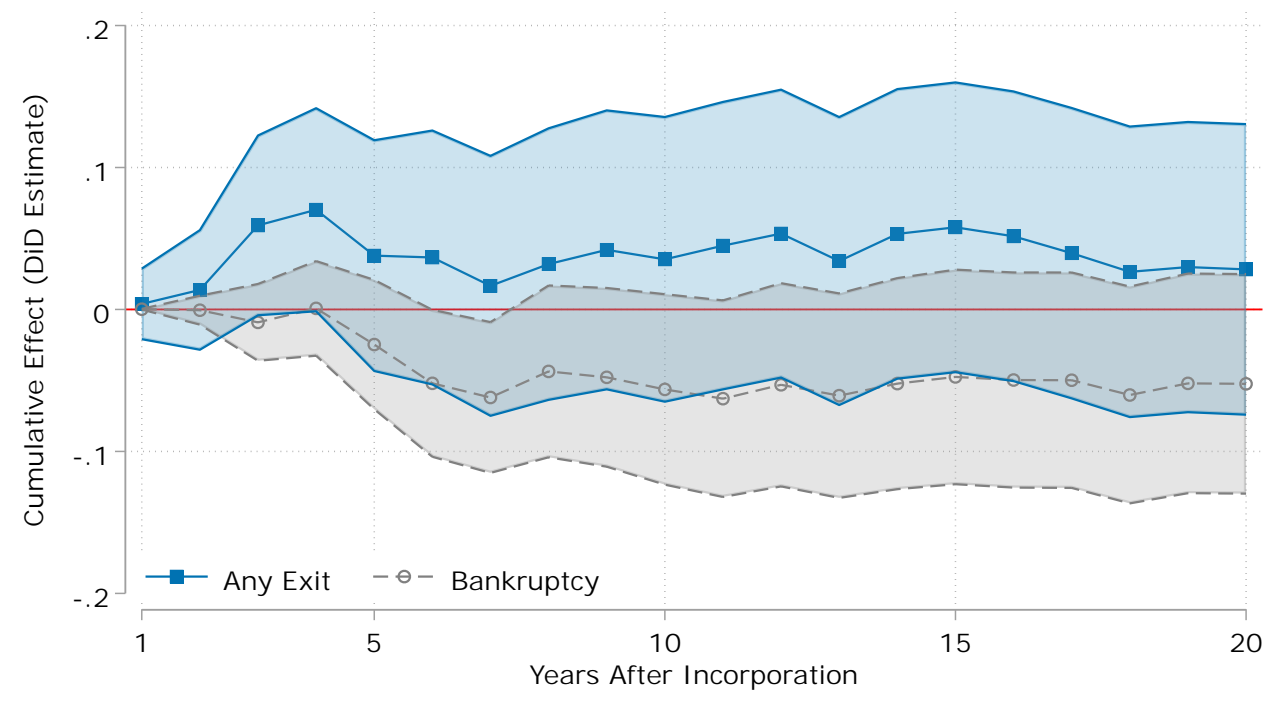

Note: The figure is based on the Mannheim Enterprise Panel. Panel (a) replicates Figure3 Panel (d) in showing the survival probability for firms incorporated within a two-year window of August 10, 1994. separately for firms incorporated before or after the cutoff date and for stock corporations and LLCs. Unlike Figure 3 Panel (d), this panel plots survival rates conditional on the firm being five years and older, to highlight the elimination of visible differences starting then. Panel (b) shows difference-in-differences point estimates and $95 \%$ confidence intervals for cumulative bankruptcy probabilities and for cumulative firm exit probabilities at various years after incorporation, showing that differences are small and statistically insignificant. 
Figure A.3: Effects on Labor Productivity and Capital Intensity

(a) Log Value Added per Worker

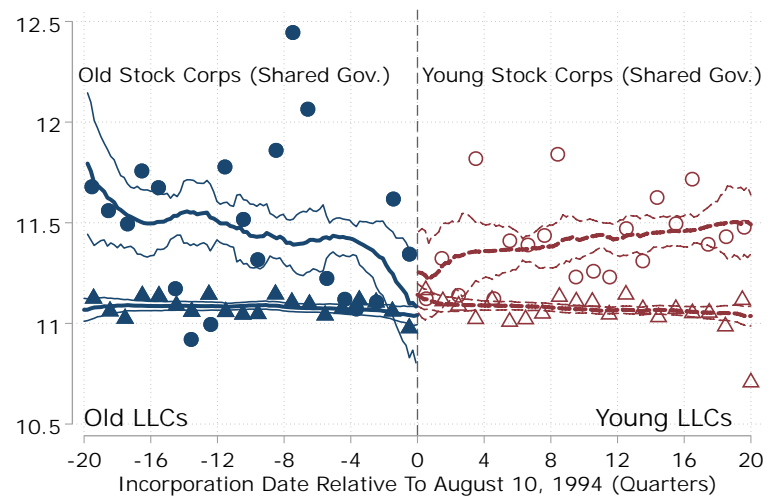

(c) Log Fixed Assets

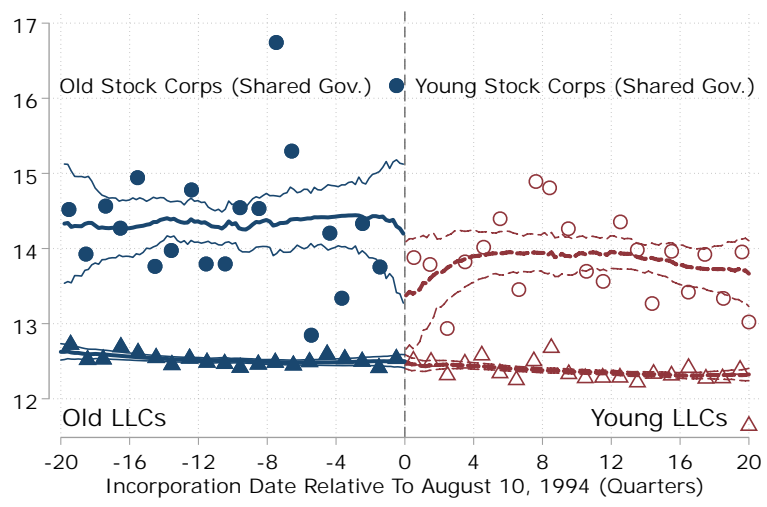

(e) Log Fixed Assets per Worker

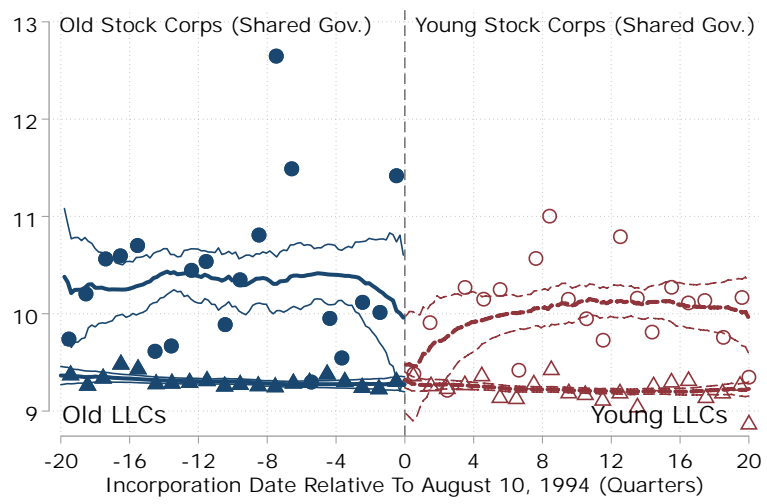

(b) Log Value Added per worker, DiD

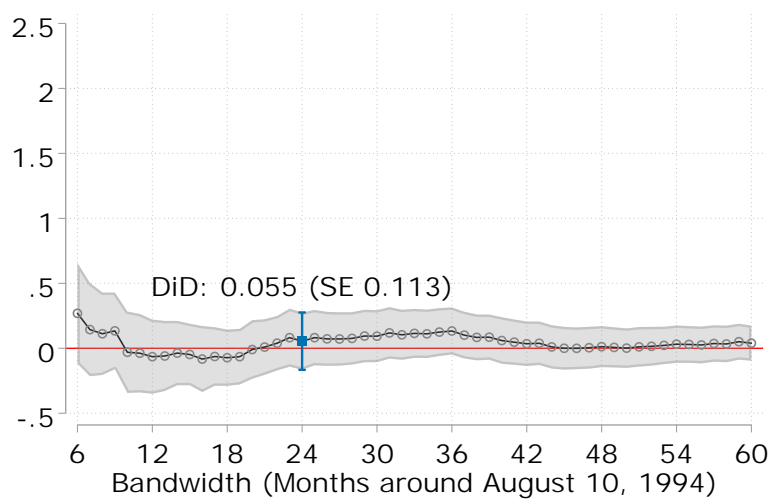

(d) Log Fixed Asset, DiD

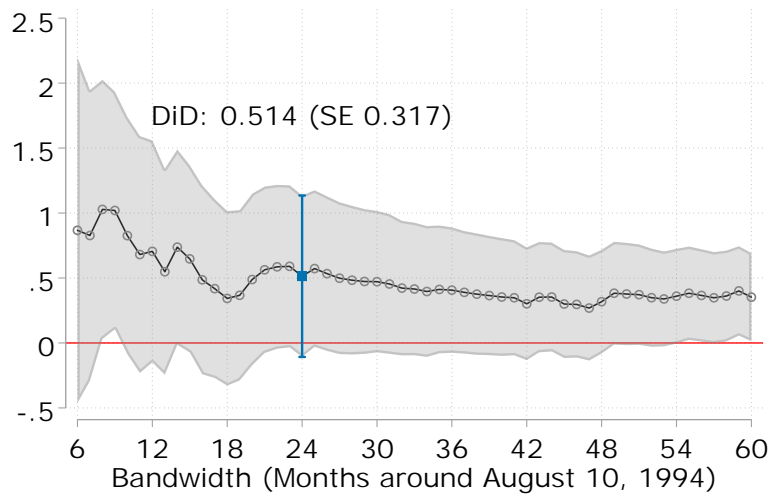

(f) Log Fixed Assets per Worker, DiD

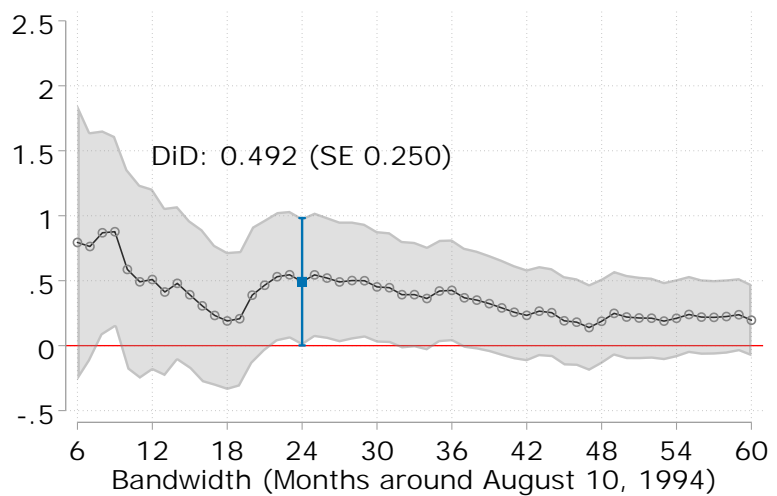

Note: The figure displays the effects of shared governance on firm-level labor productivity and capital. The left column presents binned scatter plots by quarter of incorporation date around the reform cutoff with a five-year bandwidth. It also plots results of a local linear regression with a uniform kernel and a two-year bandwidth, using day-specific incorporation date as the running variable. The right column plots coefficients and 95\% confidence intervals (with SEs clustered at the firm level) from difference-in-differences specifications with industry-year effects with varying bandwidths, reported on the x-axis. We report the corresponding main estimates, denoted by the highlighted blue square and blue $95 \%$ confidence intervals in Panels (b), (d) and (e), in Table 2 Columns (1), (7), and (9). We report our main graphical results in Figure 7. 
Figure A.4: Pooled Rent Sharing : Firms' Pay Premia (AKM Firm Fixed Effects) and Value Added per Worker

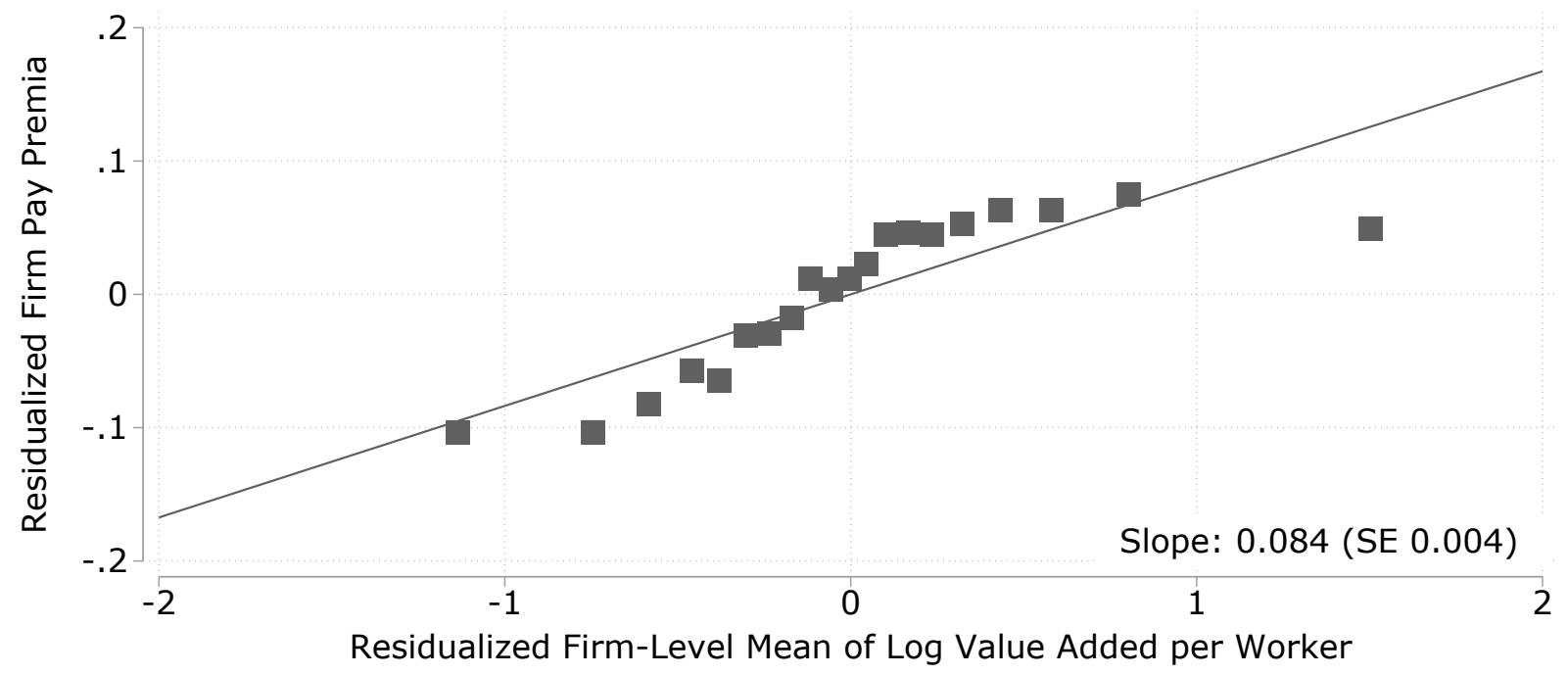

Note: This figure presents a binned scatter plots of firm's average pay premia (AKM firm fixed effects) plotted against average log value added per worker, in the 2006-14 sample of the Orbis-ADIAB data. The AKM firm fixed effects are estimated in a five-year rolling window and then averaged by firm. Both variables are residualized by industry (2-digit NACE) fixed effects. The figure also includes the estimated linear regression line, the slope of which we report in the bottom right along with standard errors. The sample consists of all firm-year observations in our analysis sample (LLCs and stock corporations) incorporated in a two-year bandwidth around the reform. 


\section{Theoretical Appendix: Hold-Up, Shared Governance, and Investment}

We now show that a simple but plausible extension that models worker participation as occurring also in bargaining over inputs, besides bargaining over wages, can overturn the underinvestment result of (Grout, 1984). Specifically, we separate the decisions in a model of sequential bargaining: rather than a unilateral firm decision, in stage 1 the firm and the workers now jointly determine the capital stock by bargaining. As in (Manning, 1987), on whom our application to shared governance draws, we permit the wage and investment bargaining to feature different worker bargaining power parameters, with $\iota$ applying to bargaining over investment:

$$
\max _{K}\left\{\iota \log S_{1}^{W}\left(w^{*}, \bar{L}, K\right)+(1-\iota) \log S_{1}^{F}\left(w^{*}, \bar{L}, K\right)\right\}
$$

where stage- 1 investment choices are again made anticipating wage rule (5), the structure of which remains unchanged in stage 2 . The worker and firm surpluses entering first-stage bargaining are $S_{1}^{W}=\bar{L} w^{*}-b \bar{L}$, while $S_{1}^{F}=F(K, \bar{L})-w^{*} \bar{L}-c K$. The previous case of the firm unilaterally setting capital is nested if $\iota=0$, when underinvestment emerged whenever $\phi>0$ and $c^{\prime}<c$. In that case, modeling shared governance as an increase in $\phi$ distorted investment further downward.

Indeed, the specific institution of codetermination gives workers a vote alongside capitalists in a series of corporate decisions, including those over strategically important investment decisions, and in the appointment and holding accountable of managers. Shared governance may therefore alternatively be viewed as an increase in $\iota$. To foreshadow why this channel will lead to higher rather than lower investment, note that here workers care about the capital choice $K$ solely because of its effect on wages. First consider the extreme case where workers have full bargaining power over inputs, i.e. $\iota=1$. The optimization problem (A.1) now maximizes worker surplus, $\max _{K}\left\{\log S_{1}^{W}\left(w^{*}, \bar{L}, K\right)\right\}$, with the following first order condition:

$$
\begin{aligned}
\bar{L} \frac{\partial w^{*}}{\partial K} & =0 \\
\Leftrightarrow \phi F_{K}\left(K^{*}, \bar{L}\right)-\phi c^{\prime} & =0 \\
\Leftrightarrow F_{K}\left(K^{*}, \bar{L}\right) & =c^{\prime} \leq c .
\end{aligned}
$$

Workers' capital choice trades off the benefit - its marginal product - of which share $\phi$ goes to the worker, with the marginal cost - resale value $c^{\prime}$ - because each unit of capital boosts the firm's outside option in form of $c^{\prime} K$ in wage setting. Workers ignore direct capital costs $c$. The two extreme cases of $\iota=0$ and $\iota=1$ make clear that increasing worker bargaining power in capital choice $\iota$ overturns the grout1984investment underinvestment result $\left(F_{K}>c\right)$ to overinvestment if $c^{\prime}<c$ (then $\left.F_{K}=c^{\prime}<c\right)$. 
The general bargained capital level $K^{*}$ under $\iota \in[0,1]$ is given by:

$$
F_{K}\left(K^{*}, \bar{L}\right)=c-\left(c-c^{\prime}\right) \times\left[\frac{(\iota-\phi)\left(F\left(K^{*}, \bar{L}\right)-b \bar{L}-c^{\prime} K^{*}\right)+\iota\left(c^{\prime}-c\right) K^{*}}{(1-\phi)\left(F\left(K^{*}, \bar{L}\right)-b \bar{L}-c^{\prime} K^{*}\right)+\iota\left(c^{\prime}-c\right) K^{*}}\right] .
$$

Here, $K^{*}$ depends on $\iota$ as follows:

$$
\frac{d K^{*}}{d \iota}=\frac{-\left(c-c^{\prime}\right)\left(F-b \bar{L}-c^{\prime} K^{*}+\left(c^{\prime}-F_{K}\right) K^{*}\right)}{(1-\phi)\left[F_{K K}\left(F-b \bar{L}-c^{\prime} K^{*}\right)+\left(F_{K}-c^{\prime}\right)^{2}\right]-\left(c-c^{\prime}\right)\left[F_{K}-c^{\prime}+\iota F_{K K} K^{*}\right]}
$$

This expression (which we formally evaluate in Appendix C.1) is positive, so $K^{*}$ is increasing in $\iota$, as long as $\phi>0$ and $c^{\prime}<c, 40$ If given a chance, workers will bargain to raise capital investment, as they will benefit in stage- 2 wage bargaining from the higher production. Hence, increasing worker bargaining power in operational decisions such as capital choices may mitigate hold-up and lead to efficient investment, and even overinvestment.

In sum, this extended model of labor-capital interaction serves as a proof of concept that a given institution boosting workers' control rights need not crowd out, and can in fact crowd in, investment.

\section{C.1 Comparative Statics of Investment to Bargaining Power Parameters $\phi$ and $\iota$}

We here formally derive the properties of the comparative static of capital stock choice $K^{*}$ to worker bargaining power parameters $\phi$ (in wage setting) and $\iota$ (in input choice).

Capital Choice In period 1, the objective function in the bargaining is:

$$
\max _{K}\left\{\iota \log S^{1 W}(\phi, \bar{L}, K)+(1-\iota) \log S^{1 F}(\phi, \bar{L}, K)\right\},
$$

where the surpluses of the parties depend on period 2 Nash bargaining: $S^{1 \mathrm{~W}}(\phi, \bar{L}, K)=$ $\phi S^{2}(K, \bar{L})$ and $S^{1 F}(\phi, \bar{L}, K)=(1-\phi) S^{2}(K, \bar{L})+\left(c^{\prime}-c\right) K$, with $S^{2}(K, \bar{L})=F(K, \bar{L})-b \bar{L}-c^{\prime} K$. 41

The optimality condition for $K$ is:

$$
\iota \frac{S_{K}^{1 W}}{S^{1 W}}+(1-\iota) \frac{S_{K}^{1 F}}{S^{1 F}}=0
$$

Where the subscript $K$ indicates the partial derivative of the function with respect to $K$. The second-order condition, a property we will use for the comparative statics below and

${ }^{40}$ If $\phi=0$ (i.e the workforce has no power in setting the wage), then $w^{*}=b$ does not depend on $K$. For $\iota=1$, any $K^{*}$ is a solution, while for $\iota<1$, efficiency emerges $\left(F_{K}=c\right)$.

${ }^{41}$ Period 2 Nash bargaining allocates surplus so that $S^{2 W}\left(w^{*}, \bar{L}, K\right)=\phi S^{2}(K, \bar{L})$ and $S^{2 F}\left(w^{*}, \bar{L}, K\right)=(1-$ $\phi) S^{2}(K, \bar{L})$. Period 1 and period 2 surpluses are related as follows: $S^{1 W}=S^{2 W}$ and $S^{1 F}=S^{2 F}+\left(c^{\prime}-c\right) K$. 
the value of which we define as $B$, is:

$$
\underbrace{\iota\left(\frac{S_{K K}^{1 W} S^{1 W}-S_{K}^{1 W} S_{K}^{1 W}}{S^{1 W} S^{1 W}}\right)+(1-\iota)\left(\frac{S_{K K}^{1 F} S^{1 F}-S_{K}^{1 F} S_{K}^{1 F}}{S^{1 F} S^{1 F}}\right)}_{\equiv B}<0 .
$$

The Effect of Worker Bargaining Power in Wage-Setting, $\phi$, on $K^{*}$ To characterize the effect of $K^{*}$ on $\phi$ totally differentiate first-order condition A.8 with respect to $K^{*}$ and $\phi$ in the neighborhood of $K^{*}$ :

$$
B \times d K^{*}+\underbrace{\left[\iota\left(\frac{S_{K \phi}^{1 W} S^{1 W}-S_{K}^{1 W} S_{\phi}^{1 W}}{S^{1 W} S^{1 W}}\right)+(1-\iota)\left(\frac{S_{K \phi}^{1 F} S^{1 F}-S_{K}^{1 W} S_{\phi}^{1 F}}{S^{1 F} S^{1 F}}\right)\right]}_{\equiv A} d \phi=0 .
$$

And therefore,

$$
\frac{d K^{*}}{d \phi}=\frac{A}{-B}
$$

By SOC A.9 , $-B>0$. We will now evaluate $A$ and hence the sign of $\frac{d K^{*}}{d \phi}$.

Note that

$$
\begin{array}{ll}
S^{1 W}=\phi S^{2} & S^{1 F}=(1-\phi) S^{2}+\left(c^{\prime}-c\right) K \\
S_{\phi}^{1 W}=S^{2} & S_{\phi}^{1 F}=-S^{2} \\
S_{K}^{1 W}=\phi S_{K}^{2} & S_{K}^{1 F}=(1-\phi) S_{K}^{2}+\left(c^{\prime}-c\right) \\
S_{K \phi}^{1 W}=S_{\phi K}^{1 W}=S_{K}^{2} & S_{K \phi}^{1 W}=S_{\phi K}^{1 F}=-S_{K}^{2} .
\end{array}
$$

Therefore

$$
S_{K \phi}^{1 W} S^{1 W}-S_{K}^{1 W} S_{\phi}^{1 W}=S_{K}^{2} \phi S^{2}-\phi S_{K}^{2} S^{2}=0
$$

(the first parenthesis in $A=0$ ). Recall also that from FOC $\left(\right.$ A.8), $\frac{S_{K}^{1 F}}{S^{1 F}}=-\frac{\iota}{1-\iota} \frac{S_{K}^{1 W}}{S^{1 W}}$. Note also 
that $S_{\phi}^{1 F}=-S_{\phi}^{1 W}$ and $S_{K \phi}^{1 F}=-S_{K \phi}^{1 W}$. Therefore, $A$ becomes:

$$
\begin{aligned}
A & =\left[\iota\left(\frac{S_{K \phi}^{1 W} S^{1 W}-S_{K}^{1 W} S_{\phi}^{1 W}}{S^{1 W} S^{1 W}}\right)+(1-\iota)\left(\frac{S_{K \phi}^{1 F} S^{1 F}-S_{K}^{1 F} S_{\phi}^{1 F}}{S^{1 F} S^{1 F}}\right)\right] \\
& =(1-\iota)\left(\frac{S_{K \phi}^{1 F}}{S^{1 F}}-\frac{S_{K}^{1 F}}{S^{1 F}} \frac{S_{\phi}^{1 F}}{S^{1 F}}\right) \\
& =-(1-\iota) \frac{S^{1 W}}{S^{1 F}}\left(\frac{S_{K \phi}^{1 W}}{S^{1 W}}+\frac{\iota}{1-\iota} \frac{S_{K}^{1 W}}{S^{1 W}} \frac{S_{\phi}^{1 W}}{S^{1 W}}\right) \\
& =-(1-\iota) \frac{S^{1 W}}{S^{1 F}}\left(\frac{1}{1-\iota} \frac{S_{K}^{2}}{S^{1 W}}\right) \\
& =-\left[\frac{S_{K}^{2}}{(1-\phi) S^{2}+\left(c^{\prime}-c\right) K}\right] \frac{(1-\iota) \phi S^{2}}{(1-\iota) \phi S^{2}} \\
& <0,
\end{aligned}
$$

provided that $\iota<1, \phi>0, S^{2}>0$.

Since $A<0$ and $-B>0$, we have now shown that

$$
\frac{d K^{*}}{d \phi}<0
$$

for any level of $\iota<1$, provided that $\phi>0$ and $S^{2}>0$.

The Effect of Worker Bargaining Power in Investment, $l$, on $K^{*}$ We totally differentiate FOC (A.8) with respect to $K^{*}$ and $\iota$ :

$$
B \times d K^{*}+\underbrace{\left[\frac{S_{K}^{1 W}}{S^{1 W}}-\frac{S_{K}^{1 F}}{S^{1 F}}\right]}_{\equiv C} d \iota=0 .
$$

so,

$$
\frac{d K^{*}}{d \iota}=\frac{C}{-B}
$$


Again by SOC $(A .9),-B>0$. We will now evaluate the sign of $C$, which determines the sign of $\frac{d K^{*}}{d \iota}$. Recall that from FOC $(\mathrm{A} .8), \frac{S_{K}^{1 F}}{S^{1 F}}=-\frac{\iota}{1-\iota} \frac{S_{K}^{1 W}}{S^{1 W}}$. Therefore, $C$ becomes:

$$
\begin{aligned}
C & =\left[\frac{S_{K}^{1 W}}{S^{1 W}}-\frac{S_{K}^{1 F}}{S^{1 F}}\right] \\
& =\left[\frac{S_{K}^{1 W}}{S^{1 W}}+\frac{\iota}{1-\iota} \frac{S_{K}^{1 W}}{S^{1 W}}\right] \\
& =\frac{1}{1-\iota} \frac{S_{K}^{1 W}}{S^{1 W}} \\
& =\frac{1}{1-\iota} \frac{\phi S_{K}^{2}}{\phi S^{2}} \\
& >0 .
\end{aligned}
$$

Since $C>0$ and $-B>0$,

$$
\frac{d K^{*}}{d \iota}>0
$$

for any level of $1>\phi>0$. If $\phi=0$, i.e workers have no power in setting the wage, then $w^{*}$ is equal to $b$ and does not depend on $K$. Therefore, for $\iota=1$ any $K$ is a solution, while for $\iota<1$ we have efficiency $\left(F_{K}=c\right)$ and $K^{*}$ does not depend on $\iota\left(\frac{d K^{*}}{d \iota}=0\right)$.

\section{C.2 Endogenous Labor}

Here, we relax the assumption of exogenous labor and assume instead that labor $L$ is chosen contemporaneously to $K$ with the same bargaining parameter $\iota$. If labor and capital are complements $\left(F_{L K}>0\right)$, the effects of changes in $\phi$ or $\iota$ on labor have the same signs as the respective effects on capital (and opposite for $F_{L K}<0$ ). Importantly, the model can therefore rationalize positive or neutral effects of increases in $\iota$ on labor.

The stage 1 objective function in Nash bargaining is now

$$
\max _{K, L}\left\{\iota \log S^{1 W}(\phi, K, L)+(1-\iota) \log S^{1 F}(\phi, K, L)\right\},
$$

where stage-2 surplus is anticipated to be Nash bargained as above. Note that $L$ only enters the surplus of the respective parties through aggregate period-2 surplus: $S^{1 W}(\phi, K, L)=$ $\phi S^{2}(K, L)$ and $S^{1 F}(\phi, K, L)=(1-\phi) S^{2}(K, L)+\left(c^{\prime}-c\right) K$, where $S^{2}(K, L)=F(K, L)-b L-c^{\prime} K$. Hence, both parties will agree on choosing the optimal level of $L$ regardless of bargaining powers, given by:

$$
\iota \frac{S_{L}^{1 W}}{S^{1 W}}+(1-\iota) \frac{S_{L}^{1 F}}{S^{1 F}}=0 \Leftrightarrow S_{L}^{2}\left[\iota \frac{\phi}{U}+(1-\iota) \frac{(1-\phi)}{V}\right] \Leftrightarrow S_{L}^{2}=0 \Leftrightarrow F_{K}=b .
$$


$L^{*}$ does not depend on $\phi$ or $\iota$ directly but only through $K$; for any change in $K, L^{*}$ adjusts such that $F_{L}(K, L)=b$ and hence:

$$
\frac{d L^{*}}{d K}=-\frac{F_{L K}}{F_{L L}}
$$

Moreover, the results (A.23) on $\frac{d K^{*}}{d \phi}<0$ and (A.31) on $\frac{d K^{*}}{d \iota}>0$ continue to hold in the case with endogenous $L$. The formulae (A.11) and (A.25) still hold, with $B$ now being a function of the Hessian of the objective function which we can again sign by appealing to the second order condition, 42

As a result, employment effects inherit the qualitative properties of the capital effects in this extended setting as long as $F_{L K}>0$. Going forward, we therefore consider the general setting with endogenous labor. Therefore, the results derived for capital effects with fixed labor above correspond to the partial effects $\frac{\partial K}{\partial \phi}=\frac{A}{-B}$ and $\frac{\partial K}{\partial \iota}=\frac{C}{-B}$ in the model with endogenous labor (with the seemingly fixed labor level set to the originally optimal one). However, the total capital effects $\frac{d K}{d \phi}=\frac{A}{-\tilde{B}}$ and $\frac{d K}{d \iota}=\frac{C}{-\tilde{B}}$ (while having the same sign as in the fixed-labor setting) also reflect endogenous adjustment in labor (with $\tilde{B}$ defined in Footnote 42.

The Effect of Worker Bargaining Power on $\frac{K}{L} \quad$ We further show that the capital-labor ratio will increase with $\iota$ as long as the capital-labor complementarity is not too large. These predictions will be qualitatively consistent with our empirical evidence. Related models with an insider/outsider perspective, in which worker representatives might advocate to keep employee numbers low in order to increase the capital-labor ratio and to reap ensuing rents as in lindbeck1989insider,johnson1990work, would predict a decline in employment - in contrast to our findings.

We now derive the additional comparative statics of profit and the capital labor ratio, and do so in the aforementioned extended model with endogenous labor. Denote the bargained capital-labor ratio by $R=\frac{K}{L}$. The effect of a parameter $\psi \in\{\phi, l\}$ on $R$ is:

$$
\begin{aligned}
\frac{d R}{d \psi} & =\frac{1}{L} \frac{d K}{d \psi}-\frac{K}{L^{2}} \frac{d L}{d \psi} \\
& =\frac{1}{L}\left[1+\frac{K}{L} \frac{F_{L K}}{F_{L L}}\right] \frac{d K}{d \psi},
\end{aligned}
$$

where the second equality uses A.34). The capital-labor ratio will move in the same

${ }^{42}$ To see this, take the total derivative of the FOCs (A.8) - now with endogenous labor - and (A.33) with respect to $L, K$ and the parameter of interest. Use the latter to replace $d L$ as a function of $d K$ in the former. This yields A.10) and (A.24, with $B$ being replaced by

$$
\tilde{B}=\left[\frac{\partial^{2} \Omega}{\partial L^{2}}\right]^{-1}\left[\frac{\partial^{2} \Omega}{\partial K^{2}} \frac{\partial^{2} \Omega}{\partial L^{2}}-\frac{\partial^{2} \Omega}{\partial K \partial L} \frac{\partial^{2} \Omega}{\partial L \partial K}\right]
$$

where $\Omega(K, L ; \phi, \iota)=\iota \log S^{1 W}(\phi, K, L)+(1-\iota) \log S^{1 F}(\phi, K, L)$ is the objective function of the bargaining. Note that $\tilde{B}<0$ by SOC. 
direction as capital, $\operatorname{sign}\left(\frac{d \frac{K}{L}}{d \psi}\right)=\operatorname{sign}\left(\frac{d K^{*}}{d \psi}\right)$, if and only if $F_{L K}<-\frac{L}{K} F_{L L}$, that is if the complementarity between $K$ and $L$ is not too large for the labor response (to the capital increase) to outpace the capital response. 


\section{Online Appendix References}

Goldschmidt, Deborah and Johannes Schmieder. 2017. "The Rise of Domestic Outsourcing and the Evolution of the German Wage Structure." The Quarterly Journal of Economics 132 (3):1165-1217.

Grout, Paul. 1984. "Investment and Wages in the Absence of Binding Contracts: A Nash Bargaining Approach." Econometrica 52 (2):449-460.

Manning, Alan. 1987. "An Integration of Trade Union Models in a Sequential Bargaining Framework." The Economic Journal 97 (385):121-139. 